UNIVERSIDADE DE SÃO PAULO

INSTITUTO DE GEOCIÊNCIAS

\title{
AVALIAÇÃO DE ÁREA CONTAMINADA POR COMPOSTOS ORGÂNICOS \\ ÀS MARGENS DA REPRESA DE GUARAPIRANGA, NO MUNICÍPIO DE SÃO PAULO - SP
}

Flávio Augusto Ferlini Salles

Orientador: Prof. Dr. Uriel Duarte

DISSERTAÇÃO DE MESTRADO

Programa de Pós Graduação em Recursos Minerais e Hidrogeologia

SÃO PAULO

1999 


\section{AVALIAÇÃO DE ÁREA CONTAMINADA POR COMPOSTOS ORGÂNICOS ÀS MARGENS DA REPRESA DE GUARAPIRANGA, NO MUNICÍPIO DE SÃO PAULO-SP}

FLÁVIO AUGUSTO FERLINI SALLES

Orientador: Prof. Dr. Uriel Duarte

DISSERTAÇÃO DE MESTRADO

COMISSÃO JULGADORA

Nome

Pressidente: Prof. Dr. Uriel Duarte

Examinadores:

Dr. Everton de Oliveira

Assinatura

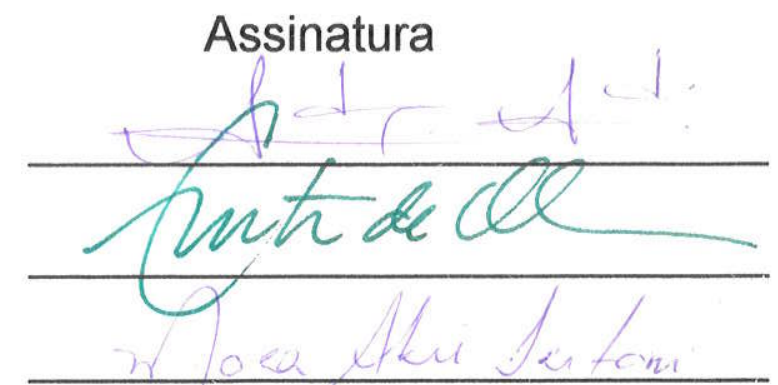

$\mathrm{Dr}^{\mathrm{a}}$ Mara Akie Iritani

SÃO PAULO

1999 
Índice

\section{ÍNDICE}

Índice de Tabelas

Indice de Figuras

Índice de Gráficos

Indice de Fotos

$v$

Fotos vi

Índice de Apêndices vii

Agradecimentos viii

Resumo 1

Abstract

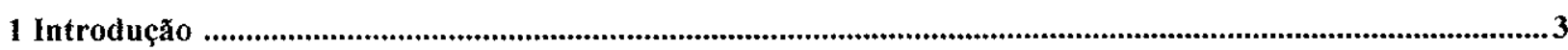

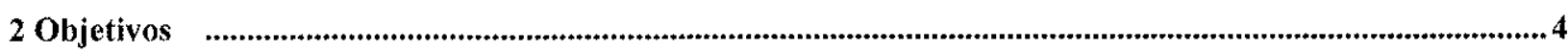

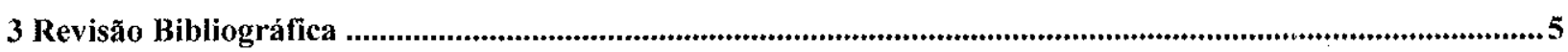

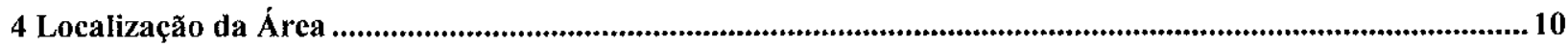

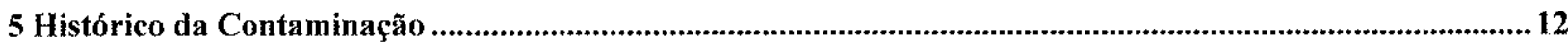

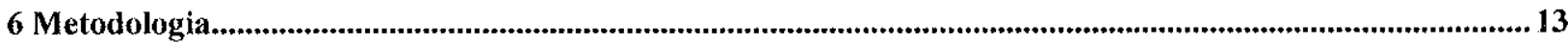

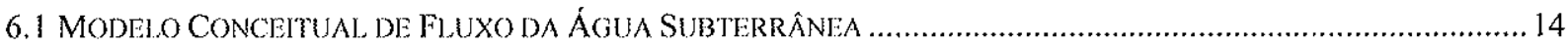

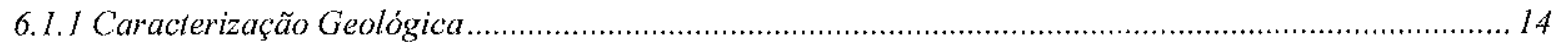

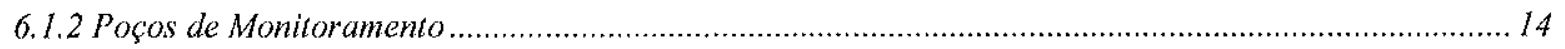

6.1.3 Determinação de Parâmetros Físicos do Solo ............................................................................ 15

6.1.4 Determinação da Condutividade Hidráulica.................................................................................

6.1.5 Determinação do Aporte de Água Subterrânea na Represa ............................................................. 19

6.1.6 Levantamento Planialtimétrico e Modelo Numérico de Terreno........................................................23

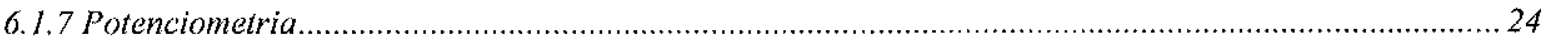

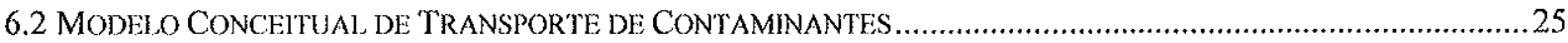

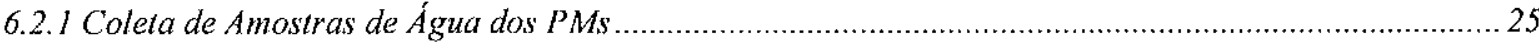

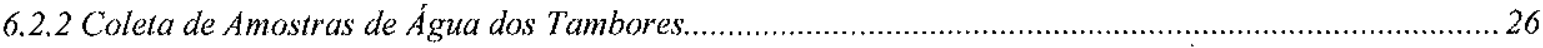

6.2 .3 Análises Quimicas de Amostras de Água .......................................................................26

6.2 .4 Interpretação das Plumas de Contaminação ..................................................................... 27

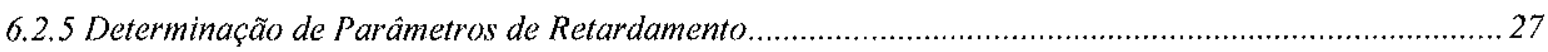

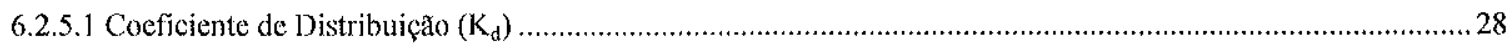

6.2.5.2 Coeficiente de Carbono Orgânico no Solo e $\left(\mathrm{K}_{\mathrm{oc}}\right)$ e Fração Orgânica de Carbono $\left(\mathrm{f}_{\mathrm{oc}}\right)$ no solo .......................29

6.2.6 Determinação do Fator de Retardamento ........................................................................29

6.2.7 Determinação da Velocidade de Deslocamento da Pluma de Contaminação...................................... 30 
7 Resultados Obtidos.

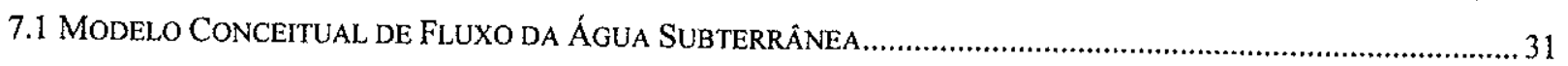

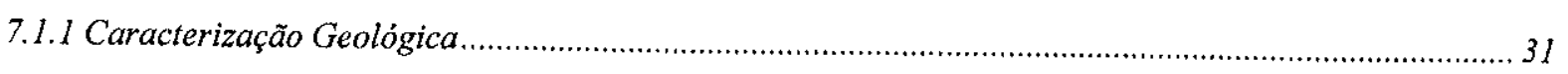

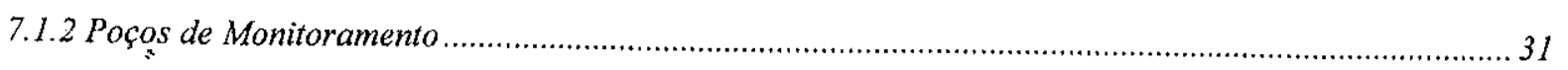

7.1.3 Determinação de Parâmetros Físicos do Solo ............................................................................... 34

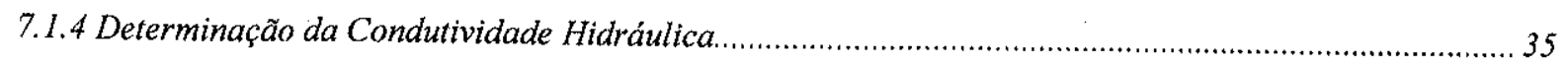

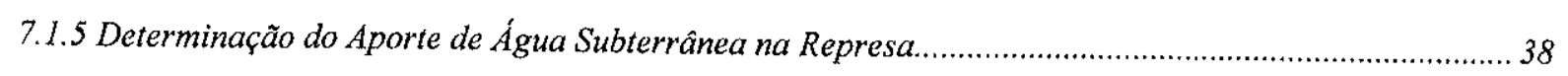

7.1.6 Levantamento Planialtimétrico e Modelo Numérico de Terreno .......................................................42

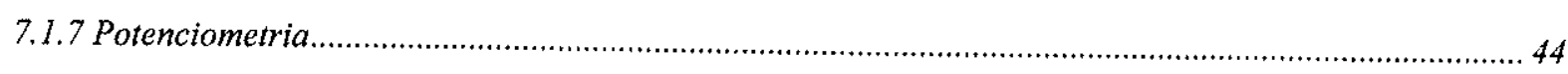

7.1.7.1 Cálculo da Velocidade de Fluxo da Água Subterrânea ...............................................................................48

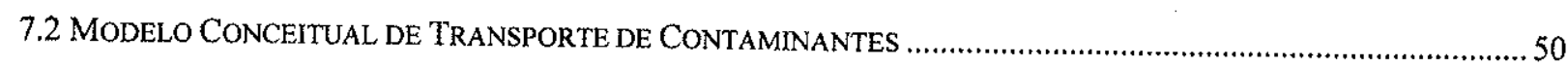

7.2.1 Análises Químicas de Amostras de Água....................................................................................5 50

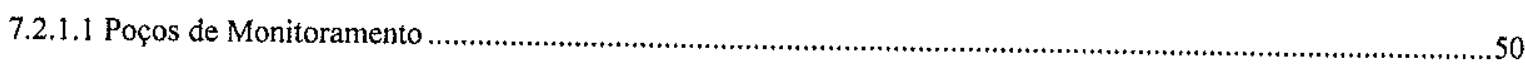

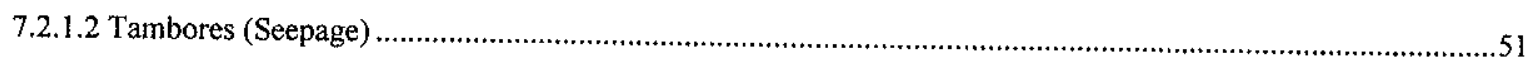

7.2 .2 Determinação das Plumas de Contaminação ............................................................................... 51

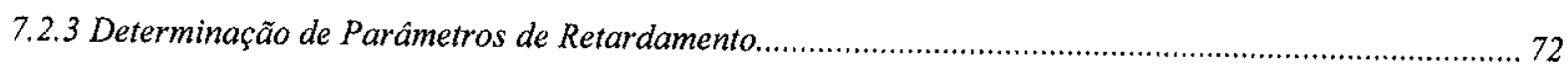

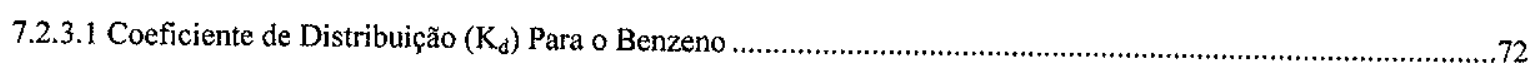

7.2.4 Determinação do Fator de Retardamento ....................................................................................... 73

7.2.5 Velocidade de Deslocamento das Plumas de Contaminação ............................................................75

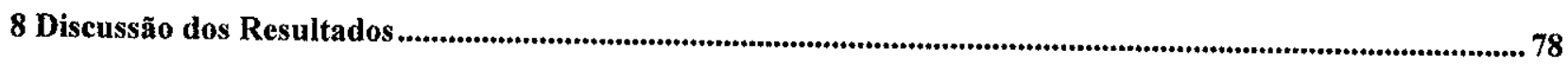

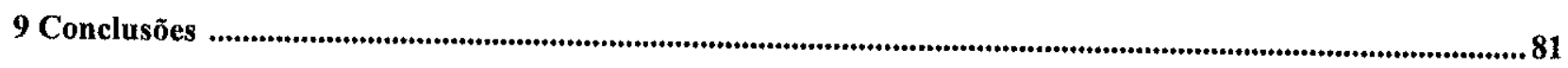

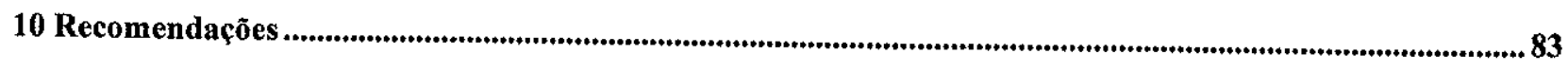

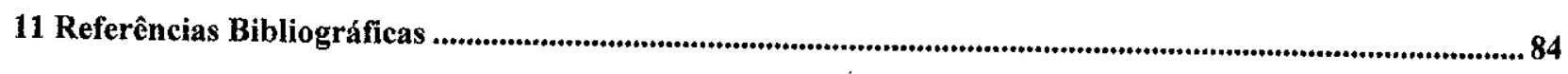




\section{ÍNDICE DE TABELAS}

Tabela 01 - Resultados dos Ensaios de Solo Realizados no IPT

Tabela 02 - Resultados dos Valores de Condutividade Hidráulica Obtidos dos Slug Tests.

Tabela 03 - Volumes Amostrados nos Testes do Tambor (Seepage)

Tabela 04 - Fluxo Calculado Para os Tambores Amostrados

Tabela 05 - Dados Físico-Químicos Para Determinação de $K_{d}$

Tabela 06 - Valores de $K_{d}$ calculados a partir de $f_{o c}$ e $K_{o c}$

Tabeia 07 - Fatores de Retardamento Calculados

Tabela 08 a - Velocidade de Deslocamento das Plumas de Contaminação. Velocidade Média da Água Subterrânea em 13/11/1997 .76

Tabela 08 b - Velocidade de Deslocamento das Plumas de Contaminação. Velocidade Média da Água Subterrânea em 16/05/1998 


\section{ÍNDICE DE FIGURAS}

\section{Figura 01}

Esquema das fases dos contaminantes LNAPLs no aquífero. fonte: Oliveira (1998)

Figura 02

Esquema das fașes dos contaminantes DNAPLs no aquifero. fonte: Oliveira (1998)

Figura 03

Mapa de Localização da Área

Figura 04 a

Zonas de recarga e descarga (modificado de Lee, 1978)

Figura 04 b

Modelo de descarga de água subterrânea em um lago ou estuário (modificado de Lee, 1978)

Figura 05

Esquema Simplificado do Equipamento Utilizado para o Teste Seepage (modificado de Lee, 1978)

\section{Figura 06}

Mapa de Localização dos PMs.

Figura 07

Gráficos de Slug Tests

Figura 07 (continuação)

Gráficos de Slug Tests

Figura 08

Mapa de Localização dos Tambores

Figura 09

Mapa Topográfico

Figura 10 a

MNT vista SE-NW

Figura 10 b

MNT vista SW-NE

Figura 11 a

Mapa Potenciométrico. Dados de 13 de novembro de 1997

Figura 11 b

Mapa Potenciométrico. Dados de 16 de maio de 1998

Figura 12 a

Mapa de Isoconcentrações. Benzeno. Dados de 21 de março de 1997

Figura $12 \mathrm{~b}$

Mapa de Isoconcentrações. Benzeno. Dados de 10 de dezembro de 1997

Figura 12 c

Mapa de Isoconcentrações. Benzeno. Dados de 16 de maio de 1998

Figura 13 a

Mapa de Isoconcentrações. Tolueno. Dados de 21 de março de 1997

Figura 13 b

Figura $13 \mathrm{c}$

Mapa de Isoconcentrações. Tolueno. Dados de 16 de maio de 1998 


\section{Figura $14 \mathrm{c}$}

Mapa de Isoconcentrações. Xilenos Totais. Dados de 16 de maio de 1998

Figura 15 a

Mapa de Isoconcentrações. 1,2 Dicloroetano. Dados de 21 de março de 1997

Figura 15 b

Mapa de Isoconcentrações. 1,2 Dicloroetano. Dados de 10 de dezembro de 1997

Figura $15 \mathrm{c}$

64

Mapa de Isoconcentrações. 1,2 Dicloroetano. Dados de 16 de maio de 1998

Figura 16 a

Figura $16 \mathrm{~b}$

Mapa de Isoconcentrações. 1,1,1 Tricloroetano. 10 de dezembro de 1997.

Figura $16 \mathbf{c}$

Mapa de Isoconcentrações. 1,1,1 Tricloroetano. Dados de 16 de maio de 1998

\section{ÍNDICE DE GRÁFICOS}

\section{Gráfico 01}

Determinação da Granulometria do Pré-Filtro

Gráfico 02

Determinação do Coeficiente de Distribuição $\left(K_{d}\right)$ 


\section{ÍNDICE DE FOTOS}

Foto 01

Vista da Represa de Guarapiranga a Partir da Indústria

\section{Foto 02}

Tambores Armazenados no Interior da Indústria

Foto 03

Tambores Utilizados no Teste Seepage

Foto 04

Fixação do Tambor T-03 na Represa

Foto 05

Amostragem de Água de Poço de Monitoramento

\section{Foto 06}

Tambor T-02 Instalado

Foto 07

Tambor T-05 Instalado 


\section{ÍNDICE DE APÊNDICES}

\section{APÊNDICE 01}

Perfis Construtivos dos Poços de Monitoramento

\section{APÊNDICE 02}

Medidas de Nivel D’Água e Determinação da Potenciometria Local

\section{APÊNDICE 03}

Velocidades Calculadas da Água Subterrânea

\section{APÊNDICE 04}

Análises Químicas para Determinação de Benzeno, Tolueno e Xilenos em Amostras dos PMs

\section{APÊNDICE 05}

Análises Quimicas para Determinação de Compostos Organoclorados em Amostras dos PMs

\section{APÊNDICE 06}

Análises Químicas para Determinação de Benzeno, Tolueno e Xilenos em Amostras dos Tambores

\section{APÊNDICE 07}

Análises Químicas para Determinação de Compostos Organoclorados em Amostras dos Tambores 


\section{Agradecimentos}

Agradeço à minha mãe, sem a qual não teria chegado sequer à metade do caminho.

Ao meu pai, muito mais perto e sempre presente.

Minha avó, Hilária, e Tia Claudete, o mais próximo que se pode chegar de sua mãe sem realmente sê-la.

Às já não tão pequeninas Maria Carolina e Paula.

À Carmem e à minha irmãzinha Mariana.

Aos grandes amigos Juliano e Vinicius, instaladores de tambores, amostradores de poços e modelos fotográficos.

Ao conselheiro Dalmo Ribas e ao parceiro Ricardo Filizzola.

Meus irmãos Marcelo Metralha Gramani, Fabiano Gardena Sambatti e Carlos Alberto Sivuca.

Primo Bedeto, mal sabe ele que a geologia veio lá de longe.

Ao professor e orientador Dr. Uriel Duarte.

Dr. Everton de Oliveira, por todo aprendizado hidrogeológico nestes últimos dois anos de convivência.

Celso Kolesnikovas, pela experiência e inestimável ajuda desde quando o projeto ainda estava no papel.

Aos senhores Djalma, Valdir e Alexandre Olio.

À HIDROPLAN - Hidrogeologia e Planejamento Ambiental S/C Ltda.

A Fapesp e Capes, por todo o apoio.

Ao Departamento de Geologia Sedimentar e Ambiental do Instituto de Geociências da Universidade de São Paulo.

A menininha Carolina Mi Wah Chow, pela presença na reta final. 


\section{Resumo}

Um acidente ocorrido há cerca de 20 anos propiciou a contaminação da água subterrânea por compostos orgânicos parcialmente misciveis tanto mais densos (DNAPL - Dense no Aqueous Phase Liquid) quanto menos densos (LNAPL - Light no Aqueous Phase Liquid) que a água em área próxima à represa de Guarapiranga.

Foram avaliadas as condições de fluxo da água subterrânea a partir da indústria até sua chegada na zona marginal da represa de Guarapiranga, sendo que o fluxo ascendente nesta zona foi determinado através do teste do tambor (Seepage). A amostragem de solo em sondagens permitiu a determinação de parâmetros físicos do aquífero, por análises laboratoriais, que em associação a dados determinados em campo, pela instalação de poços de monitoramento, permitiram calcular as velocidades de fluxo da água subterrânea entre $0,30 \mathrm{~cm} / \mathrm{dia}$ e $16,37 \mathrm{~cm} / \mathrm{dia}$. As diferentes velocidades de fluxo da água subterrânea são resultantes da variação dos gradientes hidráulicos condicionados pelo padrão topográfico e por eventuais heterogeneidades.

As plumas de Benzeno, Tolueno, Xilenos, 1,2 Dicloroetano e $1,1,1$ Tricloroetano estão limitadas à área da indústria, não tendo sido determinado aporte de contaminante na zona marginal da represa. Os fatores de retardamento impostos aos contaminantes durante o transporte pela água subterrânea foram determinados entre os 4,14 para clorofórmio e 55,30 para xilenos. Os valores estão relacionados à fração de carbono orgânico presente no solo, de 0,035 , calculada a partir da determinação do coeficiente de distribuição $\left(K_{d}\right)$ do Benzeno.

Os fatores de retardamento apresentam-se acima dos valores encontrados na literatura consultada. Como a literatura internacional apresenta parâmetros relacionados ao hemisfério norte, a maior presença de matéria orgânica no solo tropical avaliado pode explicar os elevados fatores de retardamento avaliados.

Estimou-se entre 26 anos (clorofórmio) e 454 anos (xilenos) o tempo de chegada dos contaminantes à represa. Como o acidente ocorreu há 20 anos, não há chegada de contaminantes na zona marginal da represa, fato comprovado pelas amostras de água dos tambores que não indicaram contaminação, permitindo desta forma a adoção de medidas preventivas de remediação. 


\section{Abstract}

The soil and groundwater underlying an industrial area close to the Guarapiranga Reservoir, in São Paulo, Brazil, were contaminated by light and dense non-aqueous phase liquid organic solvents (LNAPLs and DNAPLs) spilled from an accident.

The groundwater flow pattern for the area limited by the groundwater divider upgradient of the industry limits was determined by monitoring wells and by seepage tests for the discharge area at the border of the Guarapiranga Reservoir. The average linear velocity of the groundwater was estimated to be between $0,30 \mathrm{~cm} / \mathrm{dia} e$ $16,37 \mathrm{~cm} / \mathrm{dia}$ using slug tests and laboratory tests to determine physical parameters of the aquifer. This interval of velocities depends on local hydraulic gradients and heterogeneities.

The contaminant plumes of Benzene, Toluene, Xylenes, 1,2 Dichloroethane and 1,1,1 Trichloroethane are limited to the industry limits and no contaminant load was detected at the discharge area. Retardation factors were determined to be between 4.14 (chloroform) and 55.30 (xylenes) based on the organic carbon fraction obtained from the laboratory measured distribution coefficient $\left(K_{D}\right)$ for benzene. The retardation factor interval determined in this work is higher than the values usually found in literature, and this may be explained by higher organic content in tropical soils when compared to the northern hemisfere based values found in literature.

The expected average time interval for the arrival of contaminants to the Guarapiranga Reservoir was calculated to be 26 years for chloroform (minimum time interval) and 454 years for xylenes (maximum time interval). This fact was partially confirmed by the water samples collected from the seepage tests, were no contaminant load was found. 


\section{Introdução}

Este trabalho apresenta os resultados obtidos na caracterização hidrogeológica de área contaminada por compostos orgânicos às margens da represa de Guarapiranga, em São Paulo - SP.

O escopo do trabalho envolve a adoção de técnicas diversas relacionadas à ciência hidrogeológica visando reproduzir a real situação de contaminação da área avaliada.

A contaminação se dá tanto por compostos orgânicos mais densos quanto por compostos orgânicos menos densos que a água subterrânea.

As medidas adotadas para caracterização da área selecionada não encerram todas as possibilidades técnicas disponiveis à execução do trabalho proposto, mas sim constituem uma metodologia de trabalhos que pode ser adaptada e reutilizada em áreas similares.

Os trabalhos de caracterização da área visam quantificar a contaminação presente em solo e água subterrânea e o aporte de contaminantes na zona marginal da represa de Guarapiranga. 


\section{Objetivos}

O objetivo fundamental deste trabalho é o de apresentar:

- metodologia prática para avaliação de área contaminada por compostos orgânicos;

- caracterização de fluxo de água subterrânea em corpo d'água superficial situado à jusante da área contaminada;

- metodologia de estudo de contaminação em água subterrânea por compostos menos densos e mais densos que a água;

- aplicação de técnicas de campo adaptadas à situação específica estudada, tanto para avaliação da área contaminada, quanto para determinação do aporte de contaminantes na represa;

- métodos de interpretação dos dados obtidos em campo para configuração do modelo conceitual de fluxo e transporte dos contaminantes;

- método para monitoramento do aporte de contaminantes em corpos d'água superficiais. 


\section{Revisão Bibliog ráfica}

Não há uma receita infalivel que permita a caracterização de qualquer cenário de contaminação, mas sim, técnicas individuais que constituem importantes ferramentas de trabalho e permitem, quando em conjunto, a visualização global do ambiente contaminado e a consequente adoção de medidas para avaliação dos riscos associados a tal contaminação. As formas de contaminação definem a metodologia a ser adotada para a avaliação do meio contaminado.

Freeze and Cherry (1979) apresentam dados referentes ao ano de $1997 \mathrm{da}$ USEPA (United States Environmental Protection Agency), mostrando que, naquele pais, em torno de 17 milhões de áreas de disposição de rejeitos forneciam aos aquíferos mais de 6,5 bilhões de metros cúbicos de contaminantes reais ou potenciais.

No Brasil, Oliveira (1992) apresenta dados referentes ao ano de 1987, do extinto Conselho Nacional do Petróleo, que indicavam a existência de 1.618 postos de abastecimento de combustiveis no pais, os quais possuiam capacidade de armazenamento total da ordem de 358 milhões de litros, constituindo potenciais fontes de contaminação de solo e/ou águas subterrâneas. Uma situação tipicamente urbana é abordada no trabalho de Kolesnikovas (1997), que caracteriza os riscos representados por contaminações derivadas de vazamentos em postos de abastecimento nas proximidades de linhas do metrô na cidade de São Paulo. Os autores discorrem sobre a avaliação de áreas contaminadas por hidrocarbonetos derivados de petróleo e em suas obras é possivel identificar as dificuldades de caracterizar áreas urbanas contaminadas, fundamentalmente pelo difícil acesso à informações diretas provenientes de sondagens e poços de monitoramento e pela existência de interferências subterrâneas (cabos telefônicos, tubulações de água, gás e esgoto, galerias de águas pluviais, fundações, etc.) que dificultam a execução de sondagens e ainda podem influir no regime de fluxo da água subterrânea e transporte de contaminantes em subsuperfície. 
A detecção de eventuais contaminações em áreas urbanas, por vezes, se dá pelo surgimento de contaminantes em poços públicos de abastecimento (Freeze and Cherry, 1979) ou em outros pontos de surgência de indícios diversos de contaminaçẵo, tais como garagens subterrâneas de edificios, porões de residências, poços de captação de água subterrânea domiciliares, etc.

Em meios urbanos, problemas derivados do armazenamento de combustiveis e solventes diversos, em postos de abastecimento e indústrias, constituem importantes fontes de contaminação de solo e águas subterrâneas.

As características dos contaminantes definem, juntamente com o meio a ser avaliado, as técnicas a serem empregadas para caracterização do cenário de contaminação.

O conhecimento da distribuição dos contaminantes nas diversas formas que podem assumir ao longo do seu trajeto pelo aquífero, deste a fonte de contaminação até a água subterrânea, determina os métodos a serem adotados para controle da situação e redução da contaminação para níveis aceitáveis à preservação da saúde humana.

Testes controlados de campo executados por Barker et al (1989), no qual concentrações conhecidas de contaminantes foram injetadas no aquífero $e$ posteriormente monitoradas através de malha de poços, apresentam o comportamento básico dos hidrocarbonetos aromáticos, notadamente conhecidos como BTEX, abreviação dos compostos Benzeno, Tolueno, Etilbenzeno e dos três isômeros (orto, meta e para) do Xileno. Kueper et al (1989), por sua vez, realizaram trabalhos laboratoriais adotando colunas de sedimentos para determinar o comportamento de solventes organoclorados em meios porosos heterogêneos.

Os contaminantes avaliados nos dois trabalhos constituem dois grandes grupos com comportamentos distintos nos aquíferos, ambos semelhantes no fato de serem parcialmente miscíveis em água, porém diferenciando-se no fato de serem, os primeiros (BTEX), menos densos que a água e, os segundos (organoclorados) mais densos. 
A migração do contaminante em fase dissolvida constitui o principal meio de expansão da pluma de contaminação, porém, para os compostos ditos parcialmente imiscíveis em água (NAPLs - non aqueous phase liquid ou fase líquida não aquosa), a fase dissolvida engloba o menor volume de contaminante, conforme a relação apresentada por Groundwater Technology Inc. (1983) em Oliveira (1992), na qual pode ser observado que, de um vazamento de hidrocarbonetos aromáticos a partir de tanque de armazenamento subterrâneo de combustíveis, por exemplo, $62 \%$ do volume total de contaminantes correspondem à fase livre imiscível, $33 \%$ correspondem à fase sorvida e apenas $5 \%$ correspondem à fase dissolvida. No entanto, a partir do mesmo vazamento, a distribuição em termos de volume contaminado apresenta a parcela de $1 \%$ atribuída à fase livre imiscivel de contaminante, $20 \%$ à fase sorvida e $79 \%$ à fase dissolvida.

De acordo com o trabalho do CCME - Canadian Council of Ministers of the Environment (1994), os compostos parcialmente miscíveis (NAPLs) avaliados nesta dissertação podem se apresentar, a partir do vazamento, em fase de vapor na zona não saturada do aquífero, em fase residual adsorvida ao solo, em fase dissolvida na água subterrânea, e em fase livre imiscivel distribuída sobre a franja capilar no caso dos compostos menos densos que a água (LNAPL Light Non Aqueous Phase Liquid ou

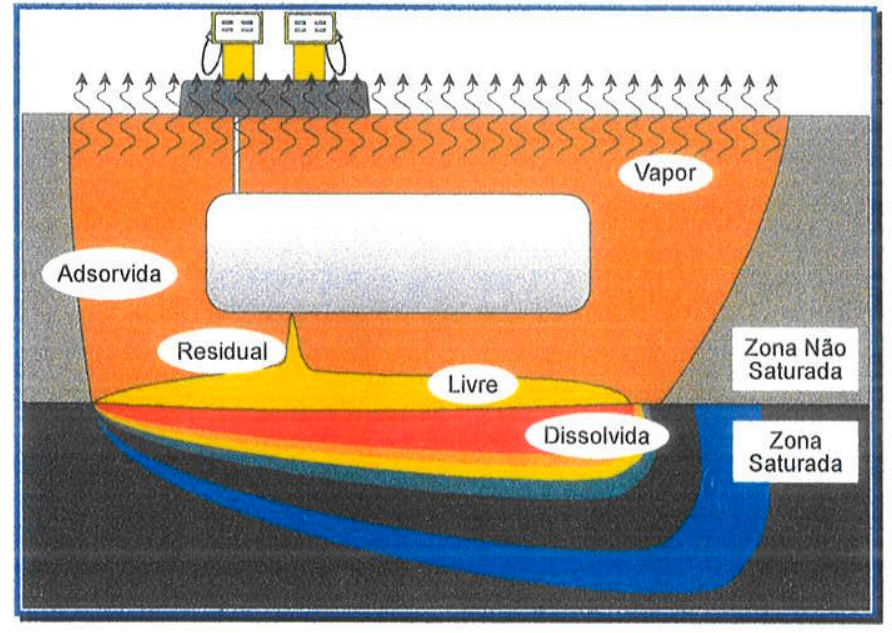

Figura 01 Esquema das fases dos contaminantes LNAPLs no aquífero. fonte: Oliveira (1998)

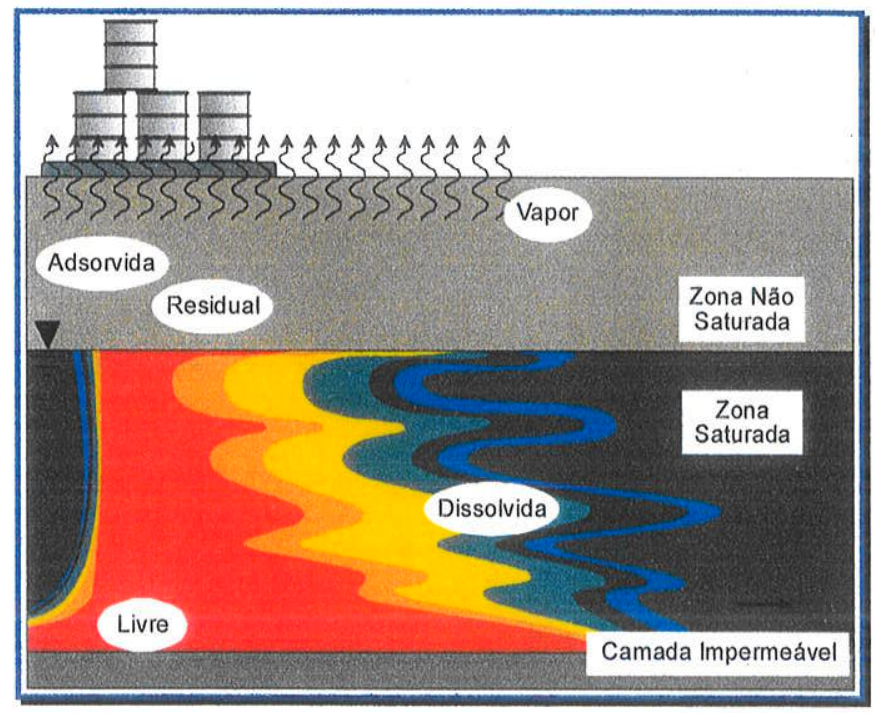

Figura 02 Esquema das fases dos contaminantes DNAPLs no aquífero. fonte: Oliveira (1998) 
fase líquida não aquosa leve), como apresentado na Figura 01 (Oliveira, 1998), e sob a franja capilar, em "piscinas" sustentadas por camadas impermeáveis, caso dos compostos mais densos que a água (DNAPL - Dense Non Aqueous Phase Llquid ou fase líquida não aquosa densa), conforme apresentado na Figura 02 (Oliveira, 1998).

A geração do sistema multifásico, constituído pela presença da água e de mais de um contaminante com comportamentos distintos, impõe ao hidrogeólogo a necessidade de adotar mais de uma técnica de avaliação para caracterizar adequadamente o cenário de contaminação proposto.

O transporte dos contaminantes orgânicos mais ou menos densos que a água é regido pelo sistema de fluxo da água subterrânea, consistindo o processo advectivo em função dos parâmetros intrínsecos que constituem o meio poroso avaliado, tais como condutividade hidráulica, porosidades total, específica para fluxo e de retenção, densidade dos grãos, heterogeneidades, anisotropias, etc.

Uma vez relacionado ao regime de fluxo freático, os contaminantes transportados em fase livre ou dissolvida podem chegar a atingir corpos d'água superficiais que venham a constituir zonas de descarga.

Lee (1978) apresenta metodologia denominada Seepage, ou teste do tambor, que permite avaliar o fluxo vertical de água subterrânea em corpo d'água superficial, permitindo ainda a coleta de amostras de água para análises químicas e verificação do eventual aporte de contaminantes no corpo d'água de interesse. $O$ teste proposto por Lee (1978) constitui um método pouco oneroso para avaliação de contaminações em zonas marginais de corpos d'água superficiais, necessitando de materiais de fácil acesso (seção de tambor metálico comum e tubos plásticos para coleta de amostras) e podendo ser aplicado com obtenção resultados em períodos relativamente curtos (dependentes das características do meio poroso avaliado) e considerável precisão dos resultados (capacidade de medição de $0,001 \mathrm{~cm}^{3} / \mathrm{m}^{2}$ s, segundo o autor)

Variações locais na velocidade de fluxo da água subterrânea podem ocasionar atenuação na velocidade de transporte de contaminantes por dispersão mecânica, assim como o gradiente de concentrações dos contaminantes em regimes de fluxos de baixa velocidade podem ocasionar dispersão do soluto por difusão molecular. 
Fetter (1988) define como reativos os compostos que podem sofrer retardamento na velocidade de transporte por efeito de reações químicas, biológicas ou decaimento radiativo.

No caso de compostos orgânicos, o retardamento na velocidade de transporte é um fator diretamente relacionado à fração de carbono orgânico presente no meio poroso avaliado. A afinidade do contaminante estudado com o carbono orgânico presente no meio poroso promove a" sorção do contaminante, ou seja, a partição do composto em fase dissolvida na água subterrânea e posterior aderência à partículas do meio sólido ao redor, em reação reversivel.

A partição do composto entre o mejo aquoso e o meio poroso ao redor é determinada através de Batch Test, no qual o composto de interesse é dissolvido em água e posteriormente adicionado à várias amostras do meio poroso a ser avaliado. $\mathrm{A}$ razão entre a concentração final do contaminante no solo pela concentração final do contaminante na água após a passagem pelo meio poroso representa o coeficiente de distribuição $\left(K_{d}\right)$ para este no meio específico.

Diretamente relacionado ao $K_{d}$ encontra-se o Fator de Retardamento $\left(F_{r}\right)$, conforme apresentado na Equação 09 (página 30). 


\section{Localização da Área}

A área de estudos está localizada na zona sul do município de São Paulo, no bairro de Santo Amaro.

O perímetro da indústria química alvo das investigações hidrogeológicas é limitado à sul e a leste pela estrada de Jaceguava, a qual margeia a represa de Guarapiranga.

A Figura 03 apresenta o local de estudos, com coordenadas arbitrárias atribuídas durante os trabalhos de levantamento planialtimétrico da área.

Figura 03 - Mapa de Localização da Área

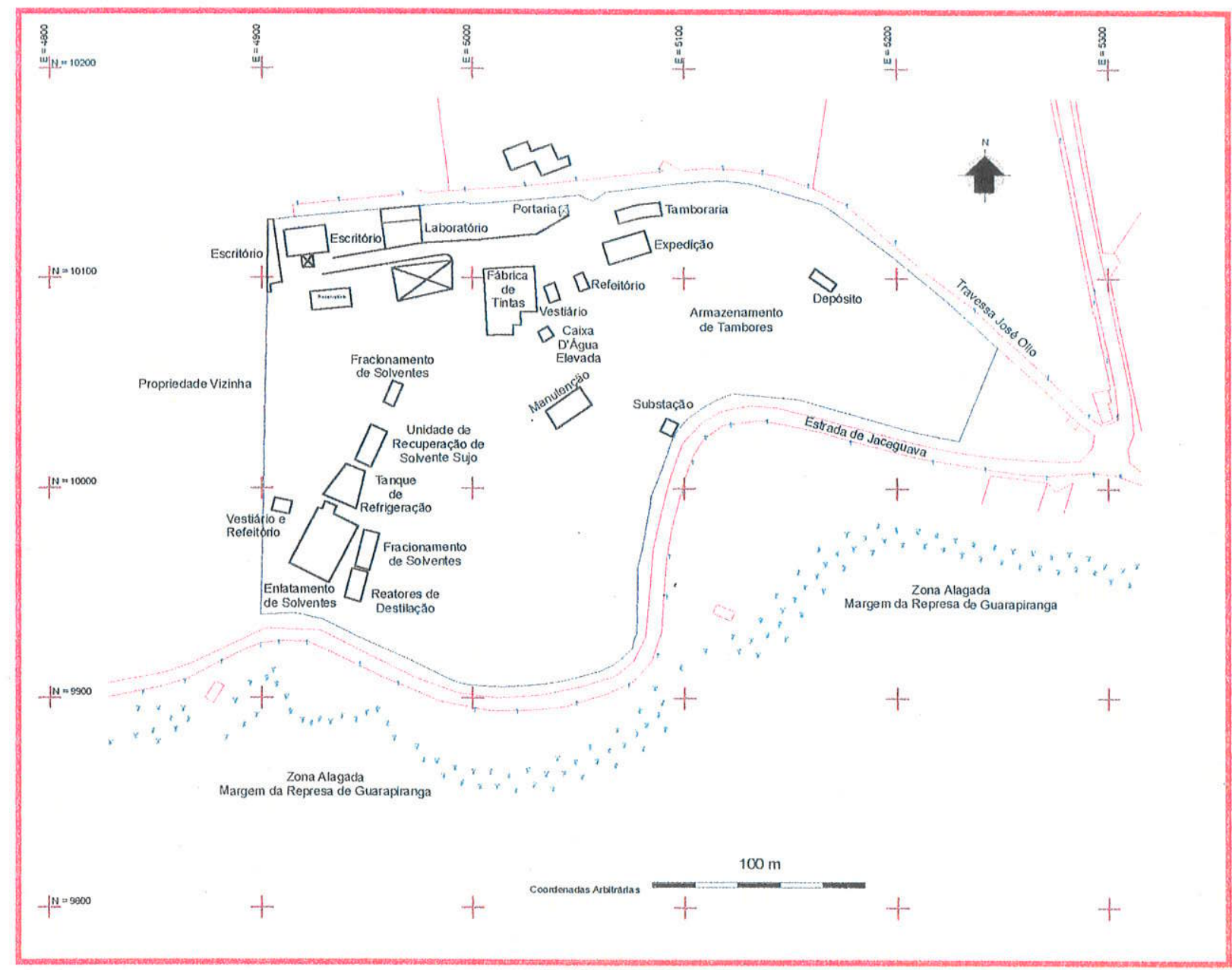


A Foto 01 apresenta vista da represa de Guarapiranga com sentido sudeste a partir da indústria onde foi identificado o cenário de contaminação. É possível observar a presença de lâmina d'água na represa na porção centro-leste da Foto 01, estando a maior parte da foto representada por densa cobertura vegetal.

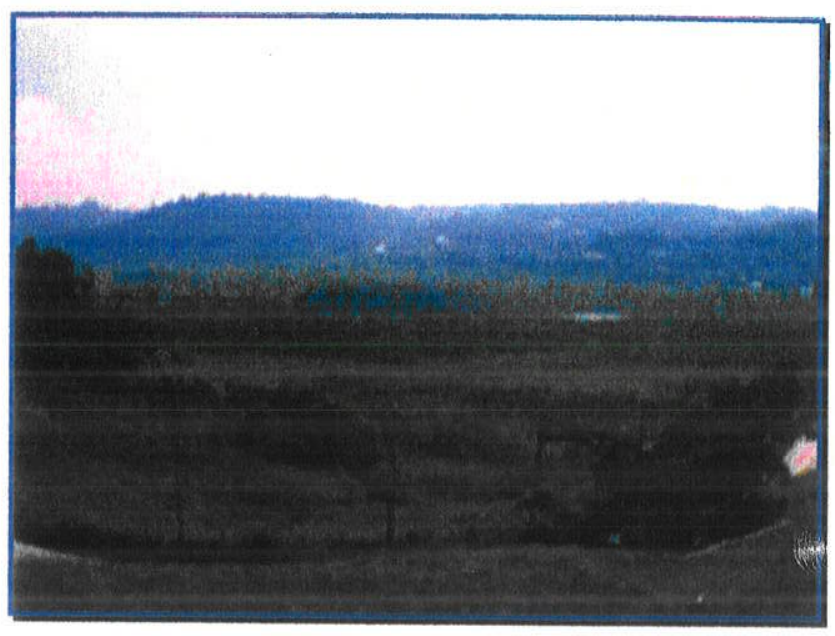

Foto 01 Vista da represa a partir da indústria 


\section{Histórico da Co ntaminação}

A área avaliada foi afetada por acidente em indústria química que desenvolve atividades relacionadas à fabricação de tintas destinadas ao mercado automotivo, empregando no processo de produção solventes diversos contendo hidrocarbonetos derivados de petróleo e organoclorados.

Este acidente ocorreu há cerca de 20 anos, quando, por motivos não esclarecidos, um incêndio ocorrido na fábrica de tintas (Figura 03) ocasionou uma explosão que possibilitou a infiltração de quantidade não estimada de solventes no solo não impermeabilizado.

À época, além do acidente, práticas de armazenamento de tambores (Foto 02) contendo resíduos de solventes em áreas não impermeabilizadas e expostas à intempéries, constituíam possiveis fontes de contaminação de solo e/ou água subterrânea.

Como terceira fonte de contaminação, foram notificados derramamentos acidentais de

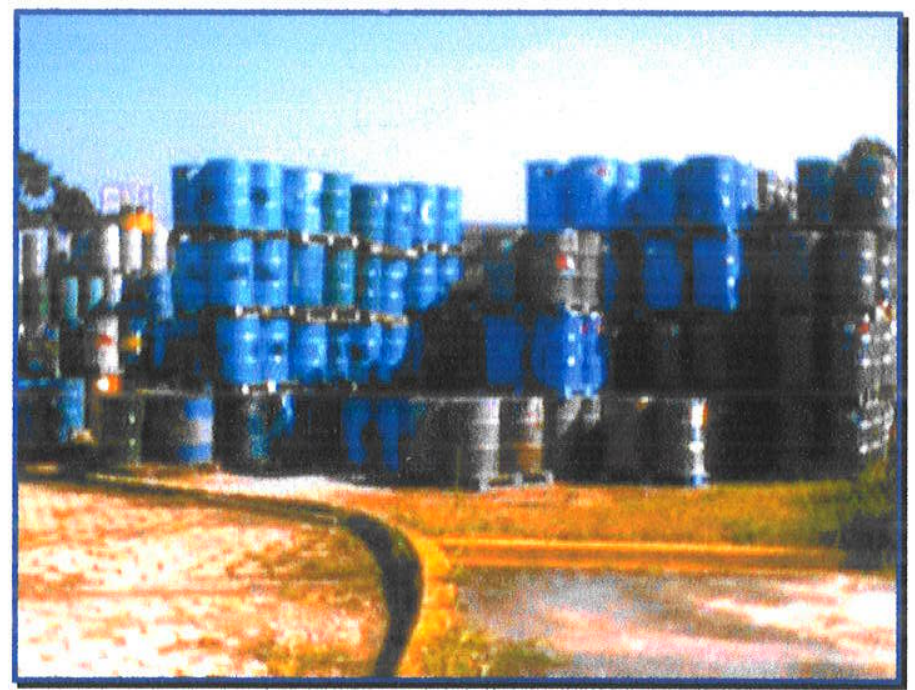

Foto 02 Tambores armazenados produto na porção jusante da indústria, nas proximidades do tanque de refrigeração, área na qual são efetuados trabalhos de recuperação de solventes. O manuseio de produto ocasionou perdas acidentais de pequenos volumes que migraram pelas canaletas de contenção existentes nas proximidades para o exterior da indústria, eventualmente atingindo a zona que margeia a represa.

Pelo fato de não se conhecer a composição do produto derramado dos tambores e tampouco do produto derramado no solo no acidente, foram selecionados compostos de interesse ambiental representativos para delimitação da pluma de contaminação no local, de acordo com a composição dos solventes utilizados em indústrias similares. 


\section{Metodologia}

A metodologia aplicada no trabalho foi dividida em duas grandes etapas distintas, de forma a possibilitar melhor organização dos dados e apresentação lógica dos resultados obtidos.

Desta forma, considerou-se como o modelo conceitual de fluxo da água subterrânea a etapa inicial na qual foram determinados parâmetros relacionados ao aquífero e efetuados trabalhos visando a caracterização geológica e hidrogeológica da área de estudos. Inserem-se nesta etapa as atividades relacionadas à determinação de parâmetros físicos do meio poroso estudado, bem como a realização de entrevistas com trabalhadores da indústria (área fonte de contaminação) e avaliação de dados topográficos e geomorfológicos para formulação de modelo conceitual de fluxo da água subterrânea visando a instalação dos poços de monitoramento do aquífero freático e de tambores para determinação do fluxo ascendente de água subterrânea no corpo d'água superficial situado a jusante.

$\mathrm{Na}$ segunda etapa foi determinado o modelo conceitual de transporte dos contaminantes, tendo sido consideradas a informações obtidas através de análises químicas e características dos contaminantes de interesse selecionados previamente.

A determinação de parâmetros específicos dos contaminantes, influentes nos processos de transporte, em associação aos dados obtidos na primeira etapa, tiveram por finalidade a confecção do modelo conceitual de transporte, do qual esperávamos obter informações referentes ao tempo de migração das plumas de contaminação, à distribuição das plumas dentro da área de estudos e com relação ao corpo d'água superficial a jusante. 


\subsection{Modelo Conceitual de Fluxo da Água Subterrânea}

\subsubsection{Caracterização Geológica}

A geologia da área estudada foi determinada a partir de consulta ao mapeamento realizado pelo Instituto de Pesquisas Tecnológicas do Estado de São Paulo (1995), em correlação aos dados obtidos das sondagens realizadas com a finalidade de instalação de poços de monitoramento do aquífero freático.

Durante a realização das sondagens, amostras foram coletadas para caracterização do solo local.

\subsubsection{Poços de Monitoramento}

Visando o acompanhamento das alterações relacionadas ao aqüifero freático em sua zona saturada, foram instalados 33 Poços de Monitoramento (PMs).

A instalação dos PMs seguiu as orientações presentes na norma da Associação Brasileira de Normas Técnicas (ABNT), NBR 13.895, sofrendo adaptações de acordo com as características do meio avaliado.

As perfurações para instalação dos PMs foram executadas através da utilização de trado mecanizado, com concha possuindo diâmetro interno útil de $25,4 \mathrm{~cm}$ ou 10 " (dez polegadas). A profundidade das sondagens variou de acordo com a presença, em subsuperficie, de litologia impenetrável ao equipamento de perfuração utilizado, objetivando a instalação de PMs totalmente penetrantes (Cleary, 1989), de forma a propiciar o monitoramento de compostos orgânicos mais densos que a água subterrânea. Tubulação em PVC inerte, com diâmetro interno útil de $10,16 \mathrm{~cm}$ ou 4" (quatro polegadas), foi utilizada para revestimento das sondagens.

O filtro, constituído por tubulação de PVC inerte, também com diâmetro interno útil de $10,16 \mathrm{~cm}$ ou 4" (quatro polegadas), possui ranhuras transversais, com diâmetro de $0,50 \mathrm{~mm}$, inferiores às da norma NBR 13.895 para impedir o bloqueio por partículas finas do solo argiloso constituinte do aquífero estudado. 
O espaço anelar formado entre as paredes do revestimento e da sondagem foi preenchido por pré filtro, sendo a granulometria compatível com a do solo perfurado, de acordo com a relação expressa por Terzaghi (1940), que define a faixa de material filtrante obedecendo a Equação 01:

$$
m D 15_{(\text {solo })}\left\langleD 1 5 _ { ( \text { filtro } ) } \left\langle n D 85_{(\text {solo })}\right.\right.
$$

onde,

D15 = diâmetro no qual $15 \%$ dos grãos passam pela peneira

D85 = diâmetro no qual 85 \% dos grãos passam pela peneira

$m$ e $n=$ fator de segurança

O pré-filtro com menor granulometria visa o não carreamento de partículas e, consequentemente, impede o fechamento das ranhuras do filtro. $O$ pré-filtro com maior granulometria, por sua vez, visa fornecer uma maior condutividade hidráulica com relação ao meio poroso ao redor, facilitando a migração de água subterrânea e de eventuais contaminantes presentes no aquifero.

As bocas dos PMs foram protegidas por cap rosqueável contendo cadeado e, ao seu redor, foi construída estrutura em concreto dotada de tampa metálica, de forma a evitar sua destruição acidental.

\subsubsection{Determinação de Parâmetros Fisicos do Solo}

Amostras de solo foram coletadas dos PMs 08 e 14 e analisadas no Laboratório de Física do Solo, do Agrupamento de Geologia Aplicada ao Meio Ambiente, da Divisão de Geologia do Instituto de Pesquisas Tecnológicas do Estado de São Paulo, para determinação de parâmetros físicos do solo.

Foram efetuados ensaios para determinação da granulometria, densidade do solo, densidade das partículas, porosidade total e condutividade hidráulica das amostras. 
Para determinação da granulometria, onde é considerada a distribuição das partículas sólidas do solo por divisão em classes de tamanho (IPT, 1995), foi utilizado - método de classificação do United States Department of Agricultural (USDA). 0 método do ensaio foi o do densímetro (Gee \& Bauder, 1986 em IPT, 1995), consistindo de tratamento das amostras por dispersantes químicos (hexametafosfato de sódio e hidróxido de sódio) e físicos (agitador de Wagner com 83 rotações por minuto durante período de 17 horas) e posterior peneiramento e sedimentação em água para quantificação dos diversos tamanhos das partículas sólidas.

A densidade das partículas foram determinadas pela quantificação da massa (pesagem) e do volume dos sólidos do solo. As partículas menores que $2,0 \mathrm{~mm}$ foram ensaiadas pelo método do picnômetro (Blake \& Hartge, $1986 \mathrm{em} \mathrm{IPT,} \mathrm{1995)} \mathrm{e} \mathrm{as}$ partículas globais pelo método do balão volumétrico.

Para determinação da densidade do solo (razão entre a massa das partículas sólidas e o volume total da amostra de solo) foi adotado o método do cilindro (Blake \& Hartge, 1986 em IPT, 1995), consistindo da coleta de amostra em um cilindro de $300 \mathrm{~cm}^{3}$, com amostrador Uhland modificado, e posterior determinação do peso da amostra após secagem a $105^{\circ} \mathrm{C}$. 


\subsubsection{Determinação da Condutividade Hidráulica}

A condutividade hidráulica foi determinada em laboratório, a partir das amostras de solo coletadas dos PMs 08 e 14, e em campo, através da realização de "slug tests".

O método adotado na execução dos testes laboratoriais foi o de carga hidráulica constante (Klute \& Dirksen, 1986 em IPT, 1995).

As amostras de solo com estruturas não deformadas foram saturadas em uma cuba de saturação, por um período de $48 \mathrm{~h}$, de forma a apresentar filme de água em toda a área da amostra (IPT, 1995)

Após completa saturação, as amostras foram submetidas à carga hidráulica constante de $7 \mathrm{~cm}$, por um período de $24 \mathrm{~h}$, sendo então medido o volume de água que passa por cada amostra após um tempo de 30 minutos.

$$
K=\frac{V \cdot L}{A t H}
$$

onde,

$\mathrm{K}=$ condutividade hidráulica $(\mathrm{L} / \mathrm{T})$

$V=$ volume de água que passa pela amostra $\left(L^{3}\right)$

$L=$ comprimento da amostra $(L)$

$A=$ superficie da amostra $\left(L^{2}\right)$

$t=$ tempo do ensaio $(T)$

$H=$ carga hidráulica aplicada $(L)$

Foram realizados testes para determinação da condutividade hidráulica in situ. Os slug tests (Hvorslev, 1951) foram realizados em 11 poços de monitoramento, PMs 07, 08, 12, 14, 16, 17, 18, 19, 22, 23 e 24.

Todos os testes foram efetuados de forma a medir o tempo de recuperação do nivel d'água após a retirada da sonda inserida no poço para provocar o deslocamento imediato do nível d'água estático. 
Foram utilizadas sondas com diâmetro de $7,62 \mathrm{~cm}$ ou 3" (três polegadas), sendo medido o nível d'água atingido logo após a inserção da sonda e atribuído a este valor o tempo igual a 0 (zero), ou tinicial. A partir de então, foram efetuadas medidas regulares dọs niveis d'água ao longo do tempo para atingir o nível d'água estático original.

A finalização das medidas se dá quando o rebaixamento atingir $10 \%$ da variação máxima $(H)$ atingida após inserção da sonda (Oliveira, 1992), correspondente à relação $\mathrm{H}-\mathrm{H}_{0}$ em tinicial (tempo inicial das medidas), sendo $\mathrm{H}_{0}$ o nivel d'água estático.

O valor de condutividade hidráulica determinada a partir do teste é decorrente da expressão elaborada por Hvorslev (1951):

$$
K=\frac{r^{2} \cdot \ln \left(\frac{L}{R}\right)}{2 \cdot L T_{o}}
$$

onde,

$\mathrm{K}=$ condutividade hidráulica $(\mathrm{L} / \mathrm{T})$

$r=$ raio do revestimento do poço $(L)$

$L=$ comprimento do filtro $(L)$

$R=$ raio do filtro $(L)$

$T_{0}=$ tempo no qual a variação do nível d'água é 0,37 da variação inicial $(T)$ 


\subsubsection{Determinação do Aporte de Água Subterrânea na Represa}

Segundo Salles et al, 1998, o teste do tambor (Seepage) constitui ferramenta importante na determinação do aporte freático vertical na zona que margeia a represa.

O método consiste no uso de medidores de infiltração para determinação de fluxo subterrâneo, relatado pela Lei de Darcy:

$$
Q=\frac{K \cdot d h / d l}{A}
$$

onde

$Q=$ fluxo da água subterrânea $\left(L^{3} / T\right)$

$A=$ área da seção transversal do tambor $\left(L^{2}\right)$

$\mathrm{dh} / \mathrm{dl}=$ gradiente hidráulico (adimensional)

$\mathrm{K}=$ condutividade hidráulica do material $(\mathrm{L} / \mathrm{T})$

As Figuras 04 a e 04 b apresentam esquemas de fluxos subterrâneos próximos de lagos, fundos de lagos e embasamento de cursos d'água, situações semelhantes às encontradas na área estudada.

Figura 04 a - Zonas de recarga e descarga (modificado de Lee, 1978)

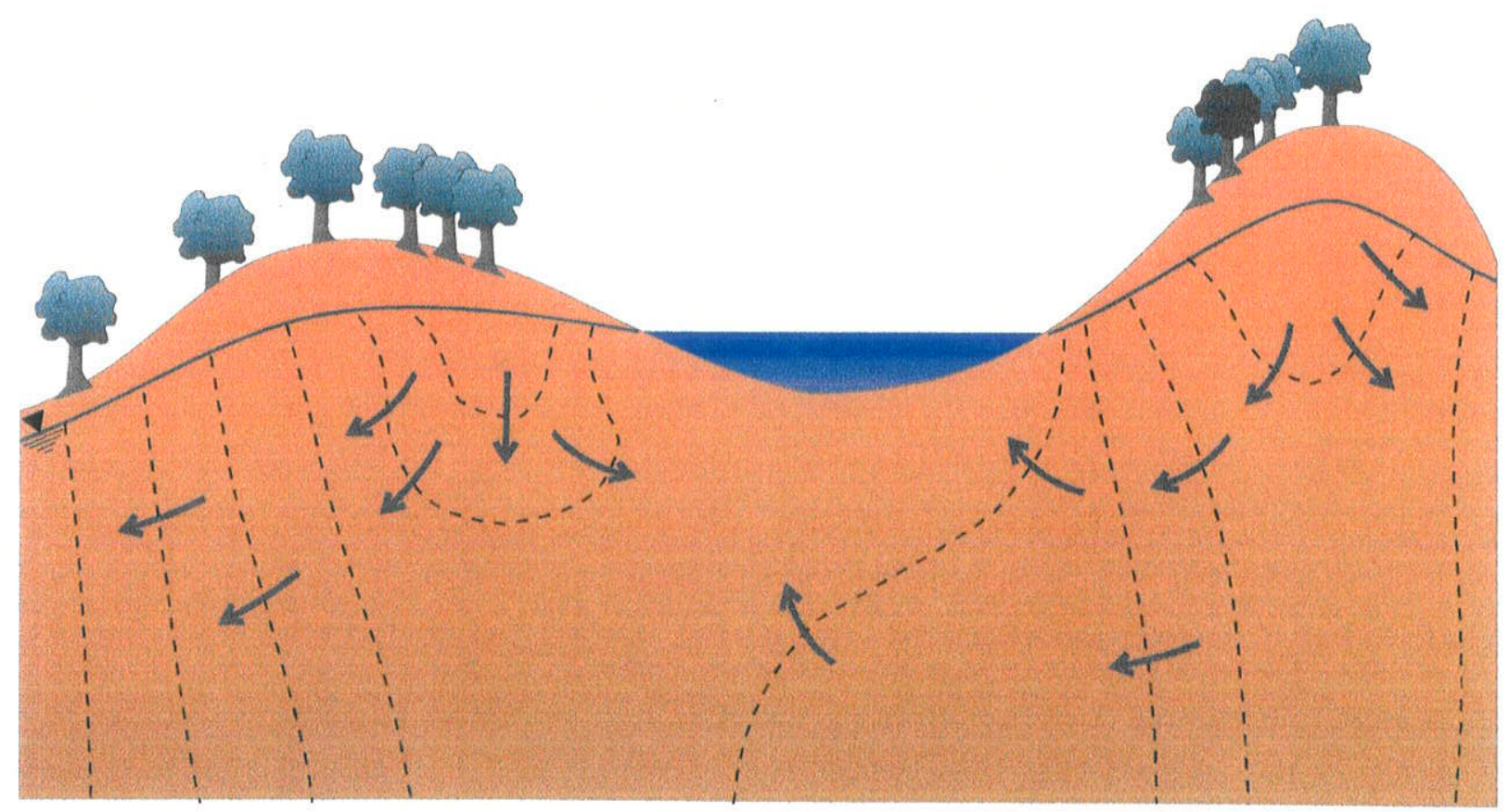

Avaliação de Área Contaminada por Compostos Orgânicos às Margens da Represa de Guarapiranga, no Município de São Paulo SP 
Figura 04 b - Modelo de descarga de água subterrânea em um lago ou estuário (modificado de Lee, 1978)

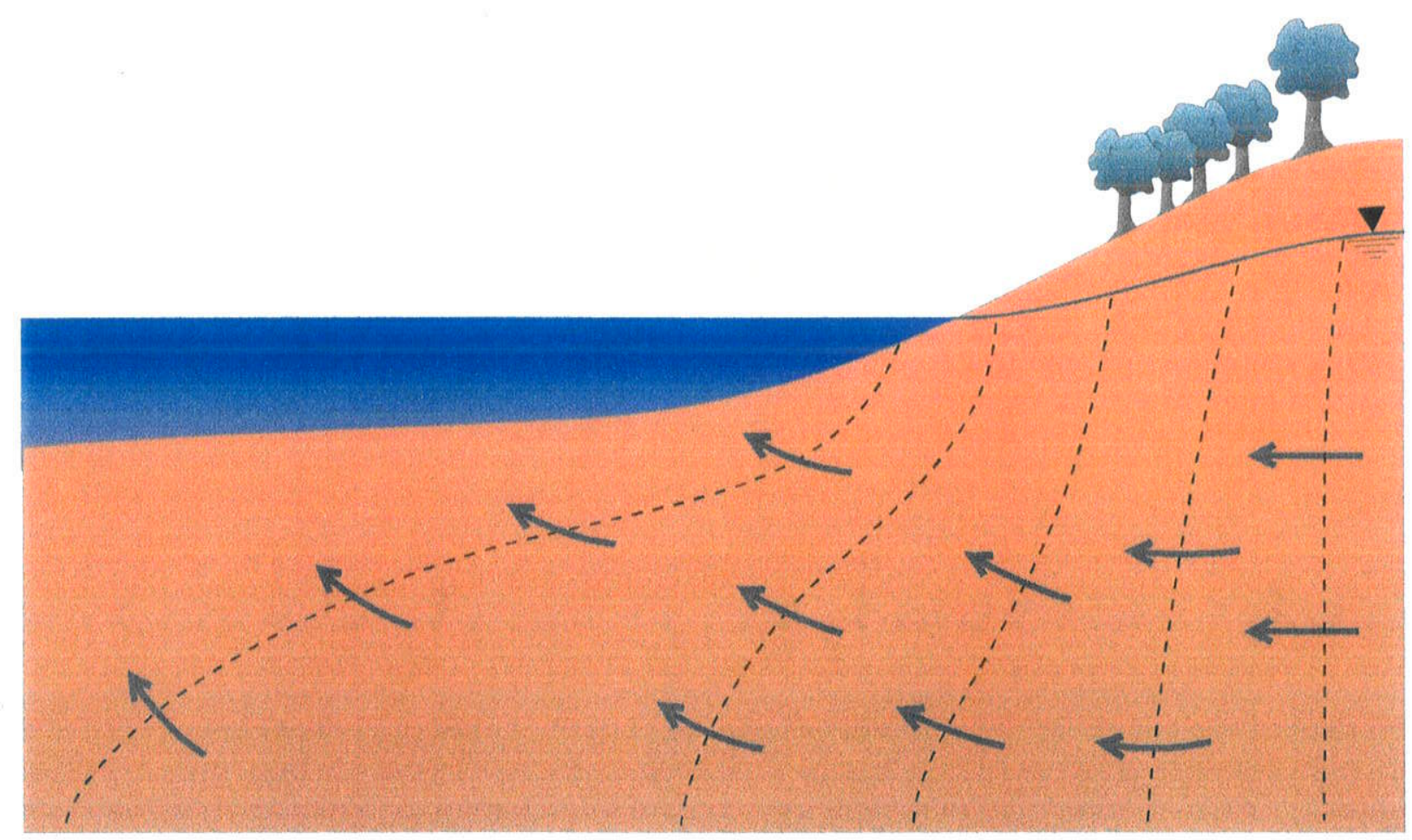

O sistema de fluxo é representado por linhas equipotenciais (linhas de igual carga hidráulica) e setas indicando o sentido de fluxo (perpendicular às linhas equipotenciais). Na base dos lagos e cursos d'água, o fluxo subterrâneo é ascendente, descendente ou horizontal, mas raramente inexistente.

A direção e taxa de fluxo são dependentes da fisiografia, textura e estratigrafia dos materiais subsuperficiais. Localmente, o fluxo nas bases pode variar drasticamente, proporcionando uma variedade de condições de observação em um único estudo de área. 
O emprego dos tambores (Foto 03) para determinação do fluxo ascendente de água na represa possui a vantagem de ser um método pouco dispendioso e com confiabilidade elevada sob a correta implantação do sistema no local de estudos.

No corrente trabalho, a metodologia descrita por Lee (1978) foi aplicada em duas

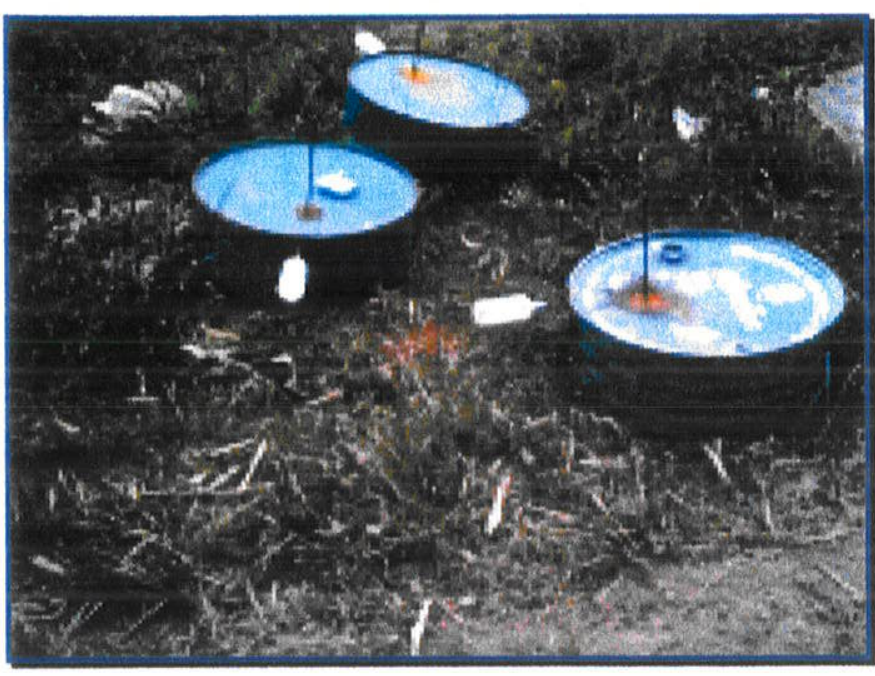

Foto 03 - Tambores utilizados no teste situações distintas, sob condições semelhantes às descritas no trabalho original do método e adaptada às condições de terreno alagadiço encontradas na zona que margeia a Represa de Guarapiranga.

Segundo Lee (1978), a utilização de seção transversal de um tambor metálico padrão (capacidade volumétrica total de aproximadamente $0,208 \mathrm{~m}^{3}$ ), permite a determinação de fluxos ascendentes de água subterrânea da ordem de $0,001 \mathrm{~cm}^{3} / \mathrm{m}^{2} \mathrm{~s}$.

Foi utilizada seção de tambor limpo com $20,0 \mathrm{~cm}$ de comprimento, $5,0 \mathrm{~cm}$ a mais do que o proposto na descrição do método, em virtude do fato de ter sido encontrada cobertura de lodo sob a lâmina d'água, com espessura média de $10,0 \mathrm{~cm}$, que dificulta a fixação do sistema. O diâmetro do tambor obedeceu ao indicado na descrição do método, possuindo $57,0 \mathrm{~cm}$, previamente esterilizado.

Para coleta de amostras de água foram utilizados recipientes plásticos esterilizados com capacidade volumétrica de $300 \mathrm{~mL}$, acoplado à tubos metálicos com diâmetros internos de $0,8 \mathrm{~cm}$ e soldados lateralmente ao tambor.

$\mathrm{Na}$ porção superior do sistema, foi instalado dreno vertical com $30,0 \mathrm{~cm}$ de comprimento, com o intuito de permitir a saída de ar durante a fixação do tambor, evitando desta forma alagamento e/ou obstrução do tubo coletor de amostras.

A configuração final do sistema é apresentada na Figura 05. 
Figura 05 Esquema Simplificado do Equipamento Utilizado para o Teste Seepage

(modificado de Lee, 1978)

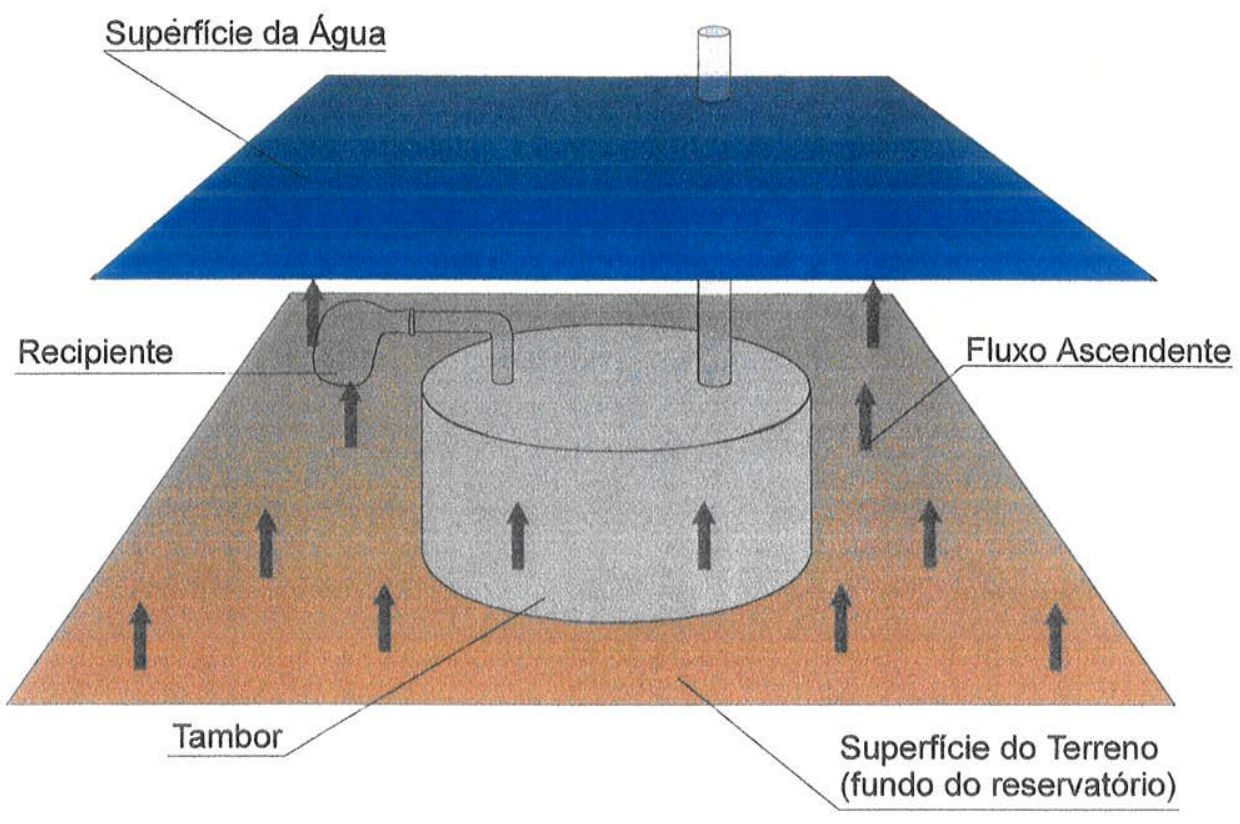

O tambor foi fixado no substrato (Foto 04), sob a lâmina d'água, observando sempre a manutenção de ligeira inclinação da superfície superior do tambor, para certificação da não penetração de quaisquer volumes de água no interior do tubo de coleta instalado lateralmente, mantendo aberta a saída de ar do dreno vertical.

Após a fixação do tambor, foi fechada a saída do dreno vertical de forma a evitar infiltração de águas superficiais e conseqüente contaminação do sistema e indesejado mascaramento

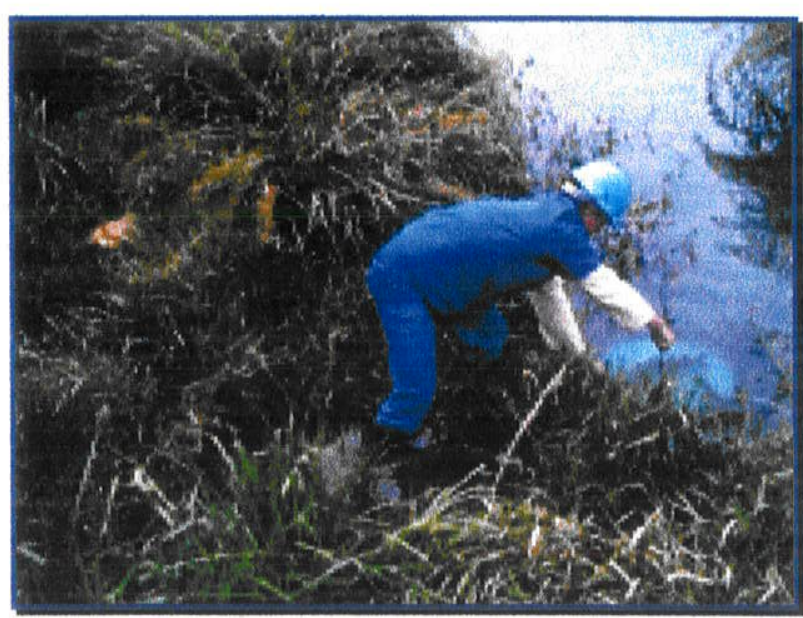

Figura 04 - Fixação do Tambor 03 dos dados. 
A partir das informações obtidas, determina-se o fluxo de água subterrânea, de acordo com a relação (Equação 05) derivada da lei de Darcy:

$$
Q=\frac{(\Delta v) \cdot 0,0643}{\Delta t}
$$

onde,

$Q=$ velocidade de fluxo $(\mu \mathrm{m} / \mathrm{s})$

$\Delta v=$ volume coletado no tubo $\left(\mathrm{cm}^{3}\right)$

$\Delta t=$ tempo de exposição do sistema (min)

$0,0643=$ fator de conversão de unidade

\subsubsection{Levantamento Planialtimétrico e Modelo Numérico de Terreno}

Todas as instalações da indústria, bem como a área de entorno foram locadas em planta para garantir a melhor visualização da área estudada e permitir o relacionamento do diversos dados obtidos através da adoção de sistema de coordenadas e cotas arbitrárias.

O levantamento planialtimétrico foi realizado com o auxílio de teodolito eletrônico, sendo as informações plotadas através do programa AutoCad, versão 14.

Os dados foram editados para apresentação em CorelDraw versão 8.0.

Os poços de monitoramento foram locados e referenciados a partir das suas cotas de boca, tomando por base a superfície do cap rosqueável.

A partir das cotas do terreno, foram confeccionadas manualmente as curvas topográficas. As curvas foram então superpostas ao mapa base e digitalizadas.

Através da utilização do software Surfer, versão 6.01, da Golden Software Inc, procedeu-se a interpolação das curvas digitalizadas, de formar a se obter uma superfície rasterizada do terreno e uma visão espacial da área estudada. 


\subsubsection{Potenciometria}

Os níveis d'água freáticos no interior dos PMs foram medidos em duas datas distintas, sendo 13 de novembro de 1997 e 16 de maio de 1998.

Para obtenção de resultados precisos, os poços de monitoramento foram esgotados e permaneceram em recuperação pelo período mínimo de $72 \mathrm{~h}$, sendo então efetuadas as medidas de campo.

As medidas foram efetuadas por medidor de NA eletrônico e trena e os dados foram tabelados para posterior interpretação.

As medidas dos níveis d'água no interior dos PMs foram relacionadas às cotas dos PMs obtidas do levantamento planialtimétrico, de forma a serem determinados os valores de potenciometria em cada poço nas duas datas de monitoramento.

A interpolação dos valores potenciométricos de cada poço permitiu a determinação da superficie potenciométrica nas duas datas monitoradas.

As superfícies potenciométricas foram correlacionadas à planta básica da indústria e arredores, de forma a permitir a definição dos sentidos preferenciais de fluxo da água subterrânea.

A partir dos mapas potenciométricos foram ainda determinados os valores dos gradientes hidráulicos na área, permitindo assim os cálculos para verificação da velocidade de fluxo da água subterrânea. 


\subsection{Modelo Conceitual de Transporte de Contaminantes}

\subsubsection{Coleta de Amostras de Água dos PMs}

As amostras de água foram coletadas de acordo com as metodologias apresentadas pela Environmental Protection Agency (USEPA, 1985) norte americana e por Souza (1997).

Três foram as datas de amostragens de água destinadas à análises laboratoriais, sendo 21 de outubro de 1997, 10 de dezembro de 1997 e 16 de maio de 1998.

\section{As amostragens (Foto 05)} foram realizadas com a utilização de Equipamentos de Proteção Individual (EPI), sendo máscara, botas, capacete, óculos e luvas cirúrgicas, estas últimas trocadas à cada novo processo de amostragem.

O amostrador, construído em PVC inerte, dotado de válvula de pé, permitiu a visualização da amostra coletada, evitando o armazenamento

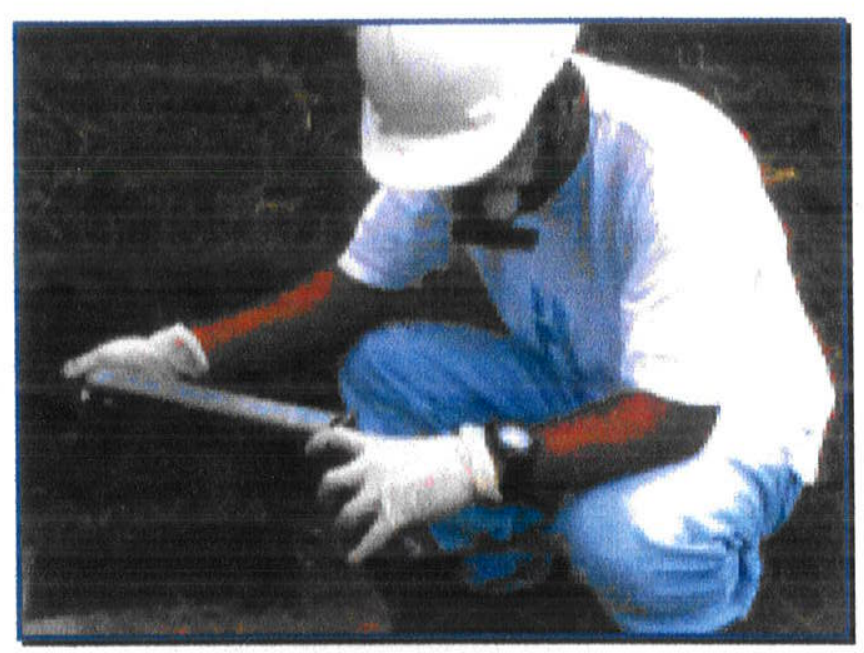

Foto 05 - Amostragem de PM de fase livre (produto puro) de contaminantes.

O desenho do amostrador, com diâmetro interno útil de $7,62 \mathrm{~cm}$ ou 3" (três polegadas) e $50 \mathrm{~cm}$ de comprimento, permitiu minimizar os efeitos de turbulência no interior do PM e possibilitou o lento armazenamento (velocidade inferior a $100 \mathrm{~mL}$ por minuto) da amostra no frasco utilizado, de forma a evitar a perda de compostos orgânicos voláteis.

Os frascos de vidro âmbar, com capacidade para $100 \mathrm{~mL}$ de amostra, foram esterilizados previamente em laboratório e vedadas por selo em teflon sob tampa plástica rosqueável. Foram coletadas quatro amostras (duas duplicatas) por poço, para determinação em separado de BTX e organoclorados. 
O armazenamento das amostras se fez de forma a preencher todo o espaço interno do frasco, evitando a formação de headspace. As amostras foram refrigeradas e mantidas em isopor, à temperatura aproximada de $4^{\circ} \mathrm{C}$, até o momento da análise.

\subsubsection{Coletà de Amostras de Água dos Tambores}

Dos tambores, foram coletadas amostras de água e encaminhadas imediatamente ao laboratório para determinação do volume de água, de forma a possibilitar os cálculos de vazão e determinação do aporte de água freático na represa.

A retirada do frasco coletor acoplado à lateral dos tambores, se deu através da utilização de alicate de pressão aplicado ao bico do frasco, de forma à evitar eventuais migrações para o interior ou exterior do recipiente.

O frasco coletado foi vedado por fita de teflon, armazenado em isopor refrigerado e encaminhado de imediato ao laboratório para realização de análises químicas.

\subsubsection{Análises Químicas de Amostras de Água}

As amostras de água foram enviadas à laboratório para determinação das concentrações dos compostos de interesse.

A determinação dos compostos Benzeno, Tolueno e Xilenos (BTX) foi feita em cromatógrafo a gás, modelo CG Master, equipado com detetor de ionização de chama (FID) e coluna capilar de metil silicone. O método de análises obedeceu à Norma 8020 da USEPA para determinação de compostos orgânicos voláteis aromáticos.

A determinação dos compostos organoclorados (Clorofórmio, 1,2 Dicloroetano, 1,1,1 Tricloroetano, Tetracloreto de Carbono, Tricloroetileno e Tetracloroetileno) foi feita por cromatógrafo a gás, modelo CG Master, equipado com detetor de captura de elétrons e coluna de vidro, 10\% Esqualano S/E CHR. WHP, $\phi 1,8$ "x $2 \mathrm{~m}$. O método de análises obedeceu à Norma Cetesb 4800 M791t, sendo utilizado padrão Merck.

Considerando que o limite de detecção do aparelho utilizado nas análises é de $5 \mu \mathrm{g} / \mathrm{L}$, os indícios de contaminação abaixo desta concentração foram considerados como nulos. 


\subsubsection{Interpretação das Plumas de Contaminação}

Os dados das análises químicas foram interpolados e correlacionados ao mapa base da área para interpretação das plumas de contaminação nas três datas de amostragem.

Para obtenção de maior detalhamento do cenário de contaminação, os contaminantes foram analisados separadamente, sendo confeccionadas plumas individuais para Benzeno, Tolueno, Xilenos, 1,2 Dicloroetano e 1,1,1 Tricloroetano. Desta forma, torna-se possivel a visualização das diversas fontes de contaminação identificadas na área e a interpretação evolutiva da contaminação como um todo através da análise de cada um dos contaminantes de interesse.

\subsubsection{Determinação de Parâmetros de Retardamento}

A parcela de contaminante que migra por meio da água subterrânea pode ser atenuada pelos fenômenos de adsorção do solo, retardando a velocidade de propagação da pluma de contaminação como um todo.

Para determinar a capacidade de retenção do solo, adotou-se o Batch Test, do qual foi obtido o valor do coeficiente de distribuição no solo $\left(K_{d}\right)$, a partir do qual foram calculados a fração de carbono orgânico $\left(f_{o c}\right)$ e o coeficiente de carbono orgânico $\left(K_{o c}\right)$ para o solo em questão e, tomando-se por base a relação apresentada na Equação 06 , segundo Fetter (1988):

$$
K_{d}=K_{o c} \cdot f_{o c}
$$

onde

$K_{d}=$ coeficiente de distribuição do solo $\left(M / L^{3}\right)$

$\mathrm{K}_{\mathrm{oC}}=$ coeficiente de carbono orgânico no solo para cada contaminante $\left(\mathrm{M} / \mathrm{L}^{3}\right)$

$f_{o c}=$ fração de carbono orgânico contido no solo (M/M) 
Para a realização do Batch Test, escolheu-se o Benzeno como traçador, pelo fato de sua solubilidade em água ser maior que a dos outros compostos considerados e pelo seu comportamento conhecido.

Foram definidos cinco pontos de concentração em água do traçador escolhido, no intervalo de $100 \mu \mathrm{g} / \mathrm{L}$ ao limite de solubilidade (1750 mg/L), à fim de que fossem preparadas cinco soluções correspondentes à cada concentração.

As soluções obtidas deste processo foram utilizadas para contaminar cinco amostras de solo (escolhidas entre dez amostras semelhantes) coletadas previamente durante as sondagens para instalação dos PMs.

Determinou-se a capacidade de campo do solo com a finalidade de definir a quantidade de solução a ser utilizada na contaminação das amostras. Após teste preliminar, foi definida a relação $2 \mathrm{H}_{2} \mathrm{O}: 1$ Solo como adequada ao teste por fornecer uma igualdade de volumes no frasco.

Realizou-se um branco com água destilada e concomitante preparação de amostras de referência para cada solo escolhido, à fim de indicar se houve ou não contaminação no solo coletado.

Efetuou-se, então, o complemento da solução com água destilada e posterior agitação dos frascos contendo as amostras contaminadas, os quais foram deixados em repouso em estufa $\left(a 30^{\circ} \mathrm{C}\right)$ para equilibrar.

Após realizar-se a extração, fez-se a análise química para determinação da concentração final na água dos frascos e comparou-se com a curva de calibração na mesma faixa de concentração.

\subsubsection{Coeficiente de Dis tribuição $\left(K_{d}\right)$}

Com os resultados da leitura, pôde-se determinar as concentrações iniciais e finais do contaminante tanto no solo quanto na amostra de água.

Desta forma, foi possível determinar o coeficiente de distribuição $\left(K_{d}\right)$ do solo para o Benzeno (traçador escolhido pelo comportamento conhecido e adequada solubilidade em água), de acordo com a Equação 07, que expressa a determinação de $\mathrm{K}_{d}$ em $1^{\mathrm{a}}$ ordem: 


$$
K_{d}=\frac{S}{C}
$$

onde

$K_{d}=$ coeficiente de distribuição $\left(L^{3} / M\right)$

$S=$ concentração final do contaminante no solo $(M / M)$

$\mathrm{C}=$ concentração final na água $\left(\mathrm{M} / \mathrm{L}^{3}\right)$

\subsubsection{Coeficiente de Ca rbono Orgânico no Solo e $\left(K_{o c}\right)$ e Fração Orgânica de Carbono $\left(f_{o c}\right)$ no solo}

A partir do Coeficiente de Distribuição $\left(K_{d}\right)$ do Benzeno, torna-se possível estimar a fração de carbono orgânico contido no solo $\left(f_{o c}\right)$, uma vez que o coeficiente de carbono orgânico no solo $\left(K_{o c}\right)$ pode ser determinado através do $K_{o w}$ (coeficiente de partição octanol/água), que já é conhecido para cada contaminante e proporcional ao $K_{o c}$ através da Equação 08 (Schwarzenbach and Westfall, 1981).

$$
\log \left(K_{o c}\right)=0,72 \log \left(K_{\text {ow }}\right)+0,49
$$

Assume-se a partir de então que o solo local possui homogeneidade quanto à fração de carbono orgânica $\left(f_{o c}\right)$ encontrada. Por sua vez, os valores de $K_{o c}$ são tabelados para uma série de substâncias conhecidas e desta forma tornou-se possivel a obtenção de $K_{d}$ para cada um dos contaminantes estudados, por substituição na Equação 06.

\subsubsection{Determinação do Fator de Retardamento}

A velocidade de contaminantes transportados por advecção em água subterrânea pode ser inferior à velocidade da própria água subterrânea. Ao tratarmos de transporte de contaminante através da água subterrânea, devemos considerar o fator de retardamento (Fetter, 1988), determinado através da Equação 09. 


$$
F_{r}=1+\left(\frac{\rho_{b}}{\theta}\right) \cdot K_{d}
$$

onde

$F_{r}=$ fator de retardamento (adimensional)

$\rho_{b}=$ densidade de uma amostra de solo seco $\left(M / L^{3}\right)$

$\theta=$ porosidade do solo (adimensional)

O fator de retardamento contribui para atraso no deslocamento das substâncias transportadas pela água subterrânea, proporcionalmente à capacidade de adsorção do solo.

\subsubsection{Determinação da Velocidade de Deslocamento da Pluma de Contaminação}

Considerando-se o fator de retardamento, sabe-se que há uma defasagem da velocidade final de propagação da frente de soluto em relação à velocidade linear média da mesma frente, seguindo a Equação 10 (Fetter,1988).

$$
V_{c}=\frac{V_{x}}{F_{r}}
$$

onde

$V_{c}=$ velocidade da frente de soluto $(L / T)$

$v_{x}=a$ velocidade linear média da água subterrânea $(L / T)$

Desta forma, com a determinação da velocidade real final de propagação da frente da pluma, torna-se possivel determinar o tempo necessário para chegada da contaminação delimitada na indústria à zona que margeia a represa, manancial a ser protegido. 


\section{Resultados Obtidos}

\subsection{Modelo Conceitual de Fluxo da Água Subterrânea}

\subsubsection{Caracterização Geológica}

A área de estudos está situada sobre rochas pré-cambrianas do embasamento cristalino, constituídas por suítes graníticas sintectônicas do Proterozóico Superior (IPT, 1981).

A litologia está inserida no Grupo Açungui, Complexo Pilar, o qual é caracterizado pela predominância de quartzo mica xistos, biotita quartzo xistos, muscovita quartzo xistos, granada biotita xistos, xistos grafitosos, clorita xistos, sericita biotita xistos, talco xistos, magnetita xistos e calcoxistos com intercalações subordinadas de filitos, quartzitos, calcossilicáticas e metassiltitos.

Estruturas metamórficas são ainda preservadas no solo de alteração, tendo sido identificadas foliações com direção predominante NE-SW e mergulho preferencial médio de $70^{\circ}$ rumo a NW.

As perfurações a trado mecanizado interceptaram perfis (Apêndice 01) de solo de alteração com profundidades variando entre 1,50 m (PM-30) e 17,00 m (PM-05) até litologia impenetrável ao equipamento de perfuração.

Superficialmente foi ultrapassada camada de aterro com características granulométricas e composicionais semelhantes ao solo subjacente e identificada em todas as sondagens (Apêndice 01) com espessuras variando entre 0,90 m (PM-08) e $4,00 \mathrm{~m}$ (PM-23), atribuída ao processo de terraplanagem durante a instalação da indústria.

\subsubsection{Poços de Monitoramento}

No total, foram instalados 33 Poços de Monitoramento (PMs) na área da indústria, de acordo com a distribuição apresentado na Figura 06. 
Figura 06 - Mapa de Localização dos PMs.

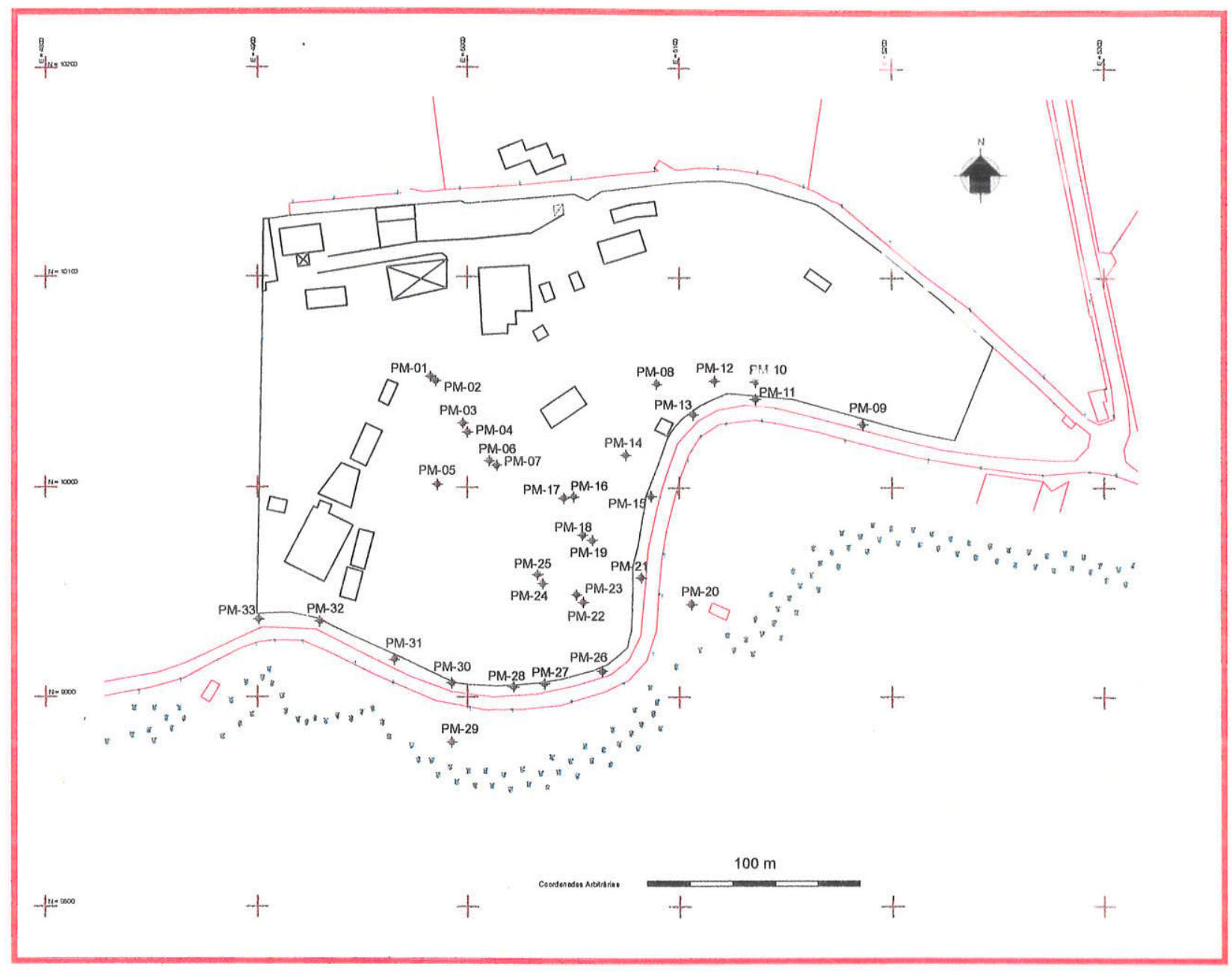

Para os valores de $m$ e $n$ (Equação 01) foram considerado igualmente o valor 4 , o qual define uma faixa de granulometria do material filtrante a partir de duas curvas semelhantes, contudo, defasadas 4 vezes com relação à $D 15$ e $D 85$ do solo, fornecendo ao pré-filtro características de altíssima condutividade hidráulica e baixo carreamento de partículas

O gráfico 01 apresenta a as curvas de intervalo do pré-filtro a partir da curva aproximada de granulometria do solo estudado. 
Gráfico 01 - Determinação da Granulometria do Pré-Filtro

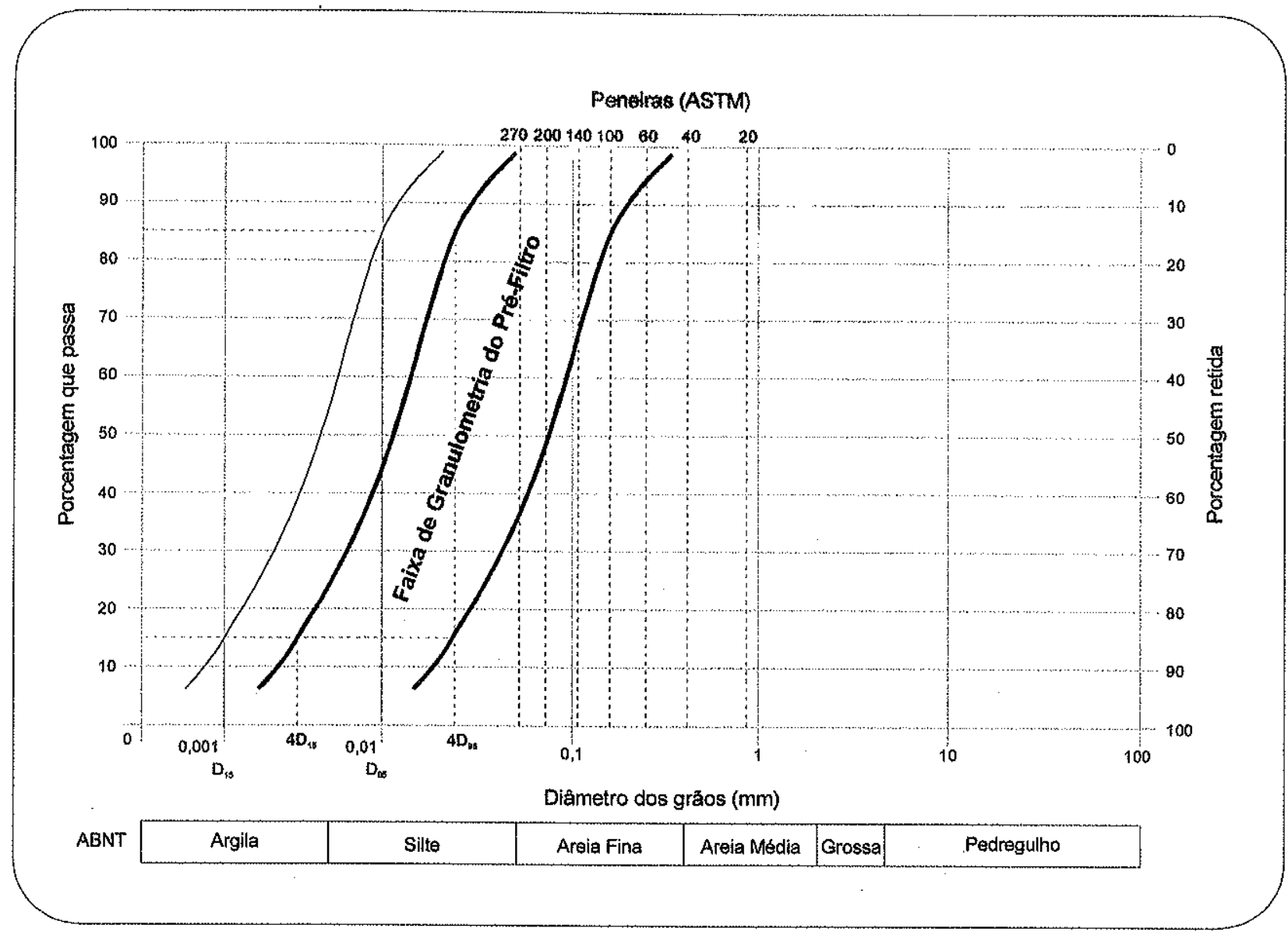

O Gráfico 01 indica que o pré-filtro utilizado nos PMs possui granulometria contida no intervalo de silte à areia fina, de acordo com a classificação ABNT apresentada no próprio gráfico.

Todos os poços foram instalados através da utilização de trado mecanizado e suas profundidades foram limitadas pela presença, em subsuperfície, de litologia impenetrável ao equipamento de perfuração.

O Apêndice 01 apresenta os perfis descritivos das sondagens realizadas para instalação dos PMs, bem como a representação esquemática da metodologia de revestimento e acabamento dos poços.

A manutenção das condições físicas dos PMs consumiu grande parte das horas de trabalho destinadas à amostragem e ao monitoramento técnico. 
Poços situados na parte externa da empresa, ao longo do muro, foram alvos de depredações por vezes irrecuperáveis.

Mesmo no interior na indústria, alguns poços foram danificados e soterrados pela disposição de montes de entulho, podendo eventualmente ter sido contaminados e, portanto, sendo descartados.

Ao longo do período de trabalhos no local, os poços sofreram manutenção, tendo sido retirados fragmentos de diversas naturezas (pedras principalmente) e realizado o desenvolvimento dos poços com injeção de água sob pressão controlada.

Ainda assim, ao término do período de trabalhos, 10 dos 33 poços inicialmente instalados apresentam-se inutilizados para amostragem, estando com acabamento superficial destruído, desprovidos de cap, obstruídos internamente por objetos diversos ou ainda soterrados por entulho.

Os poços danificados, foram os PMs 06, 10, 12 14, 24 e 25, no interior da indústria, e os PMs $20,21,26$ e 29 , no exterior da indústria.

\subsubsection{Determinação de Parâmetros Físicos do Solo}

Amostras deformadas e não deformadas de solo foram coletadas e analisadas no Laboratório de Física do Solo do Instituto de Pesquisas Tecnológicas do Estado de São Paulo - IPT. Os resultados das análises são apresentados na Tabela 01.

Tabela 01 - Resultados dos Ensaios de Solo Realizados no IPT

\begin{tabular}{|c|c|c|c|c|c|c|c|c|c|c|c|}
\hline \multirow[t]{2}{*}{ Amostra } & \multirow[t]{2}{*}{$\begin{array}{l}\text { Prof } \\
(\mathrm{cm})\end{array}$} & \multicolumn{4}{|c|}{ Granulometria } & \multicolumn{2}{|c|}{$\begin{array}{l}\text { Densidade do } \\
\text { Solo }\end{array}$} & \multicolumn{2}{|c|}{$\begin{array}{l}\text { Densidade de } \\
\text { Partícula }\end{array}$} & \multirow{2}{*}{$\begin{array}{c}\text { Poros } \\
\text { Total } \\
(\%)\end{array}$} & \multirow{2}{*}{$\begin{array}{l}\text { Condut } \\
\text { Hidráulica } \\
(\mathrm{cm} / \mathrm{s})\end{array}$} \\
\hline & & areia & silte & $\begin{array}{c}\text { argila } \\
\text { total }\end{array}$ & $\begin{array}{l}\text { argila } \\
\text { disper }\end{array}$ & $\begin{array}{l}\mathrm{seco} \\
\left(\mathrm{g} / \mathrm{cm}^{3}\right)\end{array}$ & $\begin{array}{l}\text { Satur. } \\
\left(\mathrm{g} / \mathrm{cm}^{3}\right)\end{array}$ & $\begin{array}{l}<2 \mathrm{~mm}^{3} \\
\left(\mathrm{~g} / \mathrm{cm}^{3}\right)\end{array}$ & $\underset{\left(\mathrm{g} / \mathrm{cm}^{3}\right)}{\text { global }}$ & & \\
\hline PM-08 & $50-57$ & 40 & 48 & 12 & 03 & 1,37 & 1,86 & 2,64 & 2,80 & 52 & $4,5 \times 10^{-6}$ \\
\hline PM-08 & $100-107$ & 43 & 50 & 07 & 04 & 1,47 & 1,94 & 2,74 & 2,70 & 51 & $7,2 \times 10^{-6}$ \\
\hline PM-14 & $40-47$ & 53 & 35 & 12 & 12 & 1,35 & 1,83 & 2,77 & 2,59 & 53 & $9,5 \times 10^{-6}$ \\
\hline PM-14 & $70-77$ & 60 & 29 & 11 & 11 & 1,37 & 1,82 & 2,69 & 2,80 & 50 & $1,4 \times 10^{-5}$ \\
\hline
\end{tabular}


Os valores de porosidade total e condutividade hidráulica apresentados na Tabela 01 podem ser associados, segundo Fetter (1988), a solos com granulometria variando entre argila e areia fina, com maior distribuição no intervalo de abrangência de silte, silte arenoso e areia argilosa.

Esta associação vai ao encontro das descrições litológicas (Apêndice 01) obtidas a partir das sondagens efetuadas na área de estudos.

\subsubsection{Determinação da Condutividade Hidráulica}

Foram realizados 11 Slug Tests para determinação, em campo, da condutividade hidráulica $(\mathrm{K})$ do aquífero estudado.

A Tabela 02 apresenta os valores de condutividade hidráulica calculados para cada um dos poços ensaiados.

Tabela 02 - Resultados dos Valores de Condutividade Hidráulica Obtidos dos S/ug Tests

\begin{tabular}{|c|c|}
\hline PM Ensaiado & Condutividade Hidráulica $(\mathrm{cm} / \mathrm{s})$ \\
\hline PM-07 & $7,92 \times 10^{-5}$ \\
\hline PM-08 & $1,17 \times 10^{-4}$ \\
\hline PM-12 & $4,57 \times 10^{-6}$ \\
\hline PM-14 & $1,23 \times 10^{-4}$ \\
\hline PM-16 & $1,74 \times 10^{-5}$ \\
\hline PM-17 & $3,50 \times 10^{-5}$ \\
\hline PM-18 & $5,02 \times 10^{-5}$ \\
\hline PM-19 & $5,07 \times 10^{-5}$ \\
\hline PM-22 & $4,43 \times 10^{-5}$ \\
\hline PM-23 & $2,78 \times 10^{-5}$ \\
\hline PM-24 & $1,01 \times 10^{-4}$ \\
\hline
\end{tabular}

A Figura 07 apresenta o conjunto de gráficos derivados dos dados de campo obtidos durante os slug tests. 
Figura 07 - Gráficos de Slug Tests
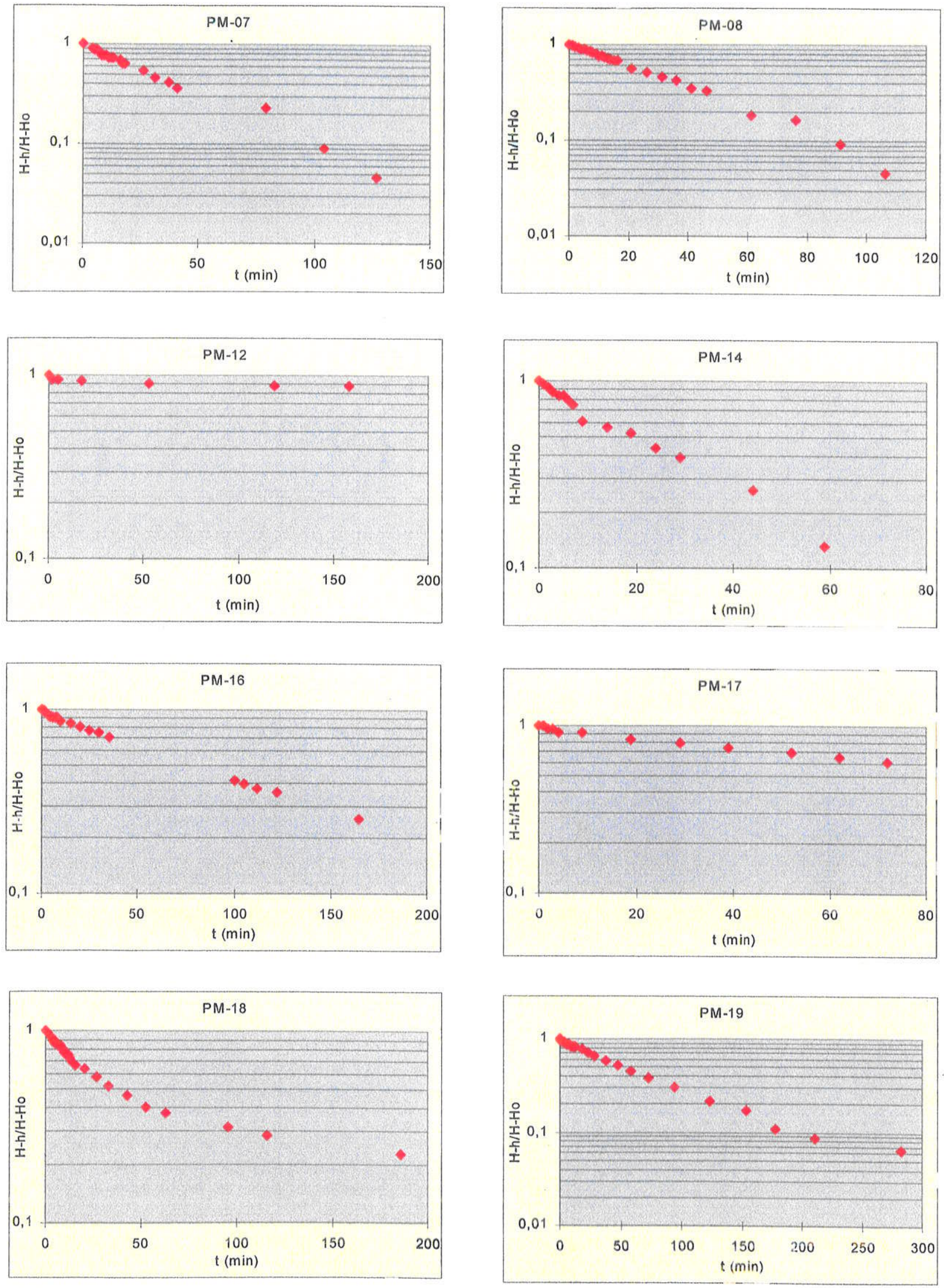

Avaliação de Área Contaminada por Compostos Orgânicos às Margens da Represa de Guarapiranga, no Município de São Paulo - SP 
Figura 07 (continuação) - Gráficos de Slug Tests
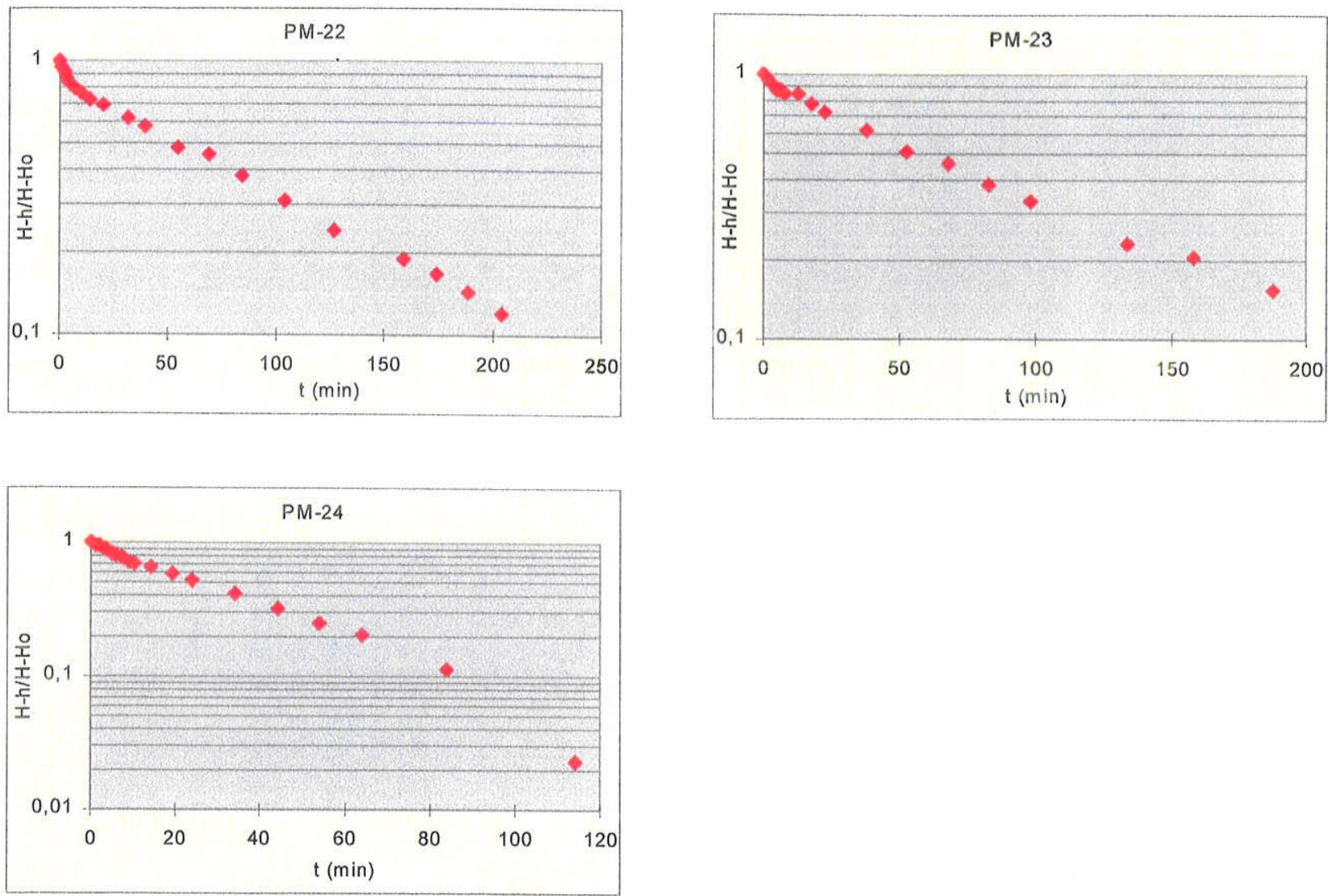

De uma maneira geral, os testes laboratoriais determinaram valores de condutividade hidráulica inferiores aos testes de campo.

A comparação direta entre os valores determinados para os PMs 08 e 14, cujas amostras de sondagens foram enviadas ao laboratório e também foram ensaiados em campo, indica variações chegando atingir duas casas decimais.

O PM-14 apresentou, tanto em laboratório quanto em campo, os maiores valores de condutividade hidráulica, sendo $1,40 \times 10^{-5} \mathrm{~cm} / \mathrm{s}$ no primeiro caso e $1,23 \times 10^{-4} \mathrm{~cm} / \mathrm{s}$ no segundo caso.

O menor valor encontrado para a condutividade hidráulica foi idêntico (até a primeira casa decimal) tanto em campo quanto em laboratório, apresentando o PM-12 o valor de $4,57 \times 10^{-6} \mathrm{~cm} / \mathrm{s}$ em campo e o PM-08 o valor de $4,50 \times 10^{-6} \mathrm{~cm} / \mathrm{s}$ em laboratório. 
Para efeito de condutividade hidráulica, o intervalo de variação entre duas casas decimais representa coerência dos dados, sendo semelhantes os intervalos litológicos atribuídos tanto por Fetter (1988) quanto por Freeze (1979), que apresenta para o os valores de $\mathrm{K}$ entre $10^{-4} \mathrm{~cm} / \mathrm{s}$ e $10^{-6} \mathrm{~cm} / \mathrm{s}$, litologias decritas como silte, silte arenoso, arenito, calcário ou ainda rochas ígneas e metamórficas fraturadas. A literatura confirma a geologia determinada em campo.

\subsubsection{Determinação do Aporte de Água Subterrânea na Represa}

Para determinação do aporte freático na zona que margeia a represa, sete tambores foram instalados em duas datas distintas, permitindo verificar eventuais variações no regime de fluxo local ao longo do ciclo hidrológico. A distribuição dos tambores é apresentada na Figura 08.

Figura 08 - Mapa de Localização dos Tambores

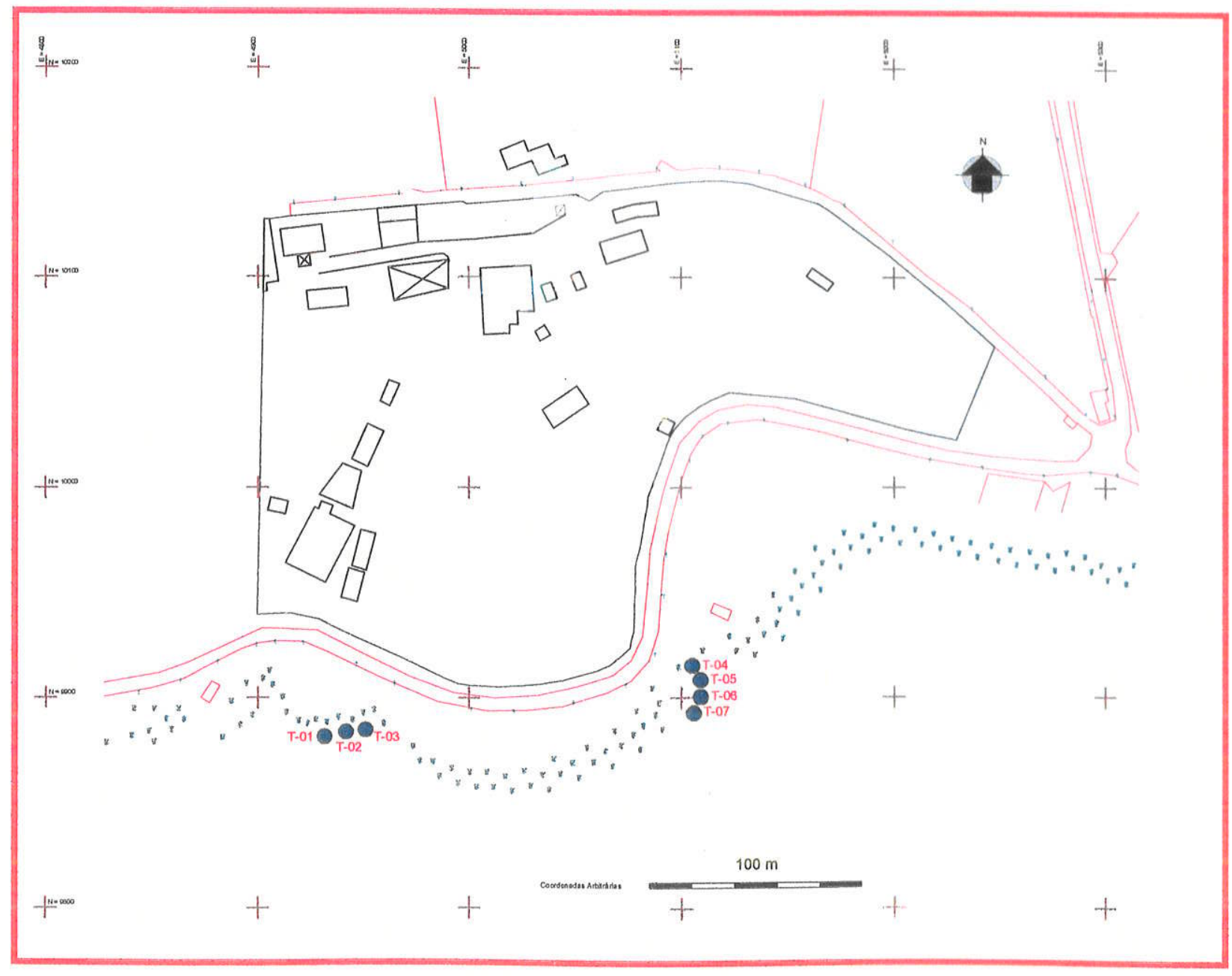


Duas áreas com características distintas foram selecionadas para instalação dos tambores (Salles et al. 1998)

A primeira área, situada na porção sul da indústria, onde foram instalados os Tambores 01 a 03, é caracterizada pela presença de vegetação aquática, com lâmina d'água média de 0,30 $\mathrm{m}$ nas margens da represa e ainda com presença de substrato orgânico com espessura média de $0,10 \mathrm{~m}$ no local.

A segunda área selecionada, situada a SE da indústria, onde foram instalados os Tambores 04 a 07 , é caracterizada por vegetação arbustiva típica de zonas alagadiças com raízes pouco penetrativas, sendo o solo constituído por material argiloso com grande porcentagem de matéria orgânica.

A definição das áreas citadas, de acordo com as suas características, implicou na adoção de duas metodologias diferentes de instalação do sistema.

$\mathrm{Na}$ primeira área, a presença de lâmina d'água espessa, semelhante à descrita por Lee (1978), permitiu a instalação direta do sistema, ficando a superfície superior do tambor sob uma coluna d'água de aproximadamente $0,25 \mathrm{~m}$, ou seja, mantendo-se o dreno vertical superior exposto $0,05 \mathrm{~m}$ para fora d'água (Foto 06).

O processo de instalação dos tambores 04 a 07, na segunda área, necessitou de preparação prévia do local, uma vez que não foi encontrada lâmina d'água aflorante e suficiente para encobrir o tambor de forma a permitir a coleta de amostras de água.

Foram escavadas 04 regiões com dimensões suficientes à instalação

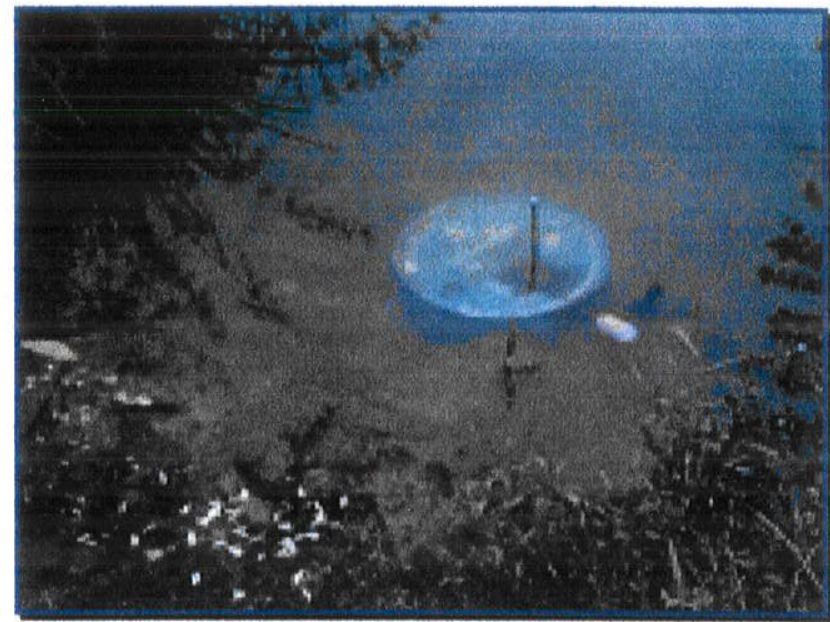

Foto 06 - Tambor 02

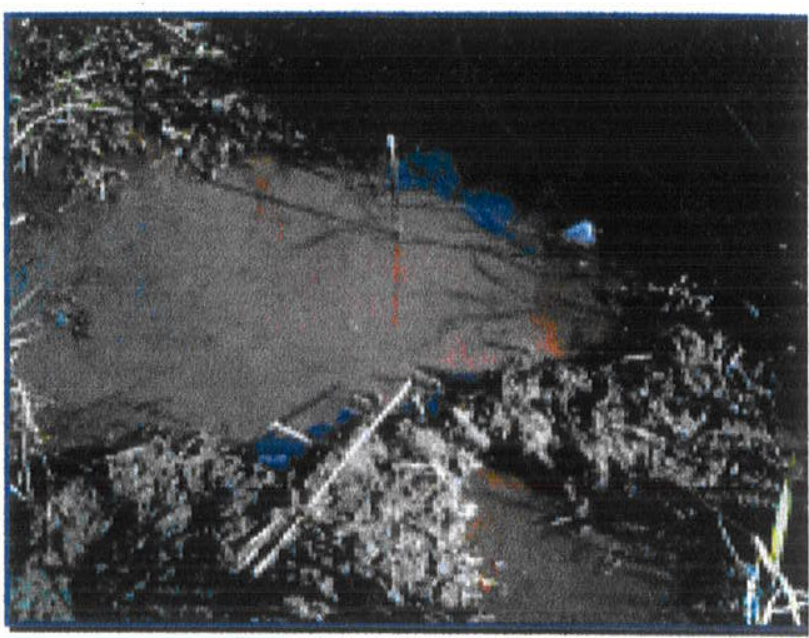

Foto 07 -Tambor T-05 
dos tambores (Foto 07), tendo sido preservado um período mínimo de 24 horas para estabilização do nível d'água nos locais escavados. A estabilização do nível d'água após $24 \mathrm{~h}$, sem precipitação pluviométrica registrada, deu-se no nível do solo, caracterizaņdo a posição sub aflorante da água. Os tambores foram instalados sob coluna d'água de aproximadamente $0,10 \mathrm{~m}$.

Após período de repouso dos tambores, foram retirados os tubos coletores para determinação do volume de água armazenado e cálculo de vazão a partir do tempo de ensaio.

Os volumes de amostras armazenadas nos tubos coletores, nas duas baterias de tambores instaladas na área, são apresentadas na Tabela 03.

Tabela 03 - Volumes Amostrados nos Testes do Tambor (Seepage)

\begin{tabular}{|c|c|c|c|c|}
\hline \multirow{2}{*}{ Tambor } & \multicolumn{2}{|c|}{$\begin{array}{c}\text { Primeira Bateria } \\
\text { (novembro/ 1997) }\end{array}$} & \multicolumn{2}{|c|}{$\begin{array}{c}\text { Segunda Bateria } \\
\text { (maio/ 1998) }\end{array}$} \\
\cline { 2 - 5 } & $\begin{array}{c}\text { Tempo de } \\
\text { Exposição } \\
(\mathrm{h})\end{array}$ & $\begin{array}{c}\text { Volume de } \\
\text { Agua Obtido } \\
(\mathrm{mL})\end{array}$ & $\begin{array}{c}\text { Tempo de } \\
\text { Exposição } \\
\text { (h) }\end{array}$ & $\begin{array}{c}\text { Volume de } \\
\text { Agua Obtido } \\
\text { (mL) }\end{array}$ \\
\hline T1 & 96,00 & 22,00 & 71,37 & 9,70 \\
\hline T2 & 96,00 & 24,40 & 69,08 & 5,10 \\
\hline T3 & 96,00 & 0,00 & 68,92 & 2,30 \\
\hline T4 & 72,00 & 5,00 & 74,67 & 33,10 \\
\hline T5 & 72,00 & 3,50 & 68,07 & 18,50 \\
\hline T6 & 72,00 & 13,30 & - & - \\
\hline T7 & 72,00 & 27,70 & - & \\
\hline
\end{tabular}

$\mathrm{Na}$ primeira bateria de testes, a inexistência de água no recipiente de coleta acoplado ao tambor 3 , deve-se ao fato deste ter sido instalado sobre substrato orgânico muito espesso, impedindo a correta fixação do tambor e propiciando a entrada de ar no sistema, o que inibiu a migração de água para o interior do tubo coletor. 
$\mathrm{Na}$ segunda bateria de testes, os tambores 06 e 07 foram danificados por terceiros, estando deslocados do local original de instalação, o que invalidou a amostragem.

A Tabela 04 apresenta os resultados obtidos dos cálculos para determinação das velocidades de fluxos utilizando-se os dados dos testes.

Tabela 04 - Fluxo Calculado Para os Tambores Amostrados

\begin{tabular}{|c|c|c|}
\hline \multirow{2}{*}{ Tambor } & $\begin{array}{c}\text { Primeira Bateria } \\
\text { (novembro/ 1997) }\end{array}$ & $\begin{array}{c}\text { Segunda Bateria } \\
\text { (maio/ 1998) }\end{array}$ \\
\cline { 2 - 3 } & $\mathrm{Q}(\mu \mathrm{m} / \mathrm{s})$ & $\mathrm{Q}(\mu \mathrm{m} / \mathrm{s})$ \\
\hline T1 & $2,45 \times 10^{-4}$ & $1,45 \times 10^{-4}$ \\
\hline T2 & $2,72 \times 10^{-4}$ & $7,90 \times 10^{-5}$ \\
\hline T3 & N.A. & $3,60 \times 10^{-5}$ \\
\hline T4 & $7,44 \times 10^{-5}$ & $4,75 \times 10^{-4}$ \\
\hline T5 & $5,20 \times 10^{-5}$ & $2,88 \times 10^{-4}$ \\
\hline T6 & $1,98 \times 10^{-4}$ & NA \\
\hline T7 & $4,12 \times 10^{-4}$ & NA \\
\hline
\end{tabular}

NA - não aplicável

Os valores apresentados na Tabela 04, correspondem ao aporte vertical de água subterrânea em volumes localizados da zona que margeia a represa, considerando as seções transversais dos tambores e as profundidades nas quais foram realizados os testes.

Para o solo encontrado no local, de acordo com a classificação apresentada por Fetter (1988), pode ser considerado um valor médio de $10 \%$ para a porosidade efetiva para fluxo $\left(n_{\mathrm{ef}}\right)$. Desta forma, as máximas velocidades da água subterrânea, na sua chegada à zona que margeia a represa, nas duas datas em que foram instalados os tambores, são iguais a $4,12 \times 10^{-9} \mathrm{~m} / \mathrm{s}$ (primeira bateria) e $4,75 \times 10^{-9} \mathrm{~m} / \mathrm{s}$ (segunda bateria). Por sua vez, os valores mínimos da velocidade da água subterrânea, nas duas datas consideradas, e para a porosidade efetiva para fluxo de $10 \%$, são iguais a $5,2 \times 10^{-10} \mathrm{~m} / \mathrm{s}$ (primeira bateria) e $3,6 \times 10^{-10} \mathrm{~m} / \mathrm{s}$. As velocidades extremas de fluxo da água subterrânea na chegada à represa, calculadas a partir do teste dos tambores (Seepage), encontram-se em um intervalo de uma ordem de grandeza, demonstrando coerência dos testes e eficiência nos trabalhos de amostragem e análises. 


\subsubsection{Levantamento Planialtimétrico e Modelo Numérico de Terreno}

A partir do levantamento planialtimétrico realizado na área de estudos, foram obtidas cotas arbitrárias de todas as instalações presentes no local, permitindo a confecção do mapa topográfico apresentado na Figura 09 por interpolação das curvas altimétricas.

Figura 09 - Mapa Topográfico

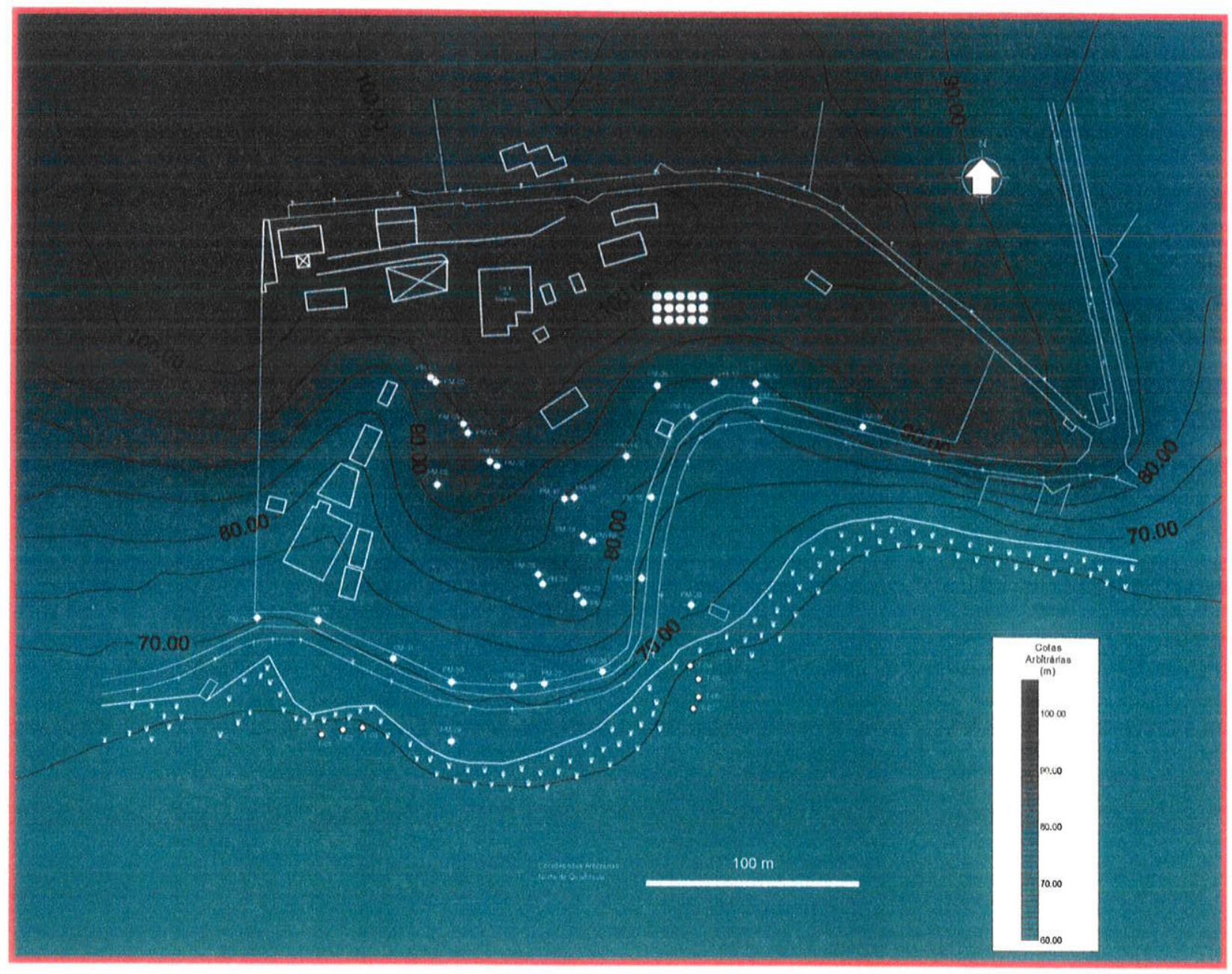

A partir do mapa topográfico, foi construído o Modelo Numérico do Terreno (MNT), possibilitando uma visão espacial da superfície da área de estudos. 
As Figuras 10 a e $10 \mathrm{~b}$ apresentam MNTs com vistas a partir de SE-NW e SWNE. A visão SE-NW está sujeita à rotação horizontal de $318^{\circ}$ e inclinação vertical (tilt) de $18^{\circ}$, enquanto a visão SW-NE está rotacionada horizontalmente $42^{\circ}$ e com inclinação vertical de $24^{\circ}$, ambas com vista em perspectiva.

Figura 10 a - MNT vista SE-NW

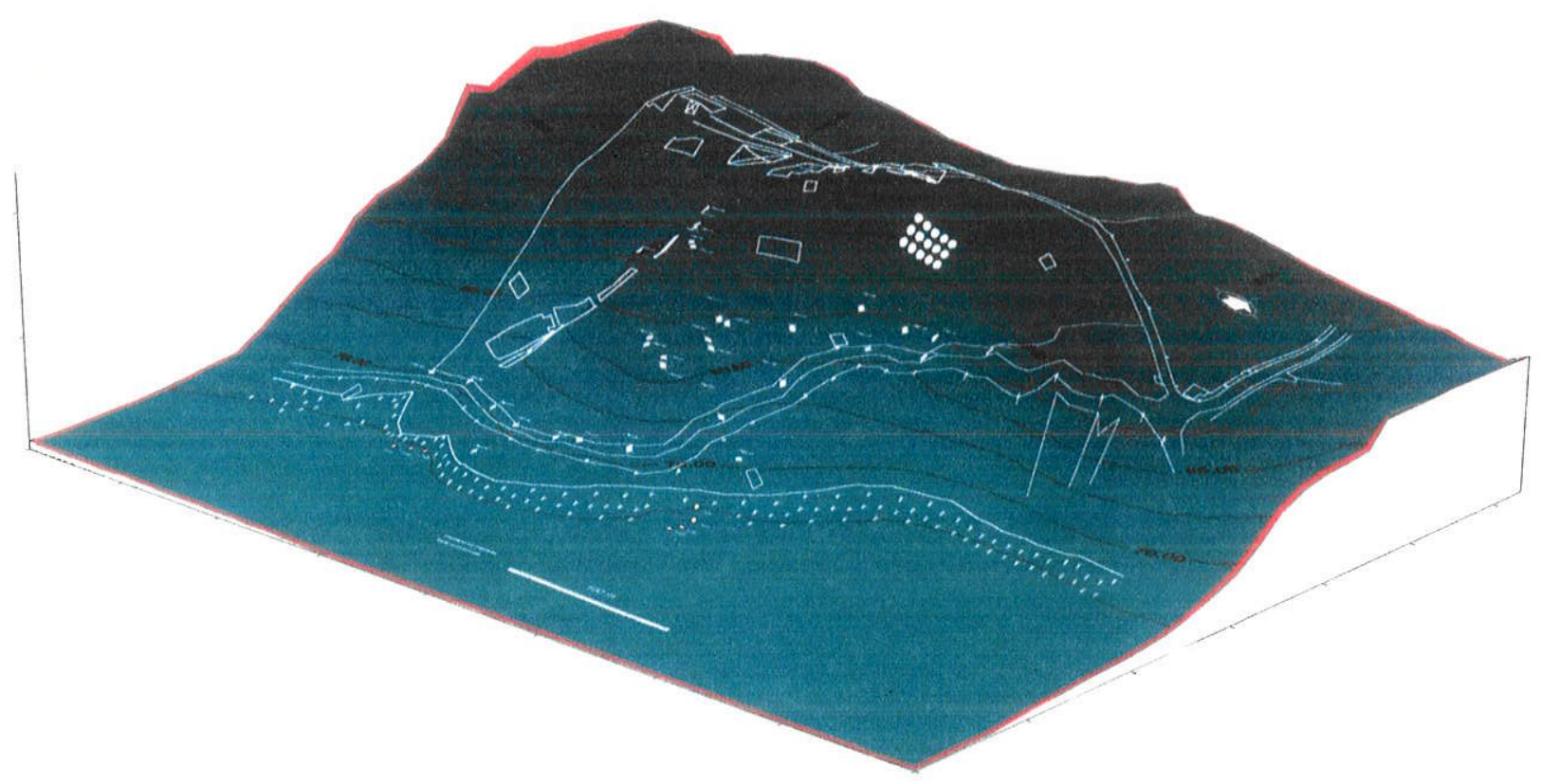

Figura $10 \mathrm{~b}$ - MNT vista SW-NE

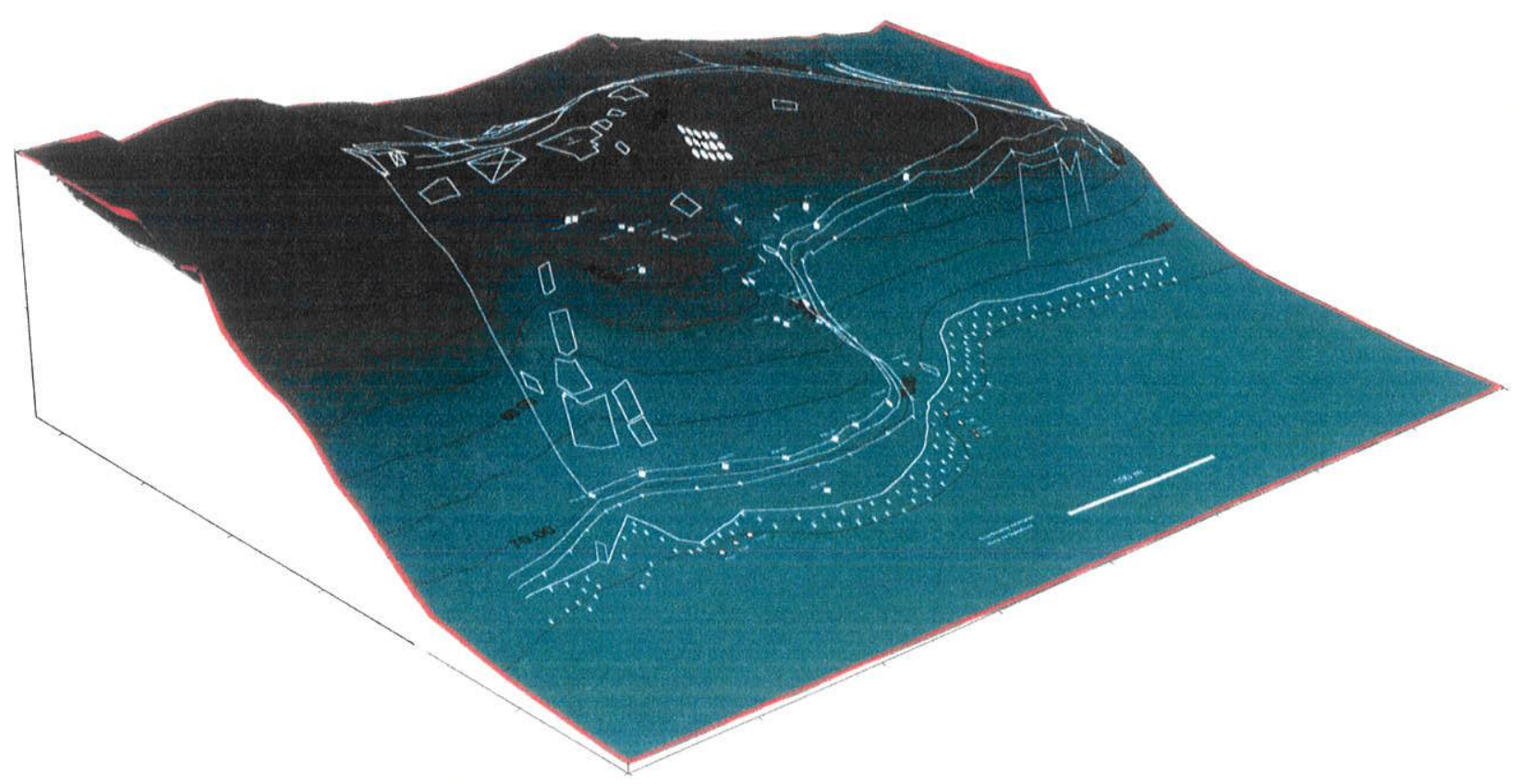


Os dois modelos MNTs evidenciam a presença de patamar na porção noroeste da área, com altitude em torno de $100 \mathrm{~m}$ (cota arbitrária). A porção central da área apresenta declividade média de $33,75 \%$, com caimento orientado fundamentalmente para sul. A porção leste da área apresenta elevada declividade nas proximidades da zona que margeia a represa, chegando a atingir $90 \%$ de caimento para sul.

A área à jusante da indústria apresenta planície constituída pela zona que margeia a represa.

\subsubsection{Potenciometria}

Dois eventos de monitoramento foram realizados em 13 de novembro de 1997 e 16 de maio de 1998, tendo sido efetuadas medidas para determinação dos níveis d'água nos PMs.

As medidas foram realizadas tomando por base a boca dos poços e foram relacionadas às cotas dos PMs para determinação da potenciometria local nas duas datas consideradas. Os resultados obtidos são apresentados no Apêndice 02.

As Figuras 11 a e $11 \mathrm{~b}$ apresentam os mapas potenciométricos confeccionados a partir da correlação entre as cotas dos PMs determinadas a partir do levantamento planialtimétrico e os valores dos níveis d'água nos PMs nos dois eventos de monitoramento realizados. O espaçamento das curvas indicadas no mapa obedece o intervalo de $10,0 \mathrm{~m}$. 
Figura 11 a - Mapa Potenciométrico. Dados de 13 de novembro de 1997

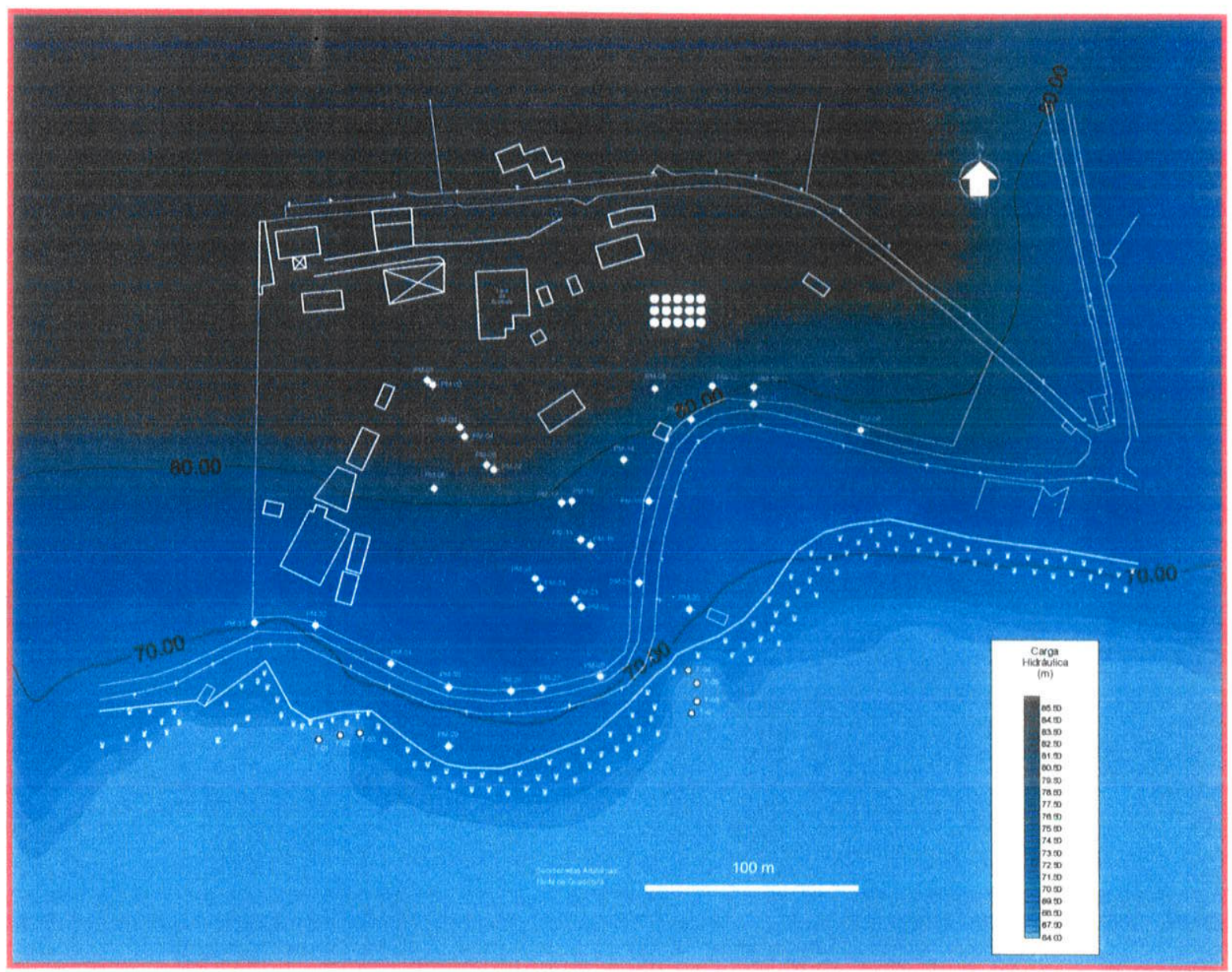


Figura 11 b - Mapa Potenciométrico. Dados de 16 de maio de 1998

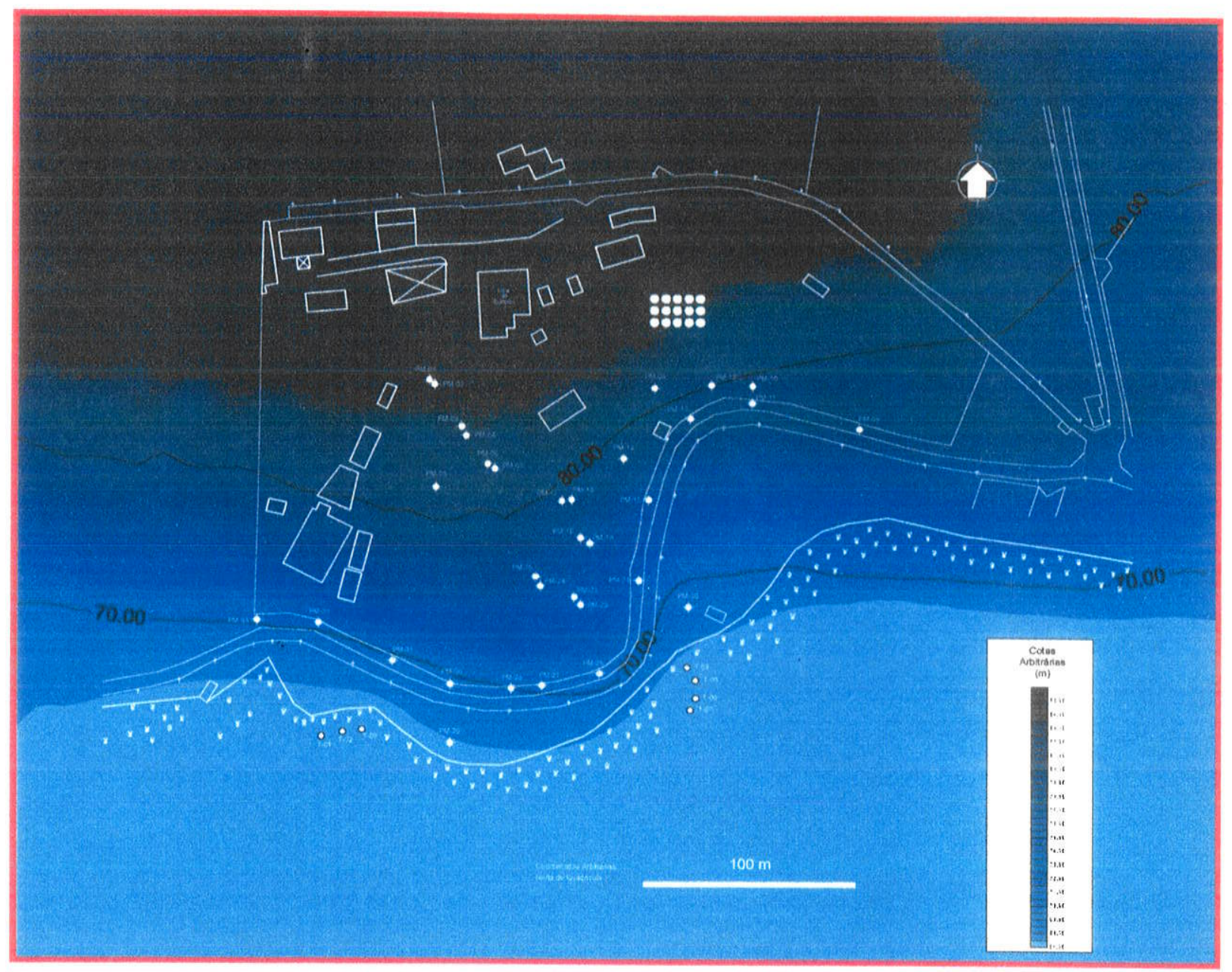

Em ambos os mapas potenciométricos apresentados percebe-se a existência de divisor de águas situado na porção norte da área, condicionando o fluxo da água subterrânea para sul e sudeste, em direção à represa.

O espaçamento entre as linhas equipotenciais é semelhante nos dois eventos apresentados. Há contudo, um deslocamento das linhas equipotenciais (observar linhas de $80 \mathrm{~m}$ representadas nas Figuras 11 a e 11 b) na porção nordeste da área, indicando aumento da potenciometria nesta região em maio de 1998 com relação à novembro de 1997. 
As instalações da indústria estão contidas no domínio potenciométrico central da área, com fluxo da água subterrânea para sudeste ou sul, preferencialmente para este último sentido pelo estreitamento das linhas equipotenciais na região central dos mapas.

Para efeito de cálculos foram considerados os gradientes hidráulicos preponderantes na faixa central do mapa, na direção norte sul.

Em novembro de 1997, a distância mínima medida no mapa potenciométrico entre as linhas representativas de $80 \mathrm{~m}$ e $70 \mathrm{~m}$ foi de $60,8 \mathrm{~m}$, nas proximidades dos PMs 05 e 32, e conferiram ao aquífero um gradiente hidráulico local de aproximadamente $14,7 \%$, o maior valor identificado no periodo. Acompanhando este sentido de fluxo, no entanto, a atenuação do gradiente hidráulico se dá a jusante da área, dentro dos limites da indústria, onde o gradiente atingiu valor igual a $7,5 \%$.

A configuração do mapa potenciométrico em maio de 1998 indicou aumento no valor do gradiente hídráulico para $15,4 \%$ na mesma área central considerada no mapa de novembro de 1997. A jusante da área, ainda dentro dos limites da indústria, foi identificado aumento do gradiente hidráulico com relação ao periodo anterior de monitoramento neste local, para cerca de $13,6 \%$. 


\subsubsection{Cálculo da Veloci dade de Fluxo da Água Subterrânea}

Considerando os valores de condutividade hidráulica apresentados no item 7.1 .4 , a porosidade efetiva para fluxo (10\%, de acordo com Fetter, 1988) utilizada na determinação do aporte de água subterrânea na zona que margeia a represa a partir dos testes dos tambores (item 7.1.5) e os valores de gradiente hidráulico determinados no item 7.1.7, foram estimadas as velocidades de fluxo da água subterrânea através da relação estabelecida por Darcy (Freeze, 1979).

As velocidades estimadas para o fluxo da água subterrânea estão apresentadas no Apêndice 03 , subdivididas nas duas datas de amostragem dos PMs e considerando os máximos e mínimos valores de gradientes hidráulicos calculados para cada data a partir dos mapas potenciométricos.

As velocidades calculadas a partir dos dados obtidos nos dois eventos de monitoramento realizados enquadram-se em um intervalo contido entre os valores extremos de $0,30 \mathrm{~cm} / \mathrm{dia}$ e $16,37 \mathrm{~cm} / \mathrm{dia}$, dependentes da variação do gradiente hidráulico averiguado no período.

Por estarem instalados nas proximidades de um talude (representado no mapa topográfico da Figura 09), os PMs 08,14 e 24 apresentaram os maiores valores para condutividade hidráulica e, consequentemente, resultando nas maiores velocidades de fluxo calculadas. Geologicamente, este poços não interceptam camadas ou lentes que possam constituir caminho preferencial de fluxo, possuindo homogênea descrição (ver Perfis no Apêndice 01) de argila com areia fina a média, micácea.

Os PMs 17, 18, 19, 22 e 23 apresentam valores médios de velocidade da água subterrânea para o local, fato condizente com a posição planialtimétrica dos PMs, em área plana, entre taludes e com atenuação dos valores de condutividade hidráulica. 
O PM-12 apresentou baixo valor de condutividade hidráulica, resultando por sua vez, em velocidade de fluxo da água subterrânea muito inferior às demais calculadas. A descrição geológica do poço (ver Apêndice 01) indica litologia semelhante à dos demais poços avaliados, no entanto, a velocidade de fluxo calculada indica a presença de materiais argilosos, pouco condutivos, possivelmente nas proximidades do poço. Esta pode ser considerada uma hipótese viável para o valor de velocidade de fluxo estimado no local, bem como a colmatação do filtro durante o ensaio de condutividade.

A partir dos mapas potenciométricos apresentados nas Figuras 11 a e $11 \mathrm{~b}$, estima-se em 170,4 m a distância mínima, medida na direção NW-SE, entre a fábrica de tintas da indústria e a zona que margeia a represa. Adotando-se os valores extremos calculados para velocidade linear da água subterrânea, obtém-se o tempo mínimo de 2,85 anos e o tempo máximo de 155,62 anos para a água percorrer o trajeto considerado.

Estes valores, no entanto, representam situações críticas de fluxo, ora pela presença de elevados valores de gradiente hídráulico e condutividade hidráulica condicionados pela topografia local, ora pela presença de possivel litologia pouco condutiva, distinta do padrão litológico descrito nas sondagens efetuadas na área.

Considerando que a água subterrânea percorre dentro da área avaliada uma velocidade média, foram tomados todos os valores calculados para as duas datas distintas de monitoramento, tendo sido obtidas velocidades médias (aritméticas) iguais a $5,67 \mathrm{~cm} /$ dia, referentes aos dados de 13/11/1997, e $7,40 \mathrm{~cm} /$ dia referentes aos dados de 16/05/1998 para o fluxo da água subterrânea.

Os valores médios de velocidade fluxo indicam, por sua vez, que a água subterrânea deve percorrer a distância entre a fábrica de tintas da indústria e a zona que margeia a represa de Guarapiranga em um intervalo de tempo compreendido entre 8,23 e 6,30 anos.

Convém salientar que as velocidades aqui apresentadas são calculadas, havendo a necessidade de utilização de um traçador para determinação da velocidade real de fluxo da água subterrânea. 


\subsection{Modelo Conceitual de Transporte de Contaminantes}

\subsubsection{Análises Químicas de Amostras de Água}

\subsubsection{Poços de Monitoramento}

Os 33 PMs instalados na área de estudos foram amostrados em três eventos datados de 21 de março de 1997, 10 de dezembro de 1997 e 16 de maio de 1998 e as amostras foram enviadas ao laboratório para realização de análises de acordo com a metodologia apresentada.

O Apêndice 04 apresenta os resultados das análises para determinação de Benzeno, Tolueno e Xilenos Totais, identificados respectivamente como BTX.

O Apêndice 05 apresenta os resultados das análises para determinação dos compostos organoclorados.

A determinação da solubilidade específica de um contaminante presente em uma mistura é feita a partir da relação entre a solubilidade do contaminante puro e sua fração molar dentro da mistura.

A partir das frações molares dos contaminantes, por sua vez, torna-se possivel estimar a presença destes em fases residuais, no aquifero, permitindo desta forma a adoção de técnicas apropriadas de remediação.

$\mathrm{Na}$ área de estudos, como o cenário de contaminação foi gerado a partir de um acidente na área de fabricação, não são conhecidas as frações molares de cada contaminante na mistura final que entrou em contato com o solo e posteriormente migrou para a água subterrânea.

Desta forma, torna-se impraticável a determinação das frações molares dos contaminantes existentes na mistura final 


\subsubsection{Tambores (Seepage)}

As amostras coletadas a partir dos testes dos tambores nas margens da represa foram encaminhadas ao laboratório para determinação das concentrações dos compostos de interesse.

O Apêndice 06 apresenta os resultados das análises para determinação de BTX nas amostras coletadas dos tambores nos dois eventos de monitoramento.

O Apêndice 07 apresenta os resultados para determinação de compostos organoclorados nas amostras provenientes dos tambores.

Na primeira bateria de testes, o Tambor T-03 não apresentou amostra para ser analisada. Amostras dos Tambores T-04 e T-05 foram analisadas mesmo com 0 pequeno volume apresentado e não indicaram contaminação, bem como as análises dos demais tambores.

$\mathrm{Na}$ segunda bateria de testes, as amostras dos Tambores que apresentaram pequenos volumes, insuficientes à determinação precisa das concentrações pelos métodos de análises adotados, foram descartadas. As amostras analisadas não indicaram contaminação.

\subsubsection{Determinação das Plumas de Contaminação}

A partir das concentrações de contaminantes obtidas através das campanhas de amostragens dos PMs e da instalação dos Tambores, foram confeccionados mapas de isoconcentrações para os contaminantes de interesse ao longo do tempo, de forma a permitir a caracterização evolutiva do cenário de contaminação identificado no local.

As plumas de concentração para os compostos BTX são apresentadas nas Figuras 12 ( $a, b$ e $c), 13$ ( $a, b$ e c) e 14 ( $a, b$ e $c$ ). 


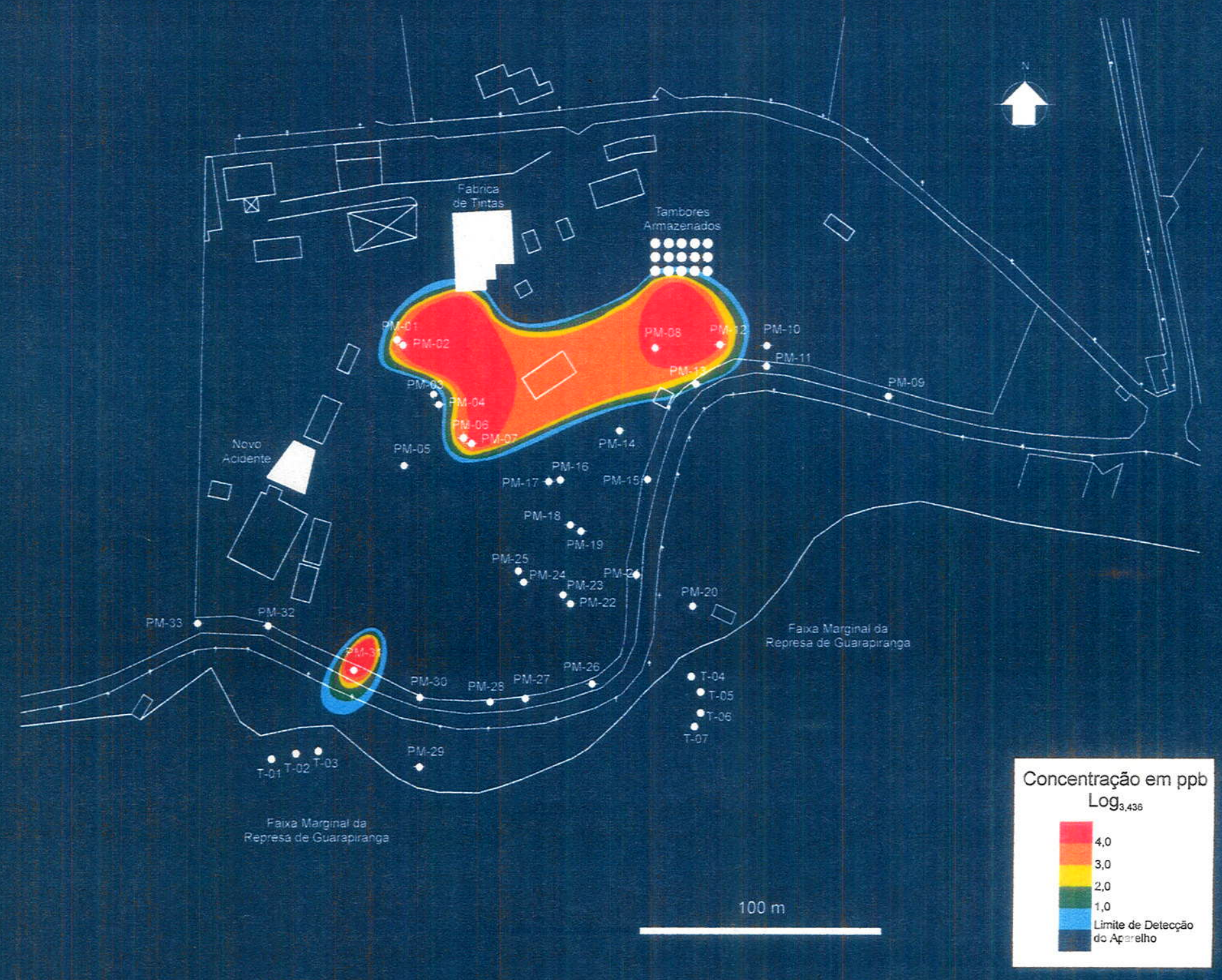



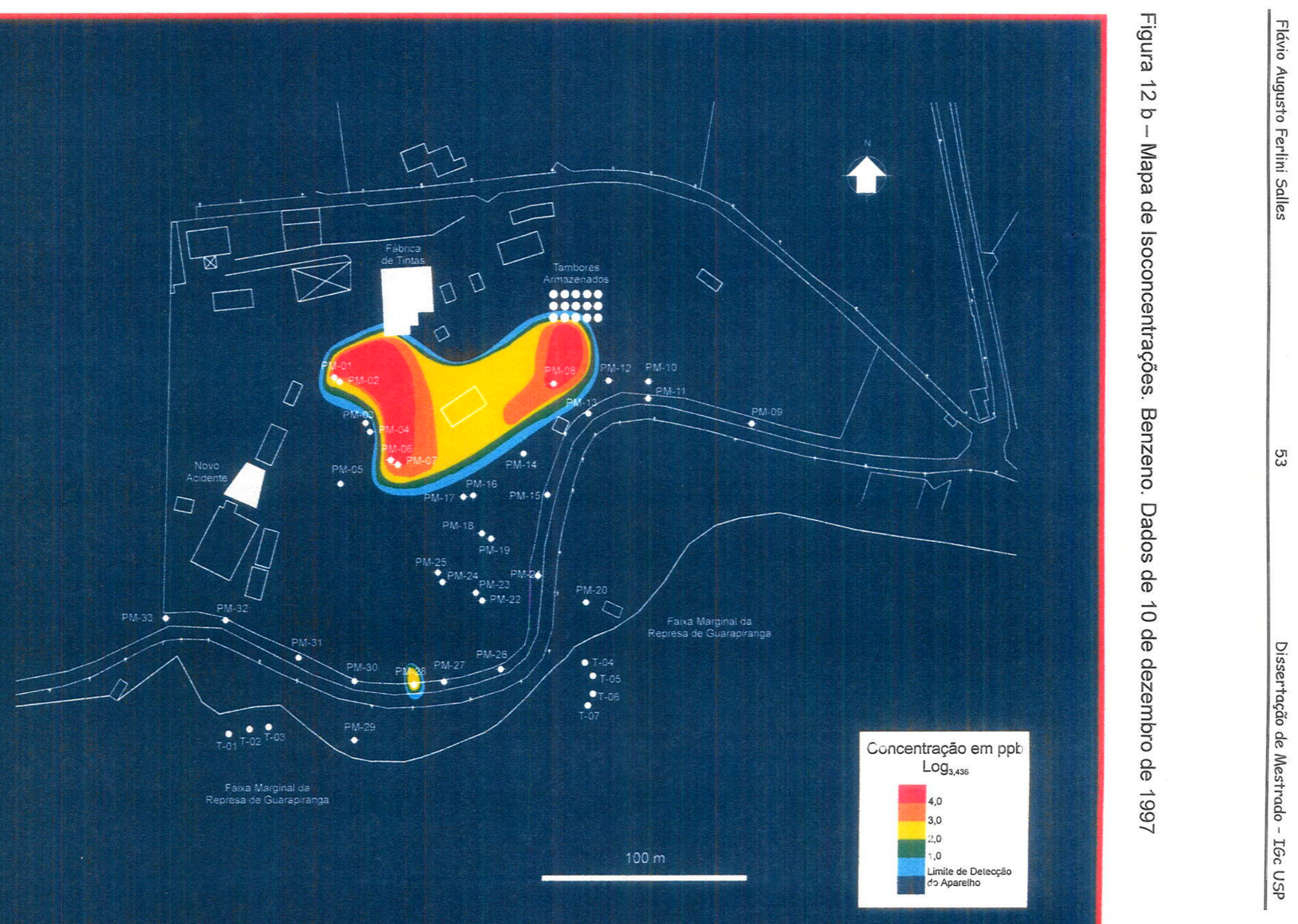

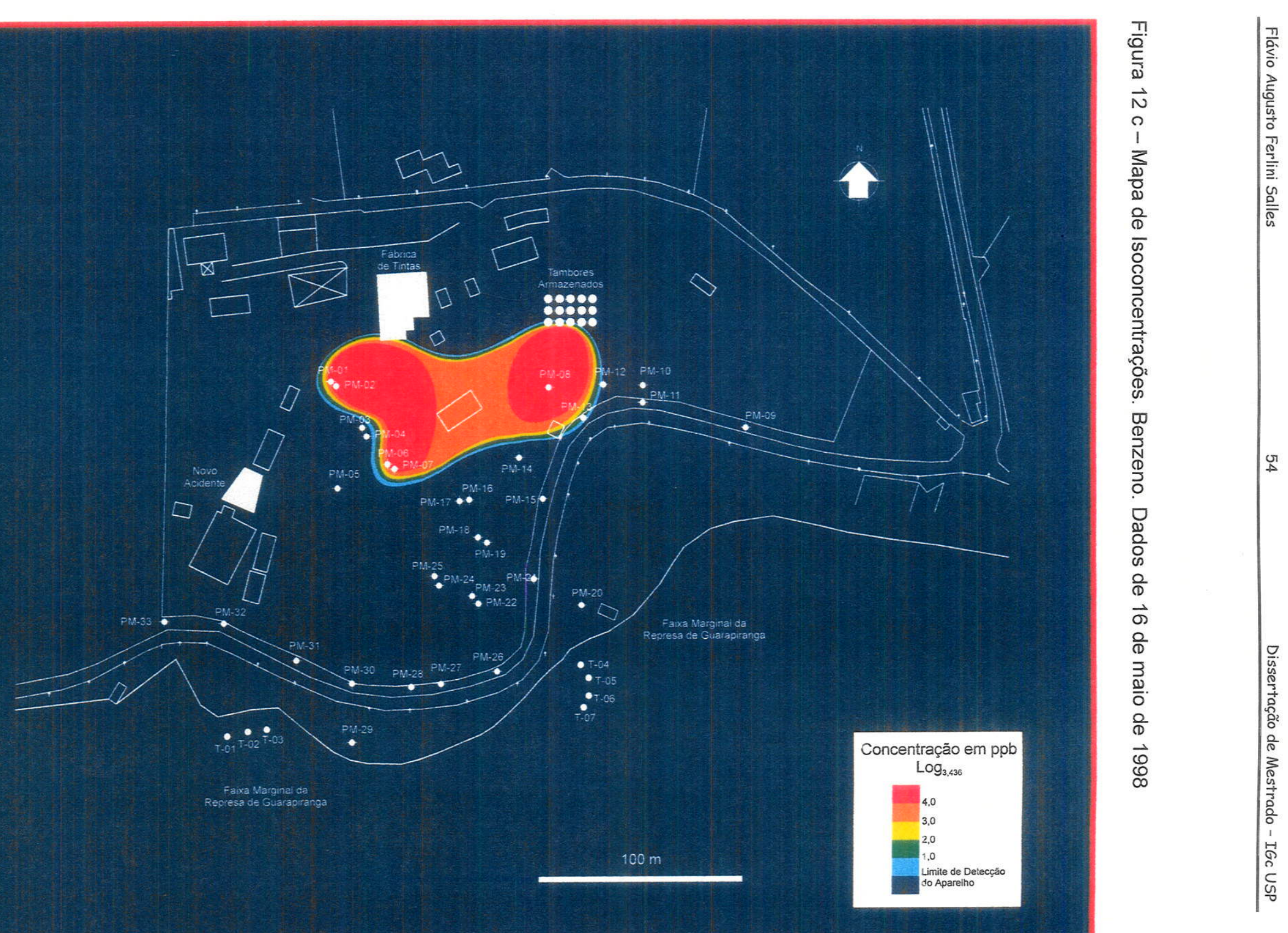

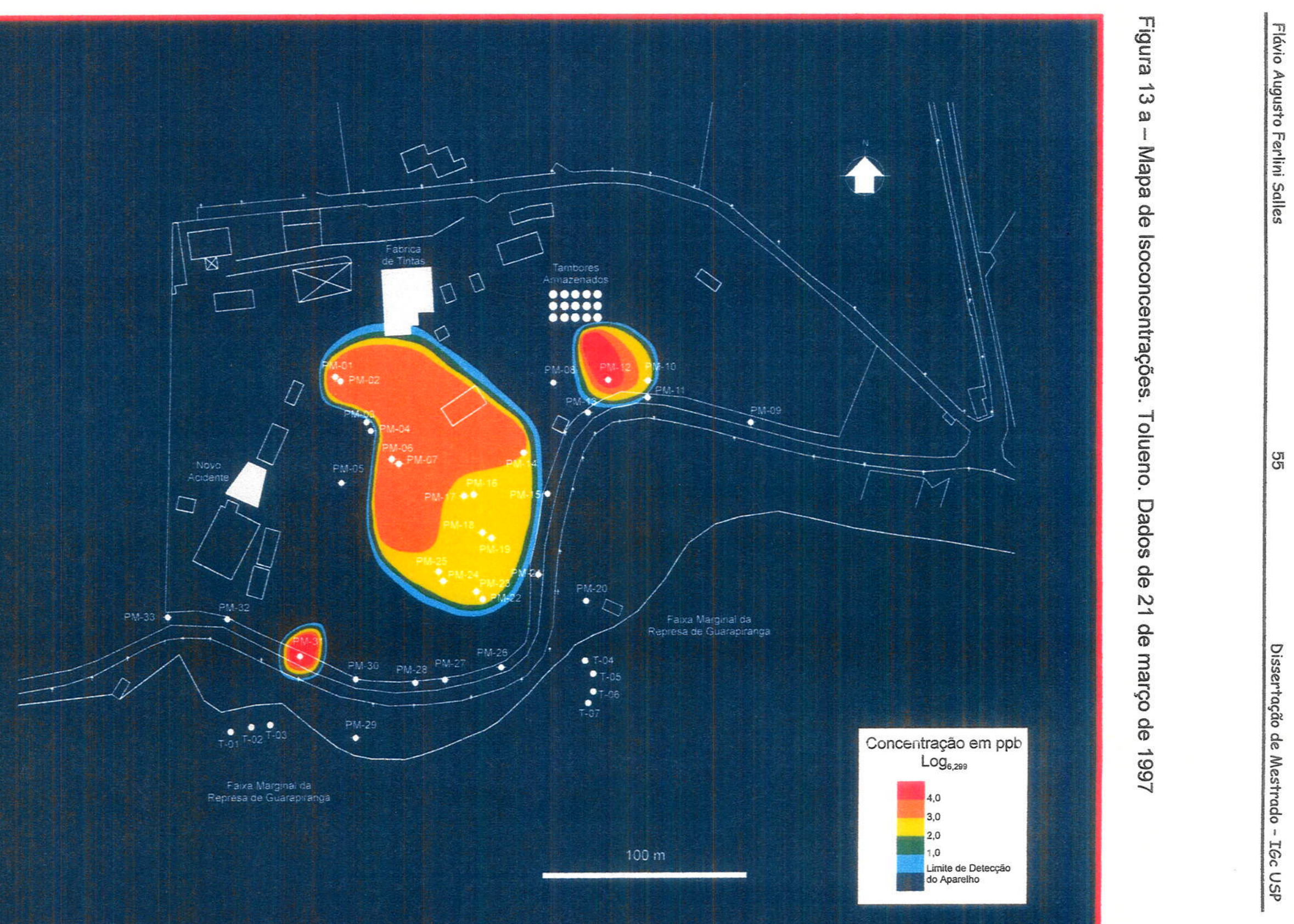

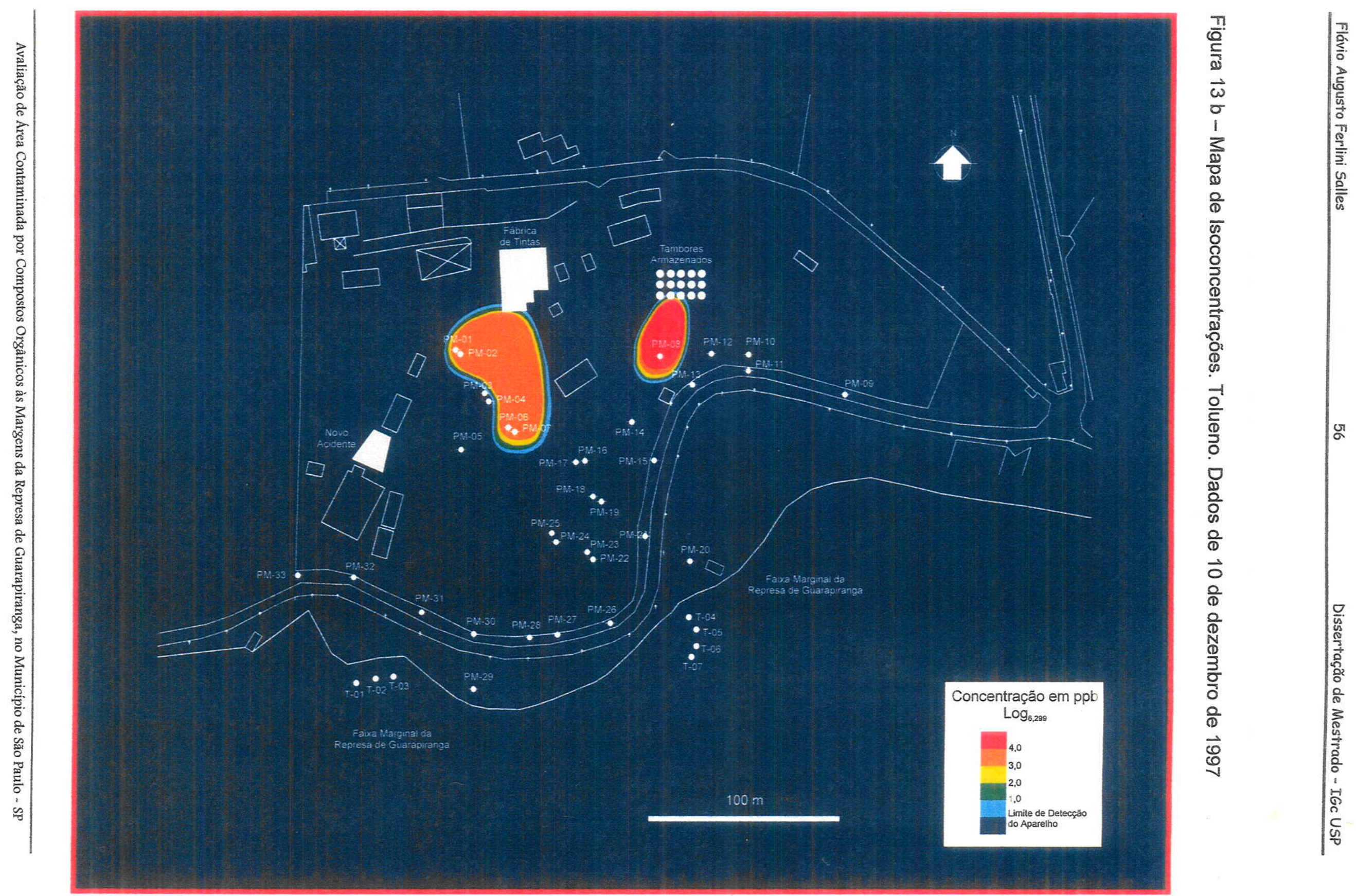


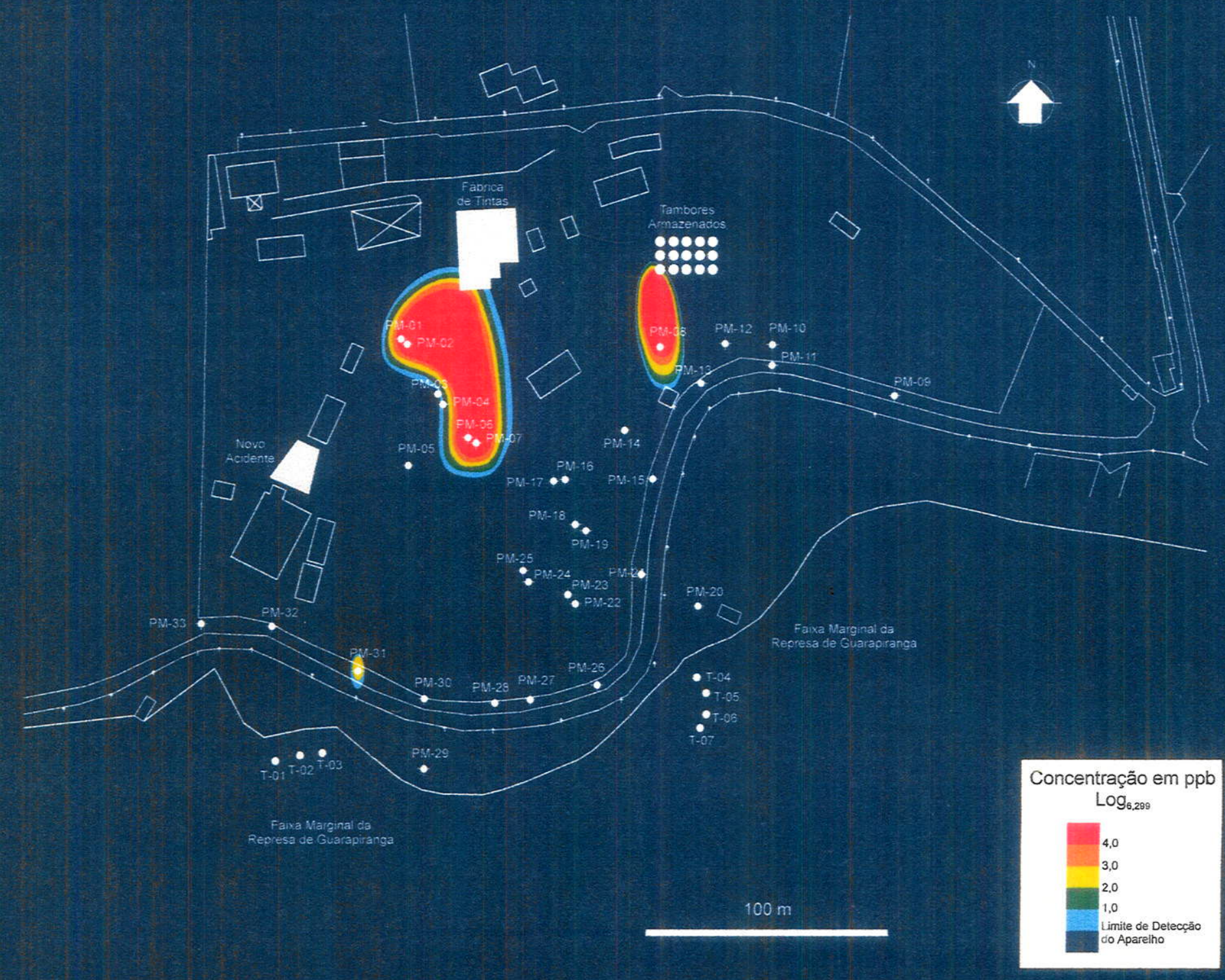

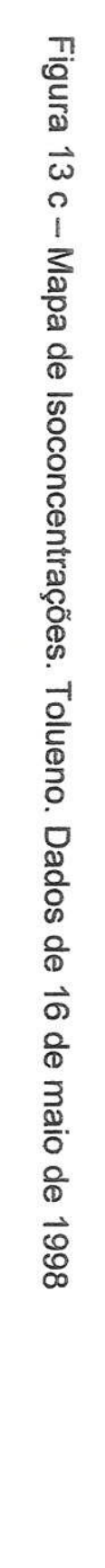




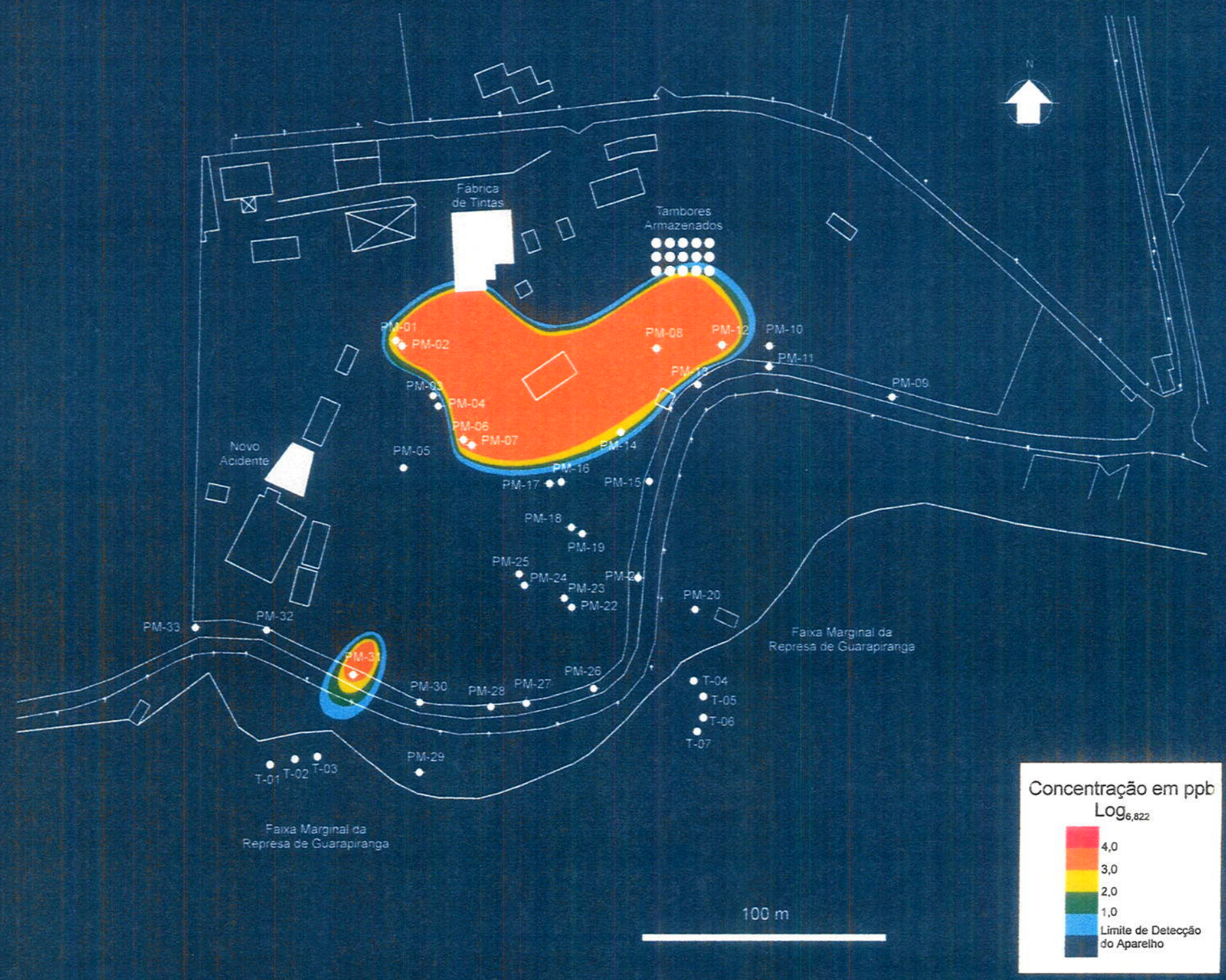




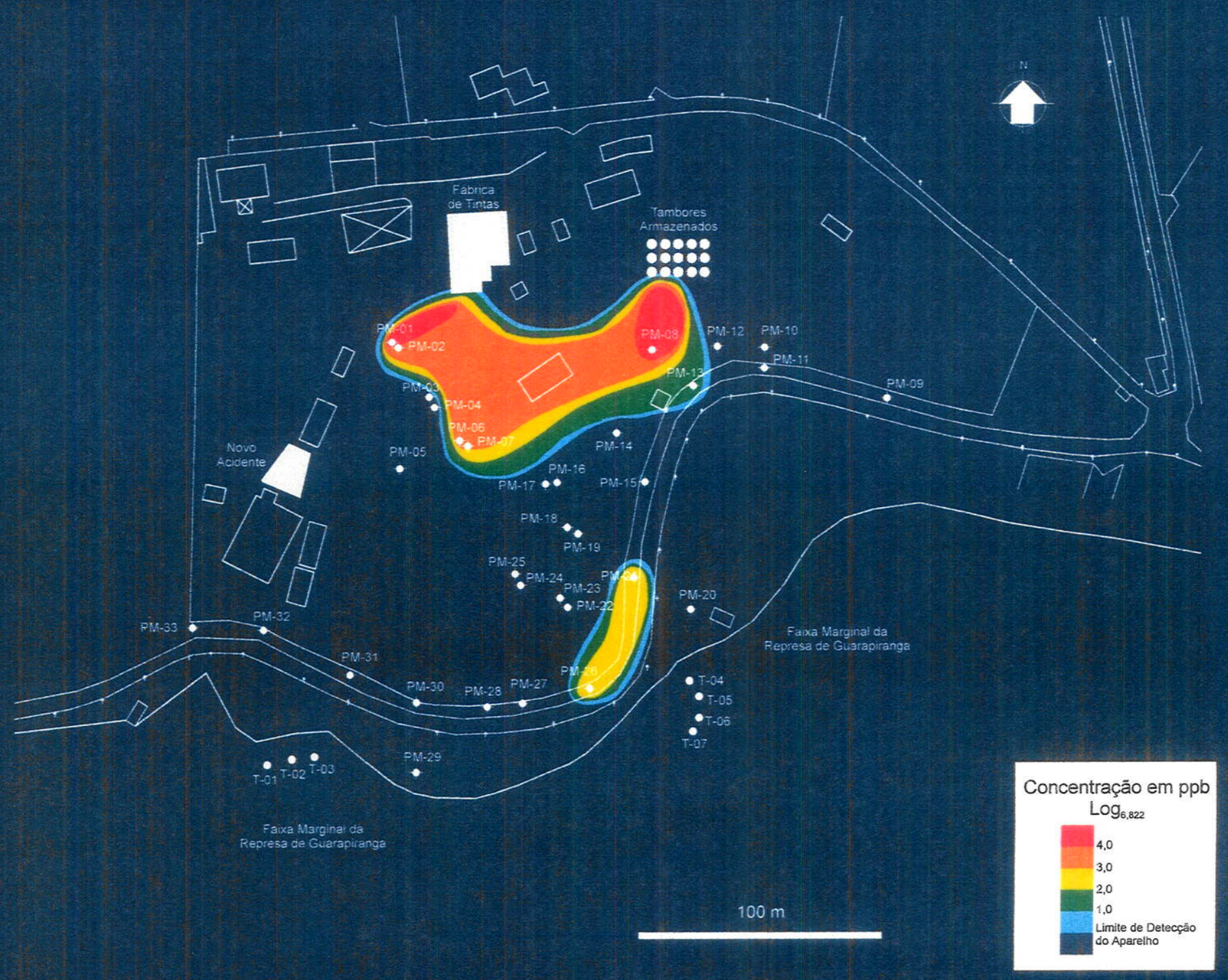



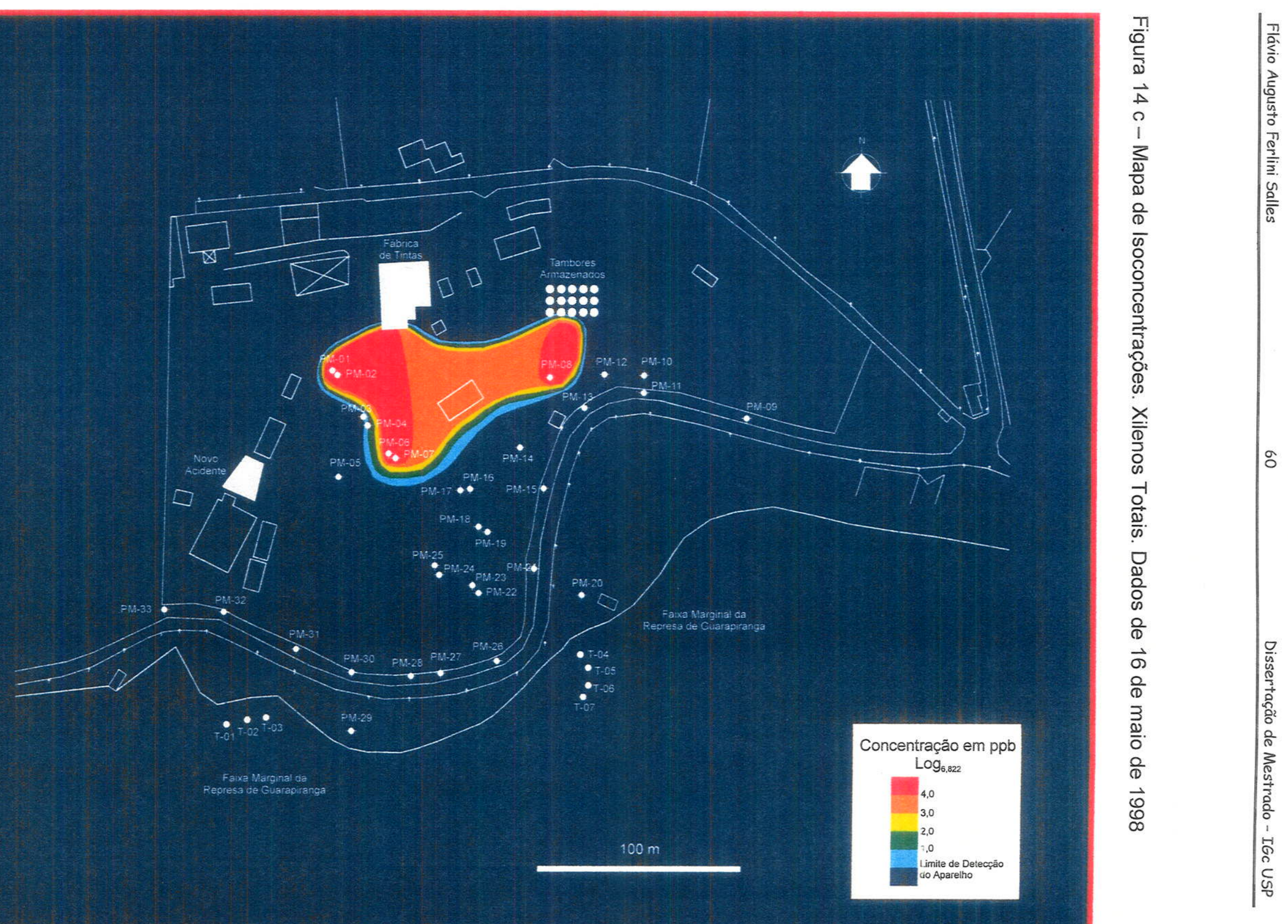
Para os compostos organoclorados foram consideradas as análises dos compostos 1,2 Dicloroetano e 1,1,1 Tricloroetano para construção das plumas de contaminação. Os mapas de isoconcentrações dos compostos organoclorados são apresentados nas Figuras 15 ( $a, b$ e $c)$ e 16 ( $a, b$ e $c)$. 

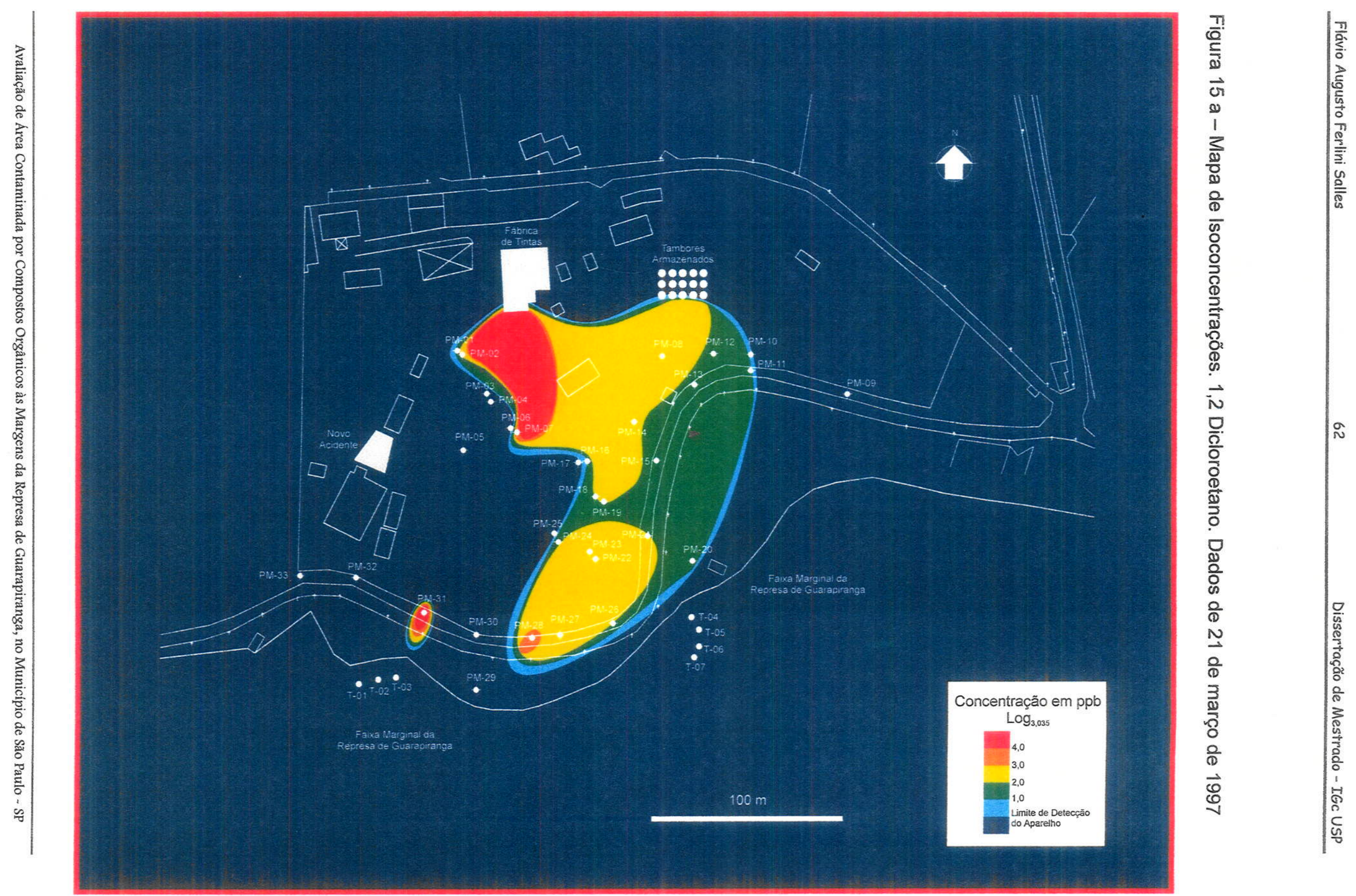

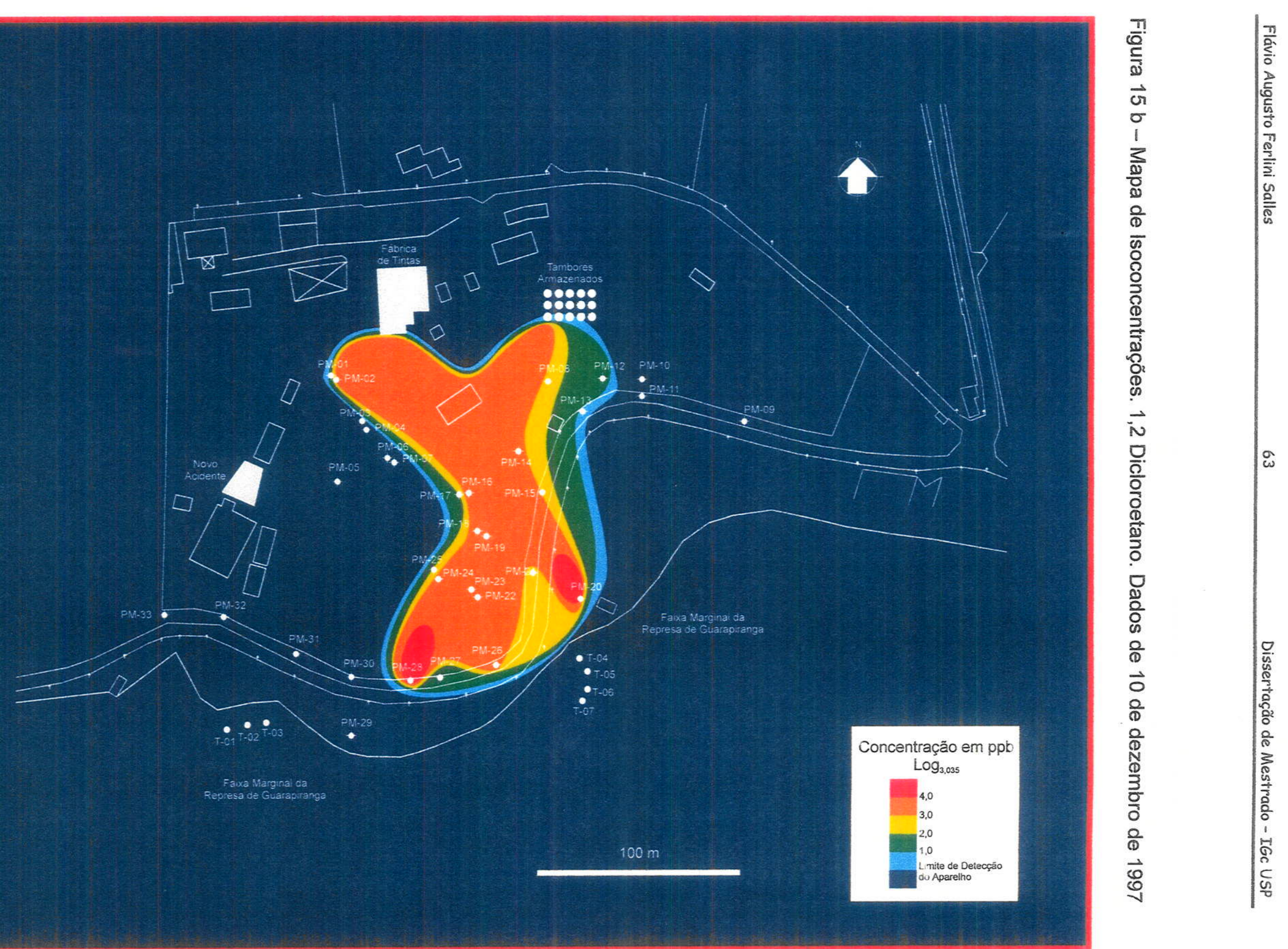

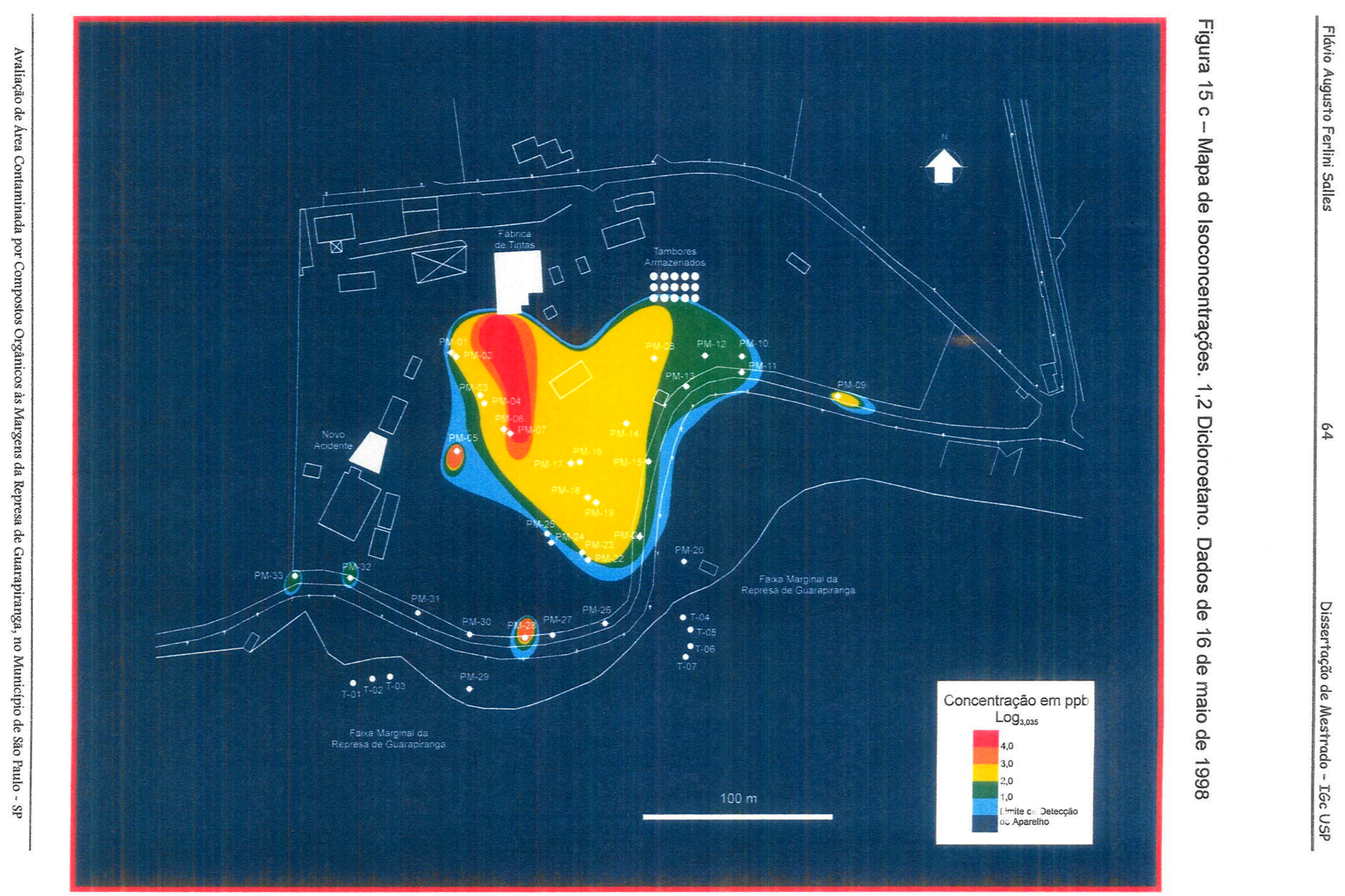


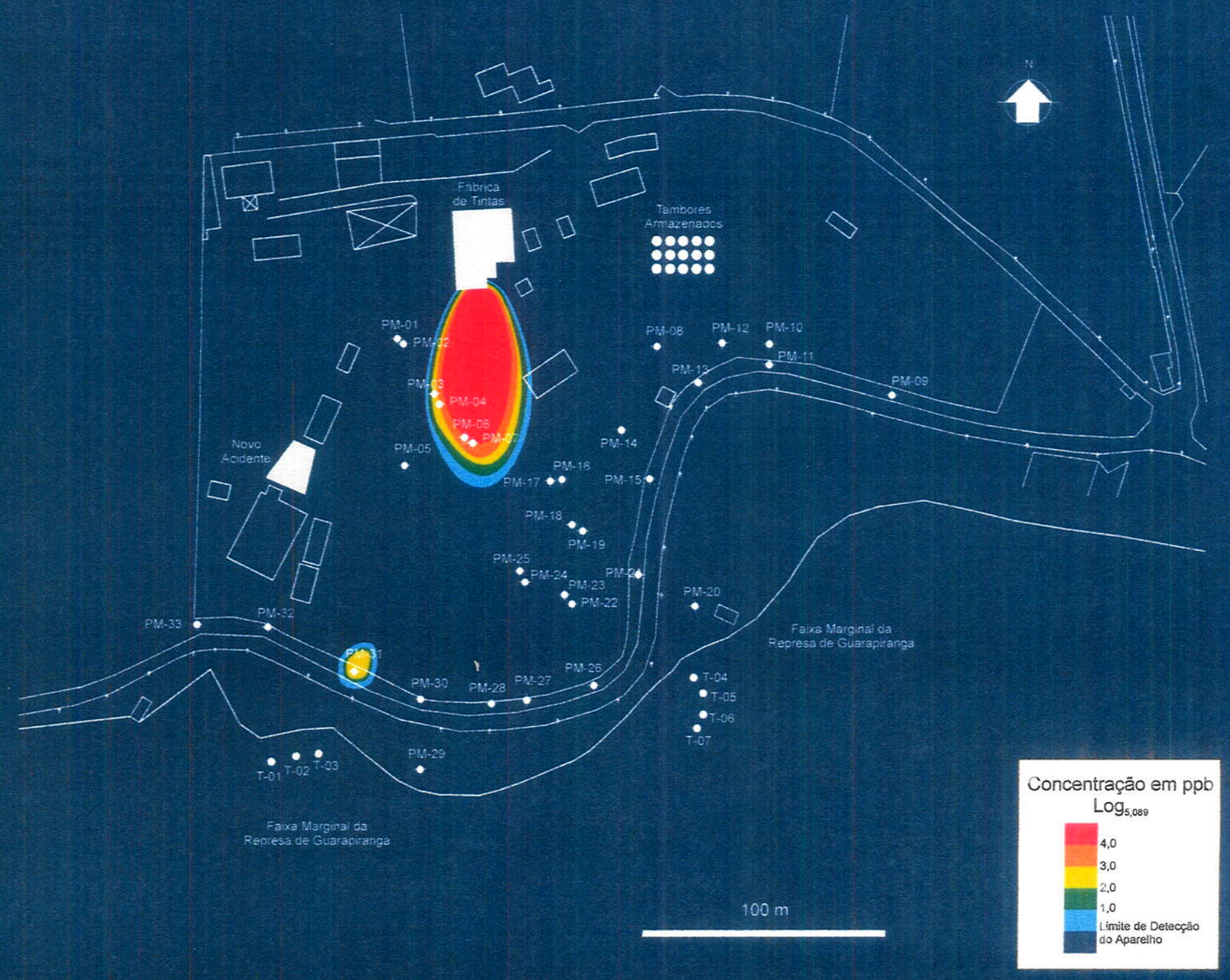



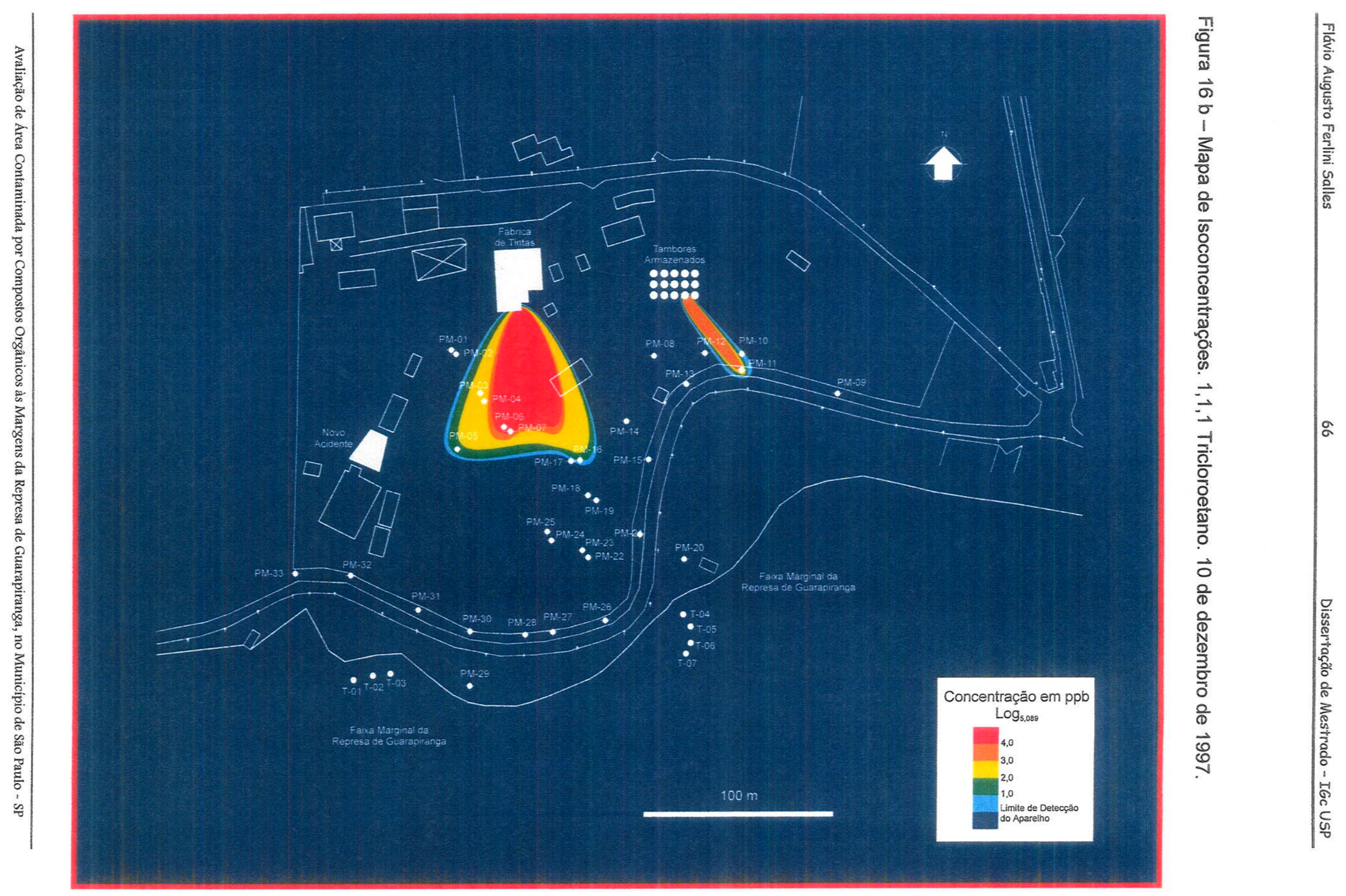

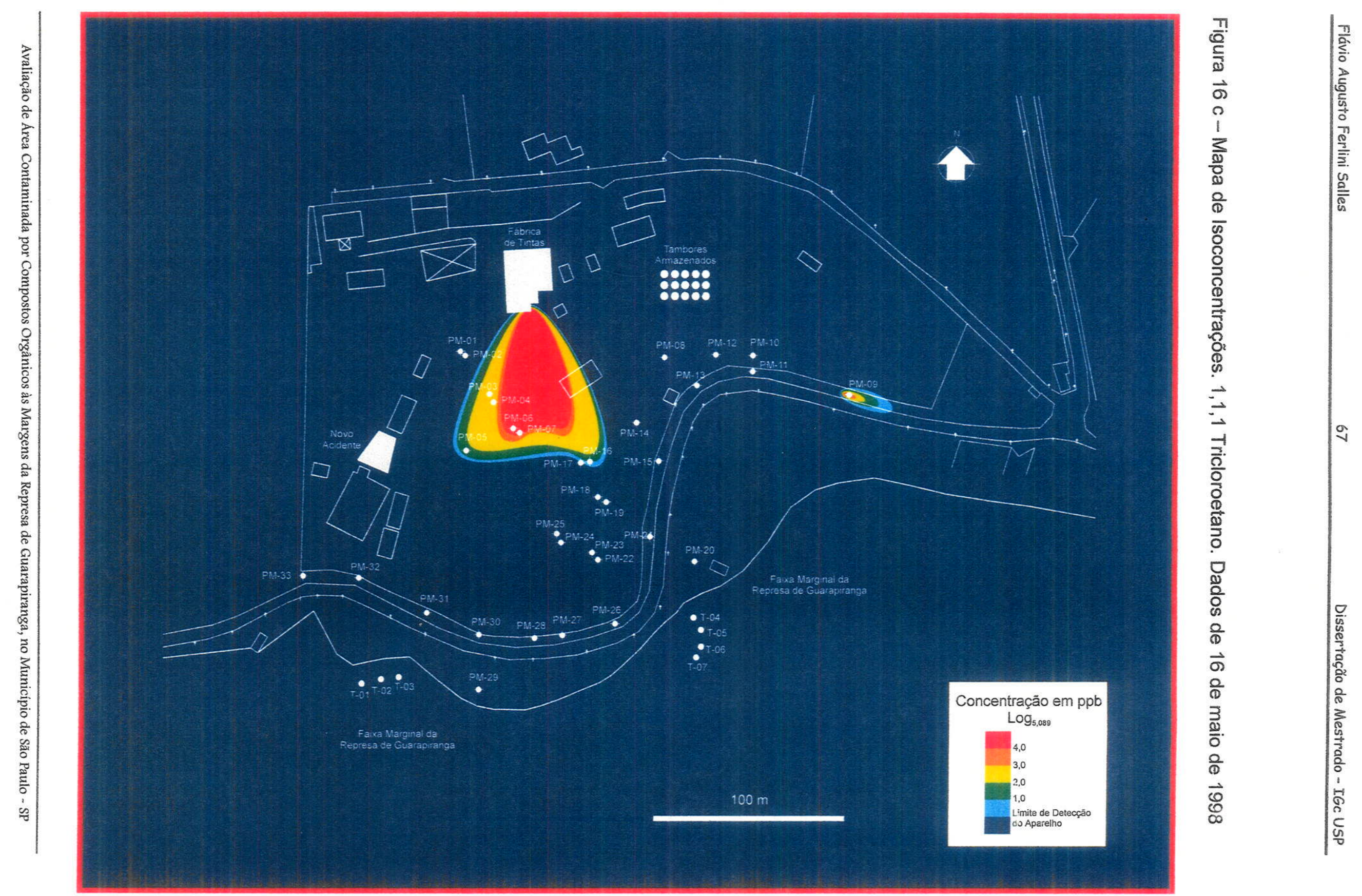
As plumas de contaminação indicam, de uma maneira geral, três áreas fontes de contaminação a partir dos mapas de março de 1997. As três áreas fontes de contaminação citadas são definidas como A - Fábrica de Tintas (Local da Explosão), B - Tambores Armazenados Inadequadamente e C - Tanque de Refrigeração (Local onde houve derramamento acidental de contaminantes, próximo à Área de Recuperação de Solventes).

Inicialmente, separam-se as áreas A e B pela correlação das plumas de contaminação com os mapas potenciométricos apresentados nas Figuras 11 a e $11 \mathrm{~b}$, indicando que é improvável a migração de concentrações de contaminantes da área $\mathbf{A}$ para $\mathbf{B}$ e vice-versa pela configuração da potenciometria local.

Com relação à área $\mathrm{C}$, descrita por funcionários da indústria como alvo de derramamentos acidentais de solventes, a interpretação dos dados permite supor uma sequência de eventos caracterizada por:

- Março de 1997 - pulso inicial de contaminantes detectado pela presença de concentrações no PM-31 em todas as plumas analisadas;

- Dezembro de 1997 - Controle da situação de contaminação, evidenciada pela ausência de contaminantes nas proximidades da área $\mathbf{C}$ no segundo evento de amostragens. A concentração de Benzeno no PM-28 (Figura 12 b) pode ser atribuida à contaminação cruzada durante 0 processo de amostragem ou ainda alteração dos resultados por violação do poço. A concentração de 1,2 Dicloroetano no mesmo PM-28 (Figura 15 b), por sua vez, não é atribuída à área fonte $\mathrm{C}$, tanto pela configuração da potenciometria local quanto pela distribuição da pluma de contaminação de 1,2 Dicloroetano em dezembro de 1997, que indica uma migração de contaminantes de áreas a montante;

- Maio de 1998 - Novo derramamento, provavelmente de pequenos volumes, caracterizado pela presença de 1,2 Dicloroetano nos PMs 32 e 33.

A configuração inicial e 0 desenvolvimento temporal das plumas de contaminação de BTX obedecem padrões semelhantes, possuindo as plumas de Benzeno um menor espalhamento, possivelmente em virtude de sua maior capacidade de volatilização. 
Com relação às pluma de BTX supõem-se três fases distintas de contaminação:

- Março de 1997 - Fase inicial caracterizada pelo aporte de contaminantes provenientes das áreas A e B. As plumas de contaminação nesta data (Figuras 12 a, 13 a e 14 a) indicam possivel correlação entre os contaminantes em baixas concentrações provenientes das duas áreas. Tanto a união quanto a independência das plumas provindas das áreas A e B são hipóteses plausíveis em virtude da inexistência de malha mais adensada de poços entre as duas áreas;

- Dezembro de 1997 - Nesta fase, percebe-se atenuação das concentrações nas bordas das plumas (Figuras $12 \mathrm{~b}, 13 \mathrm{~b}$ e $14 \mathrm{~b}$ ), sugerindo o controle do aporte de contaminantes a montante e 0 ativo processo de biodegradação. Com relação à pluma de Xilenos (Figura 14 b), os indícios de contaminação apresentados nos PMs 21 e 25 podem ser atribuídos à contaminação cruzada durante o processo de amostragem ou ainda à alteração dos resultados por violação dos PMs, uma vez que estas concentrações não guardam relação com a pluma de contaminação original de montante. Esta interpretação se repete com relação à concentração de Benzeno no PM-28 em dezembro de 1997;

- Maio de 1998 - Novo aporte de contaminantes provenientes das áreas A e B caracterizado pelo aumento nos valores máximos de contaminantes identificados em cada pluma de contaminação (Figuras $12 \mathrm{c}, 13 \mathrm{c}$ e $14 \mathrm{c}$ ). 
Com relação às plumas de contaminação referentes ao 1,2 Dicloroetano, encontra-se:

- Março de 1997 - A pluma (Figura 15 a) deste contaminante é extensa em área, caracterizando a sua persistência com relação aos processos de biodegradação. A migração da pluma acompanha o sentido de fluxo estabelecido para o local, preferencialmente $\mathrm{N}-\mathrm{S}$, o que pode explicar a inexistência de contaminante nas amostras dos tambores T-04 à T-07;

- Dezembro de 1997 - Migração da pluma inicial identificada em março do mesmo ano, caracterizada pela atenuação das concentrações nas proximidades das áreas fontes e aumento generalizado das concentrações no centro da pluma (Figura 15 b). Redução da velocidade de migração nas zonas a jusante, evidenciada pelo não deslocamento da borda da pluma e acúmulo gradativo das maiores concentrações provindas de áreas a montante na zona de redução do gradiente hidráulico (Figuras 11 a e 11 b);

- Maio de 1998 -Aporte de contaminantes a partir da área fonte A evidenciada pelo aumento de contaminações a montante (Figura $15 \mathrm{c}$ ). Em contrapartida, $O$ aporte de contaminantes a partir da área $B$, identificado a partir das plumas de BTX, não é registrado para 1,2 Dicloroetano, havendo nas proximidades da área fonte citada um decréscimo das concentrações de contaminante. A jusante, percebe-se redução das concentrações e da extensão da pluma, ocasionadas por provável atuação dos processos de biodegradação e volatilização, em área com menores velocidades de migração. 
Com relação às pluma de contaminação delimitadas a partir das concentrações de 1,1,1 Tricloroetano:

- Março de 1997 -Dentre as plumas de contaminação delimitadas, este contaminante é o único que não apresenta evidências de aporte de contaminante a partir da área B (Figura 16 a). A pluma de contaminação de 1,1,1 Tricloroetano apresenta menor distribuição em área e é controlada pelo regime de fluxo local com migração preferencial no sentido $\mathrm{N}-\mathrm{S}$. Concentrações no PM-31 indicam a existência de contaminantes provenientes da área C;

- Dezembro de 1997-Diferenciando-se das demais plumas de contaminação apresentadas, é identificado aporte de contaminantes provenientes da área B (Figura 16 b). Esta aparente incongruência é possivelmente relacionada à presença de baixas concentrações deste contaminante nos tambores armazenados na área B, não sendo identificadas nas análises de março de 1997 a frente inicial de contaminação, que por sua vez sofreu lenta migração, sendo identificada em dezembro.

- Maio de 1998 - O contaminante mostra-se pouco móvel na região central (Figura $16 \mathrm{c}$ ), havendo distribuição semelhante das curvas de isoconcentração e não indicando novo aporte de contaminantes das áreas fontes. A pluma proveniente da área B mostra mobilidade e apresenta-se reduzida, não havendo indícios de novo aporte de contaminantes como determinado nas outras plumas demarcadas, provavelmente resultado da ausência deste contaminante nas misturas contidas nos tambores armazenados irregularmente. 


\subsubsection{Determinação de Parâmetros de Retardamento}

\subsubsection{Coeficiente de Dis tribuição $\left(K_{d}\right)$ Para o Benzeno}

A partir de amostras de solo coletadas na área de estudos durante o processo de sondagens para instalação dos PMs, foram determinados os parâmetros apresentados na Tabela 05.

O contaminante utilizado como traçador para determinação do $K_{d}$ foi 0 Benzeno, por suas características físico-químicas conhecidas e por sua elevada solubilidade em água.

Tabela 05 - Dados Físico-Químicos Para Determinação de $K_{d}$

\begin{tabular}{|c|c|c|c|c|c|c|c|c|}
\hline Amostra & $\begin{array}{c}\text { Soluçăo } \\
\text { Stock } \\
(\mathrm{mg} / \mathrm{L})\end{array}$ & $\begin{array}{c}\text { Concent. } \\
\text { Inicial } \\
(\mathrm{mg} / \mathrm{L})\end{array}$ & $\begin{array}{c}\text { Massa } \\
\text { Inicial de } \\
\text { Contam. } \\
(\mu \mathrm{g})\end{array}$ & $\begin{array}{c}\text { Concent. } \\
\text { Final na } \\
\text { Agua } \\
(\mathrm{mg} / \mathrm{L})\end{array}$ & $\begin{array}{c}\text { Massa } \\
\text { Final de } \\
\text { Contam. } \\
(\mu \mathrm{g})\end{array}$ & $\begin{array}{c}\text { Massa de } \\
\text { Contam. no } \\
\text { Solo }(\mu \mathrm{g})\end{array}$ & $\begin{array}{c}\text { Massa de } \\
\text { Solo seco } \\
(\mathrm{g})\end{array}$ & $\begin{array}{c}\text { Conc. final no } \\
\text { solo }(\mu \mathrm{g} / \mathrm{g})\end{array}$ \\
\hline 2 & 0,5 & 0,04 & 1,5 & - & - & - & 11,86 & - \\
\hline 4 & 5 & 0,45 & 15 & 0,36 & 11,88 & 3,12 & 17,88 & 0,17 \\
\hline 6 & 50 & 4,54 & 150 & 2,38 & 78,54 & 71,46 & 10,81 & 6,61 \\
\hline 8 & 200 & 18,18 & 600 & 7,69 & 253,77 & 346,23 & 17,72 & 19,53 \\
\hline 10 & 500 & 45,45 & 1500 & 13,54 & 446,82 & 1053,18 & 20,81 & 50,60 \\
\hline
\end{tabular}

As concentrações de contaminante determinadas no solo e na água a partir do Batch Test foram plotadas no Gráfico 02 para determinação da equação da reta média que fornece o valor de $K_{d}$. 
Gráfico 02 - Determinação do Coeficiente de Distribuição $\left(K_{d}\right)$

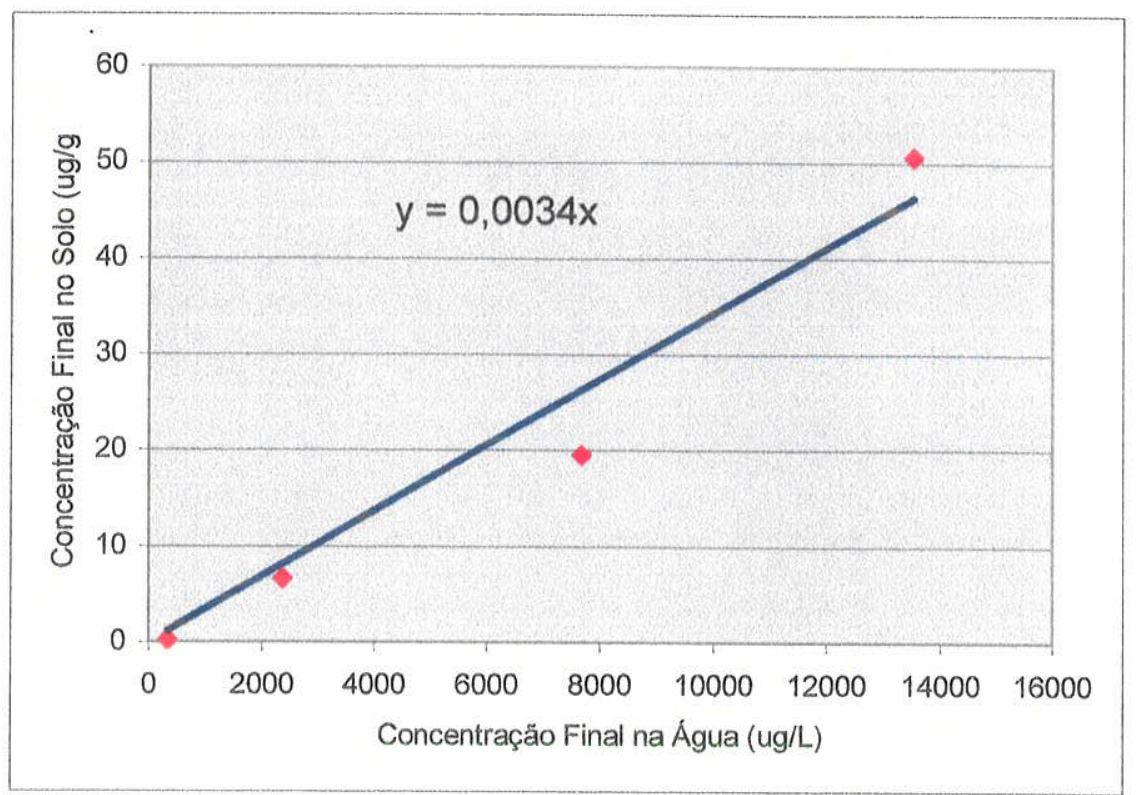

A equação da reta média expressa no Gráfico 02, que representa a razão entre a concentração de Benzeno no solo e a concentração deste contaminante na água, indica um coeficiente de distribuição $\left(K_{d}\right)$ do contaminante para o solo da área estudada igual a $0,0034 \mathrm{~L} / \mathrm{g}$ ou $3,4 \mathrm{~mL} / \mathrm{g}$.

\subsubsection{Determinação do Fator de Retardamento}

A partir do valor de $K_{d}$ obtido para o Benzeno foi determinada a fração de carbono orgânico ( $f_{o c}$ ) no solo estudado, através da relação expressa na Equação 06 e dos valores de partição do contaminante entre solo e água $\left(K_{o c}\right)$ fornecidos por Fetter (1988), sendo $f_{o c}$ aproximadamente igual a 0,035.

A Tabela 06 apresenta os valores fornecidos por Fetter (1988) para Koc dos contaminantes de interesse e, os respectivos valores de $\mathrm{K}_{d}$ calculados. 
Tabela 06 - Valores de $K_{d}$ calculados a partir de $f_{o c}$ e $K_{o c}$

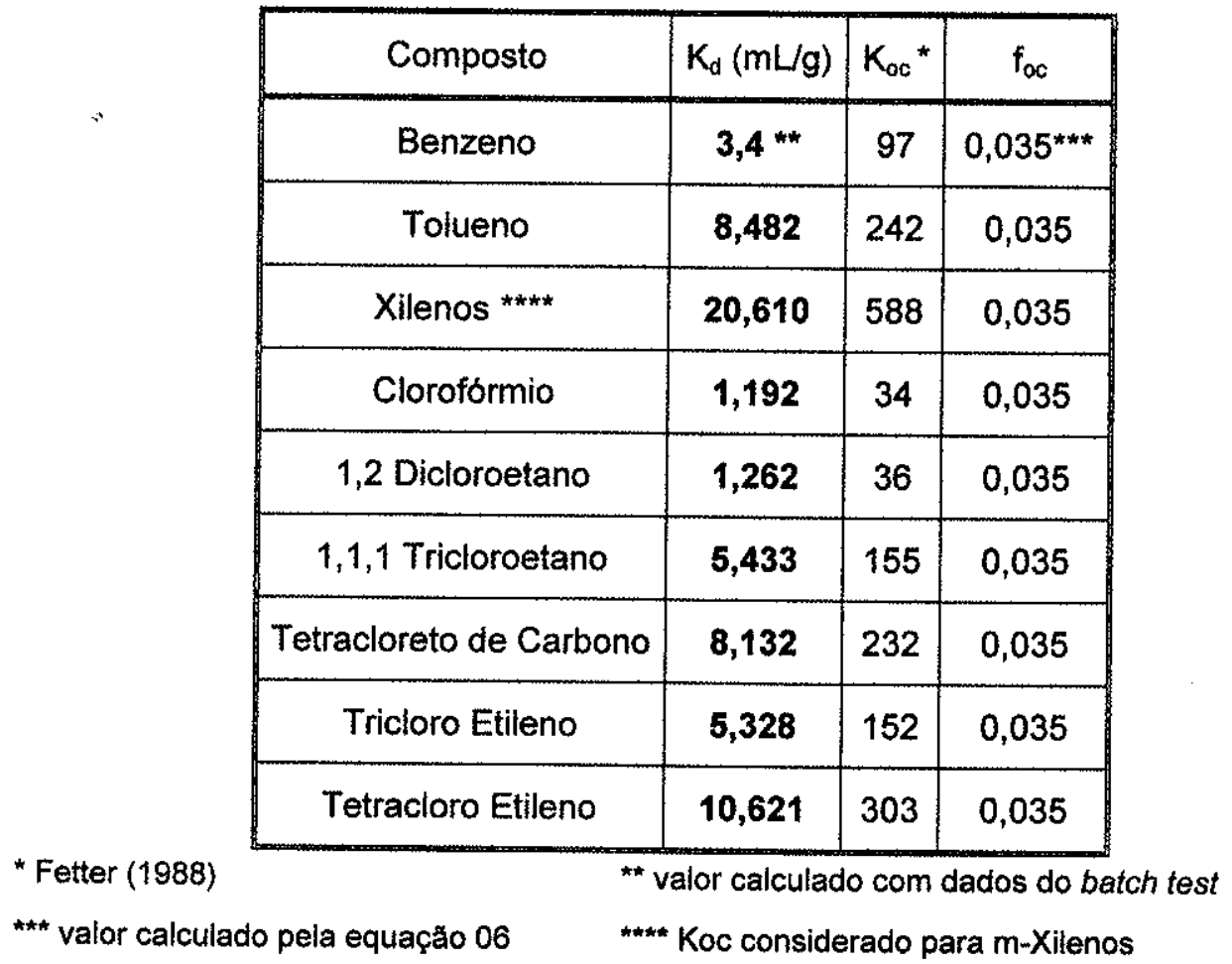

Uma vez calculados os valores de $K_{d}$, foram calculados os fatores de retardamento $\left(F_{r}\right)$, a partir da Equação 09 , conforme valores apresentados na Tabela 07. Para efeito de cálculos foram considerados os valores médios de densidade e porosidade do solo, de acordo com os dados da Tabela 01. 
Tabela 07 - Fatores de Retardamento Calculados

\begin{tabular}{|c|c|c|c|c|}
\hline Composto & $\begin{array}{c}\text { densidade do } \\
\text { solo seco } \\
\left(\mathrm{g} / \mathrm{cm}^{3}\right)\end{array}$ & $\begin{array}{c}\text { porosidade } \\
\text { total do solo }\end{array}$ & $\mathrm{K}_{\mathrm{d}}(\mathrm{mL} / \mathrm{g})$ & $\mathrm{F}_{\mathrm{r}}$ \\
\hline Benzeno & 1,37 & 0,52 & 3,4 & $\mathbf{9 , 9 6}$ \\
\hline Tolueno & 1,37 & 0,52 & 8,482 & $\mathbf{2 3 , 3 5}$ \\
\hline Xilenos & 1,37 & 0,52 & 20,610 & $\mathbf{5 5 , 3 0}$ \\
\hline Clorofórmio & 1,37 & 0,52 & 1,192 & $\mathbf{4 , 1 4}$ \\
\hline 1,2 Dicloroetano & 1,37 & 0,52 & 1,262 & $\mathbf{4 , 3 2}$ \\
\hline $1,1,1$ Tricloroetano & 1,37 & 0,52 & 5,433 & $\mathbf{1 5 , 3 1}$ \\
\hline Tetracloreto de Carbono & 1,37 & 0,52 & 8,132 & $\mathbf{2 2 , 4 2}$ \\
\hline Tricloro Etileno & 1,37 & 0,52 & 5,328 & $\mathbf{1 5 , 0 3}$ \\
\hline Tetracloro Etileno & 1,37 & 0,52 & 10,621 & $\mathbf{2 8 , 9 8}$ \\
\hline
\end{tabular}

De acordo com a Tabela 07, Clorofórmio e 1,2 Dicloroetano são os compostos de interesse que sofrem menor retardamento, indicando maior mobilidade.

\subsubsection{Velocidade de Deslocamento das Plumas de Contaminação}

Foram adotadas as velocidades médias de fluxo da água subterrânea calculadas em 7.1.7.1 para os cálculos das velocidade de deslocamento das plumas de contaminação sob influência dos fatores de retardamento, de acordo com a Equação 10.

As Tabelas $08 \mathrm{a}$ e $08 \mathrm{~b}$ apresentam os resultados finais dos cálculos efetuados, considerando as velocidades médias de fluxo da água subterrânea calculadas para os dias 13/11/1997 e 16/05/1998. 
Tabela 08 a - Velocidade de Deslocamento das Plumas de Contaminação. Velocidade Média da Água Subterrânea em 13/11/1997

\begin{tabular}{|c|c|c|c|c|c|}
\hline Composto & $\begin{array}{c}\text { Velocidade } \\
\text { Média da Agua } \\
\text { Subterrânea em } \\
13 / 11 / 97 \\
\text { (cm/dia) }\end{array}$ & $\mathrm{F}_{\mathrm{r}}$ & $\begin{array}{c}\text { Velocidade Final } \\
\text { da Pluma de } \\
\text { Contaminação } \\
\text { (cm/dia) }\end{array}$ & $\begin{array}{c}\text { Tempo } \\
\text { Estimado para o } \\
\text { Contaminante } \\
\text { Chegar a } \\
\text { Margem da } \\
\text { Represa - } \\
170,4 \mathrm{~m} \text { (dias) }\end{array}$ & $\begin{array}{c}\text { Tempo Estimado } \\
\text { para o } \\
\text { Contaminante } \\
\text { Chegar à Margem } \\
\text { da Represa - } \\
170,4 \text { m (anos) }\end{array}$ \\
\hline Benzeno & 5,67 & 9,96 & 0,57 & $29.855,51$ & 81,79 \\
\hline Tolueno & 5,67 & 23,35 & 0,24 & $70.002,99$ & 191,79 \\
\hline Xilenos & 5,67 & 55,30 & 0,10 & $165.803,20$ & 454,25 \\
\hline Clorofórmio & 5,67 & 4,14 & 1,37 & $12.412,13$ & 34,00 \\
\hline 1,2 Dicloroetano & 5,67 & 4,32 & 1,31 & $12.965,89$ & 35,52 \\
\hline $1,1,1$ Tricloroetano & 5,67 & 15,31 & 0,37 & $45.914,51$ & 125,79 \\
\hline Tetracloreto de Carbono & 5,67 & 22,42 & 0,25 & $67.234,20$ & 184,20 \\
\hline Tricloro Etileno & 5,67 & 15,03 & 0,38 & $45.083,87$ & 123,52 \\
\hline Tetracloro Etileno & 5,67 & 28,98 & 0,19 & $86.892,62$ & 238,06 \\
\hline
\end{tabular}

Tabela 08 b - Velocidade de Deslocamento das Plumas de Contaminação. Velocidade Média da Água Subterrânea em 16/05/1998

\begin{tabular}{|c|c|c|c|c|c|}
\hline Composto & $\begin{array}{c}\text { Velocidade } \\
\text { Média da Agua } \\
\text { Subterrânea em } \\
16 / 05 / 98 \\
\text { (cm/dia) }\end{array}$ & $F_{r}$ & $\begin{array}{c}\text { Velocidade Final } \\
\text { da Pluma de } \\
\text { Contaminação } \\
\text { (cm/dia) }\end{array}$ & $\begin{array}{c}\text { Tempo Estimado } \\
\text { para o } \\
\text { Contaminante } \\
\text { Chegar à Margem } \\
\text { da Represa - } \\
170,4 \text { m (dias) }\end{array}$ & $\begin{array}{c}\text { Tempo Estimado } \\
\text { para o } \\
\text { Contaminante } \\
\text { Chegar à Margem } \\
\text { da Represa - } \\
170,4 \text { m (anos) }\end{array}$ \\
\hline Benzeno & 7,4 & 9,96 & 0,74 & $22.875,78$ & 62,67 \\
\hline Tolueno & 7,4 & 23,35 & 0,32 & $53.637,43$ & 146,95 \\
\hline Xilenos & 7,4 & 55,30 & 0,13 & $127.041,10$ & 348,06 \\
\hline Clorofórmio & 7,4 & 4,14 & 1,79 & $9.510,37$ & 26,05 \\
\hline 1,2 Dicloroetano & 7,4 & 4,32 & 1,71 & $9.934,67$ & 27,22 \\
\hline $1,1,1$ Tricloroetano & 7,4 & 15,31 & 0,48 & $35.180,44$ & 96,38 \\
\hline Tetracioreto de Carbono & 7,4 & 22,42 & 0,33 & $51.515,94$ & 141,14 \\
\hline Tricloro Etileno & 7,4 & 15,03 & 0,49 & $34.543,99$ & 94,64 \\
\hline Tetracloro Etileno & 7,4 & 28,98 & 0,25 & $66.578,54$ & 182,41 \\
\hline
\end{tabular}


De acordo com os dados apresentados nas Tabelas 08 a e $08 \mathrm{~b}$, o trajeto entre a fábrica de tintas da indústria e a margem da represa, que perfaz uma distância aproximada de $170,4 \mathrm{~m}$, deve ser percorrido em menos tempo pelo Clorofórmio, seguido de 1,2 Dicloroetano e em maior tempo pelos Xilenos (considerando os coeficientes de partição para m-xilenos). 


\section{Discussão dos Resultados}

Os mapas potenciométricos apresentados nas Figuras 11 a e $11 \mathrm{~b}$ possuem evidente semelhança com a superfície topográfica do terreno representada nas Figuras 09,10 a e $10 \mathrm{~b}$. Por este motivo, os slug tests realizados nos PMs 08,14 e 24, distribuídos nas proximidades de taludes, na porção central da empresa, apresentam elevados valores de condutividade hidráulica, culminando em elevados valores para a velocidade linear da água subterrânea no local.

Os valores extremos de velocidade da água subterrânea não foram considerados para efeito de cálculos de transporte, uma vez que refletem situações locais e podem ocasionar super ou subestimativa dos tempos de deslocamento das plumas de contaminação.

A partir das áreas fontes de contaminação A e B, o sentido preferencial de fluxo da água subterrânea possui orientação N-S e, secundariamente, NW-SE. A migração as plumas obedece, de forma geral, o sentido de fluxo da água subterrânea, havendo poucas variações no sentido de migração, sendo mais expressivas nas plumas de contaminação delimitadas para os compostos organoclorados, Figuras 15 a, 20 b e 20 c, 21 b e 21 c.

Os tambores instalados na zona que margeia a represa forneceram valores de fluxo coerentes e menores que os valores determinados para a velocidade linear da água subterrânea devido à maior presença de material argiloso.

Ainda com relação aos tambores, as análises químicas, que indicaram ausência de contaminação, permitiram delimitar as plumas a jusante da área e concluir sobre a inexistência de aporte de contaminantes em concentrações superiores a $5 \mu \mathrm{g} / \mathrm{L}$ (limite de detecção do aparelho utilizado nas análises), no período das análises, na zona que margeia a represa.

Após instalado, os tambores mantêm em seu interior volume d'água. Assim sendo, deve-se ressaltar que uma das explicações para a não deteç̧ão de contaminantes em amostras de água coletadas do experimento poderia ser a diluição do contaminante na água aprisionada no interior do tambor. 
Os cálculos de velocidade de deslocamento das plumas de contaminação indicaram, no entanto, que o Clorofórmio, contaminante que apresenta maior velocidade calculada, deve percorrer o trajeto desde a fonte (fábrica de tintas) até a margem da represa em, no mínimo, 26,05 anos. Considerando corretas as estimativas referentes à época em que se deu o acidente gerador da contaminação (20 anos atrás) e à velocidade de deslocamento das plumas, pode-se inferir que os contaminantes avaliados ainda não chegaram a atingir à zona marginal da represa de Guarapiranga.

As plumas demarcadas para 1,2 Dicloroetano (Figuras $15 \mathrm{a}, 15 \mathrm{~b} \mathrm{e} 15 \mathrm{c}$ ) indicam a proximidade da frente de contaminação à zona que margeia a represa. Contudo, eventuais concentrações que possam ter chegado a atingir os limites da represa estão abaixo dos limites de detecção das análises, uma vez que não foram identificadas pela amostragem dos tambores.

Os fatores de retardamento obtidos para os contaminantes avaliados encontram-se acima dos valores médios apresentados na literatura internacional consultada. Os valores da literatura internacional são considerados, no entanto, para parâmetros referentes ao hemisfério norte, onde as condições climáticas propiciam a formação de solos com menores porcentagens de matéria orgânica.

No Brasil e evidentemente na área de estudos, a maior porcentagem de matéria orgânica encontrada no solo formado em clima tropical pode ser responsável pelos elevados fatores de retardamento determinados para os contaminantes avaliados.

A amostragem de solo para realização do Batch Test, no entanto, se deu em profundidade máxima de 1,07 m, conforme apresentado na Tabela 01; eventualmente, a amostragem de solo em profundidades maiores poderia indicar a presença de menor porcentagem de matéria orgânica, resultando em menores fatores de retardamento. Ainda assim, a precisa determinação do retardamento imposto a cada contaminante no caso avaliado poderia ser feita apenas com o acompanhamento de transporte dos contaminantes associados à traçadores adicionados à água subterrânea.

A montante, a ausência de PMs entre as áreas fontes de contaminação $A$ e $B$ e entre a área fonte $A$ e a zona que margeia a represa (no sentido de fluxo $\mathrm{N}-\mathrm{S}$ ) dificultaram a demarcação das pluma de contaminação. 
Propositalmente, as plumas de Tolueno (Figuras $13 \mathrm{a}, 13 \mathrm{~b}$ e $13 \mathrm{c}$ ) possuíram interpretação cartográfica diferenciada dos demais compostos orgânicos derivados de hidrocarbonetos. As plumas de Benzeno (Figuras $12 \mathrm{a}, 12 \mathrm{be} 12 \mathrm{c}$ ) e Xilenos (Figuras $14 \mathrm{a}, 14 \mathrm{~b}$ e $14 \mathrm{c}$ ), na zona intermediária entre as áreas fontes $\mathrm{A}$ e $\mathrm{B}$ foram interligadas; inferindo-se a continuidade de contaminação. Contudo, a interpretação evolutiva das fases de contaminação permaneceu a mesma para os três compostos, indicando apenas uma menor área contaminada para Tolueno.

Para efeito de simulações de transporte de contaminantes, as diferentes interpretações cartográficas para as plumas de BTX não ocasionam problemas, uma vez que são determinadas as frentes de contaminação nos sentidos preferenciais de fluxo, havendo diferenças no interior das plumas.

No entanto, a demarcação diferenciada das plumas de contaminação de BTX deve ser discretizada em seu interior, através da instalação de novos PMs, para efeito de estimativa de volume de contaminantes e área contaminada, essenciais à adoção de sistemas de recuperação. 


\section{Conclusões}

A partir dos trabalhos realizados, concluímos:

- Três fontes de contaminação foram identificadas na área, fontes estas possivelmente não controladas devido ao aumento de concentrações indicado no último monitoramento de 16 de maio de 1998;

- os tambores instalados na zona que margeia a represa forneceram dados coerentes de fluxo da água subterrânea e indicaram ausência de aporte de contaminantes nesta zona da represa;

- análises de amostras de água coletadas dos tambores não indicaram contaminação, permitindo-se concluir que os contaminantes ainda não chegaram ao local;

- o clorofórmio apresentou maior velocidade de deslocamento entre os contaminantes avaliados, necessitando de no mínimo 26,05 anos para atingir, a partir da área fonte de contaminação, a faixa marginal da represa de Guarapiranga. Ocorrido 0 acidente há cerca de 20 anos e medidas as concentrações, determinou-se que os contaminantes ainda não chegaram a atingir a faixa citada;

- a ausência de PMs entre as fontes de contaminação A e B e entre a fonte $A$ e a zona que margeia a represa (no sentido preferencial de fluxo $\mathrm{N}-\mathrm{S}$ ) dificultou a interpolação dos dados para demarcação das plumas;

- dentre as plumas de contaminação delimitadas, a de 1,2 Dicloroetano apresentou maior extensão em decorrência de sua persistência em relação aos processos de biodegradação e volatilização e ao baixo $F_{r}$ obtido através de seu $K_{d}$;

- os valores de $F_{r}$ obtidos são superiores aos valores encontrados na literatura para todos os contaminantes avaliados. 
- os dados citados na literatura internacional consideram parâmetros referentes ao hemisfério norte, onde os solos costumam ter menor porcentagem de matéria orgânica $e$, consequentemente, impõem menor retardamento à velocidade de transporte de contaminantes;

- a amostragem de solo para realização de Batch Test foi realizada à profundidade máxima de $1,07 \mathrm{~m}$; amostragens em profundidades maiores poderiam indicar menores concentrações de matéria orgânica (menor $f_{o c}$ ) e, portanto, menores fatores de retardamento;

- a precisa determinação do retardamento imposto a cada contaminante no caso avaliado poderia ser feita apenas com o acompanhamento de transporte dos contaminantes associados à traçadores adicionados à água subterrânea. 


\section{Recomendações}

- eliminação das fontes de contaminação através da impermeabilização das áreas da empresa em que ainda estejam sendo armazenados tambores, de forma a evitar novos derramamentos acidentais e aporte de contaminantes ao solo e água subterrânea;

- o monitoramento dos poços instalados na área de estudos, de forma a permitir o contínuo acompanhamento da evolução das plumas de contaminação identificadas em subsuperfície;

- a instalação de novas baterias de tambores na zona que margeia a represa, com coleta de amostras de água, de forma a garantir o controle da contaminação neste ponto de amostragem;

- a instalação de novos PMs entre as áreas fontes de contaminação A e B e entre a fonte $A$ e a zona que margeia a represa, na direção preferencial de fluxo N-S;

- caracterização da atenuação natural dos compostos presentes nas plumas;

- adição de traçador não reativo à água subterrânea para determinação da real velocidade de fluxo, em distâncias que permitam o acompanhamento em um ciclo hidrológico. 


\section{Referências Bibliográficas}

ABNT (1997) NBR 13895 Construção de Poços de Monitoramento.

BARKER, J.F., SUDICKY, E.A., MAYFIELD, C.I., and GILLHAM, R.W. (1989) The Fate and Persistence of Aromatic Hydrocarbons Dissolved in Groundwater: Results of Controlled Field Experiments. Presented at AAPG/SEPM/SEG/SPWLA Pacific Section Meeting, Palm Spring, California, May 10-13, 1989, Submitted to AAPG Symposium Volume-Environmental Concerns in the Petroleum Industry (ed.S.M.)

CCME - CANADIAN COUNCIL OF MINISTERS OF THE ENVIRONMENT (1994) Subsurface Assessment Handbook for Contaminated Sites. The National Contaminated Sites Remediation Program. 293 p.

CLEARY, R. W. et (1989) - Hidrologia de Águas Subterrâneas. Engenharia Hidrológica, Capítulo 04. pp 293-403. Coleção ABRH de Recursos Hídricos.

FETTER, C.W. (1988) Applied Hydrogeology. Merrill Publishing Company, Columbus, Ohio. $592 \mathrm{p}$.

FREEZE, R.A. \& CHERRY, J.A. (1979) Groundwater. Prentice Hall, Inc. New Jersey. $604 \mathrm{p}$.

HARTE et al. (1991) Toxics A to Z. A Guide to Everyday Pollution Hazards. University of California Press. Berkeley and Los Angeles, California. $479 \mathrm{p}$.

HVORSLEV, M.J., (1951) Time Lag and Soil Permeability in Groundwater Observations. U. S. Army Corps Engrs. Waterways Exp. Sta. Bull. 36, Vicksburg, Miss.

IPT - INSTITUTO DE PESQUISAS TECNOLÓGICAS DO ESTADO DE SÃO PAULO (1995) Análises Físicas em Amostras de Solos com Estruturas Deformada e Indeformada. Relatório $n^{\circ} 32896$.

IPT - INSTITUTO DE PESQUISAS TECNOLOGICAS DO ESTADO DE SÃO PAULO (1981) Mapa Geológico do Estado de São Paulo. Escala 1:500.000. 
KOLESNIKOVAS, C. (1997) Caracterização dos Riscos Representados por Armazenamento e Manuseio de Combustiveis Sobre as Linhas do Metrô em São Paulo-SP. Dissertação de Mestrado. Instituto de Geociências da Universidade de São Paulo. 89 p. São Paulo.

KUEPER, B.H., McWHORTER, D.B., and FRIND, E.O. (1989) The behaviour of dense nonaqueous phase liquid contaminants in heterogeneous porous media. Proceedings International Symposium on Contaminant Transport in Groundwater, Stuttgart, Germany, April 1989, pp.317-325.

LEE, D.R. \& CHERRY, J.A. (1978) A Field Exercise on Groundwater Flow Using Seepage Meters and Mini-Piezometers. Journal of Geological Education, v.27. p.06-10.

OLIVEIRA, E. de (1992) Contaminação de Aqüiferos por Hidrocarbonetos Provenientes de Vazamentos de Tanques de Armazenamento Subterrâneo. Dissertação de Mestrado. Instituto de Geociências da Universidade de São Paulo. São Paulo. $112 \mathrm{p}$.

OLIVEIRA, E. de (1997) Ethanol Flushing of Gasoline Residuals - Microscale and Field Scale Experiments. Tese de Doutoramento. Universidade de Waterloo. 291p.

OLIVEIRA, E. de (1998) Descontaminação de Aquiferos. Coluna de Hidrogeologia Ambiental. ABAS Informa - Boletim Informativo, $n^{\circ} 82$. Setembro de 1998.

PANKOW, J.F. \& CHERRY, J.A. (1996) Dense Chlorinated Solvents ans Others DNAPLs in Groundwater. Waterloo Press. Canada, 522p.

SALLES, F.A.F.; DUARTE, U. \& ISHIMINE, V. (1998) Aplicação de Seepage Para Determinação do Aporte Freático em Trecho Marginal da Represa de Guarapiranga. X Congresso Brasileiro de Águas Subterrâneas, São Paulo, SP.

SCHWARZENBACH, R.P. and Westall, J. (1981) Transport of Nonpolar Organic Compounds from Surface Water to Groundwater. Laboratory Sorption Studies. Environ. Sci. Technol. 15, 1360-1367.

SOUZA, H.B. de (1977) Guia Técnico de Coleta de Amostras. Companhia de Tecnologia e Saneamento Ambiental (CETESB), 257p. il. 
TERZAGHI 1940 An Experimental Investigation of Protective Filters. Soil Mechanics Serie $n^{\circ} 07$, January, Harvard University,

UNITED STATES ENVIRONMENTAL PROTECTION AGENCY (USEPA) (1985). Water Quality Assessment: A Screening Procedure for Toxic and Conventional Pollutants in Surface an Groundwater - Parts I and II (revised 1985). Athens. GA. Environmental Research Lab. 


\section{APÊNDICE 01}

Perfis Construtivos dos Poços de Monitoramento 


\title{
Legenda Geral dos Perfis Construtivos dos Poços de Monitoramento
}

\author{
Descrição Litológica
}

Argila e argila com areia fina

Argila arenosa

Areia fina a média

Areia grossa com fragmentos de rocha

\section{Aspectos Construtivos}

Bentonita

Solo cimento

$\therefore \quad$ Pré filtro

Filtro

Água Subterrânea 

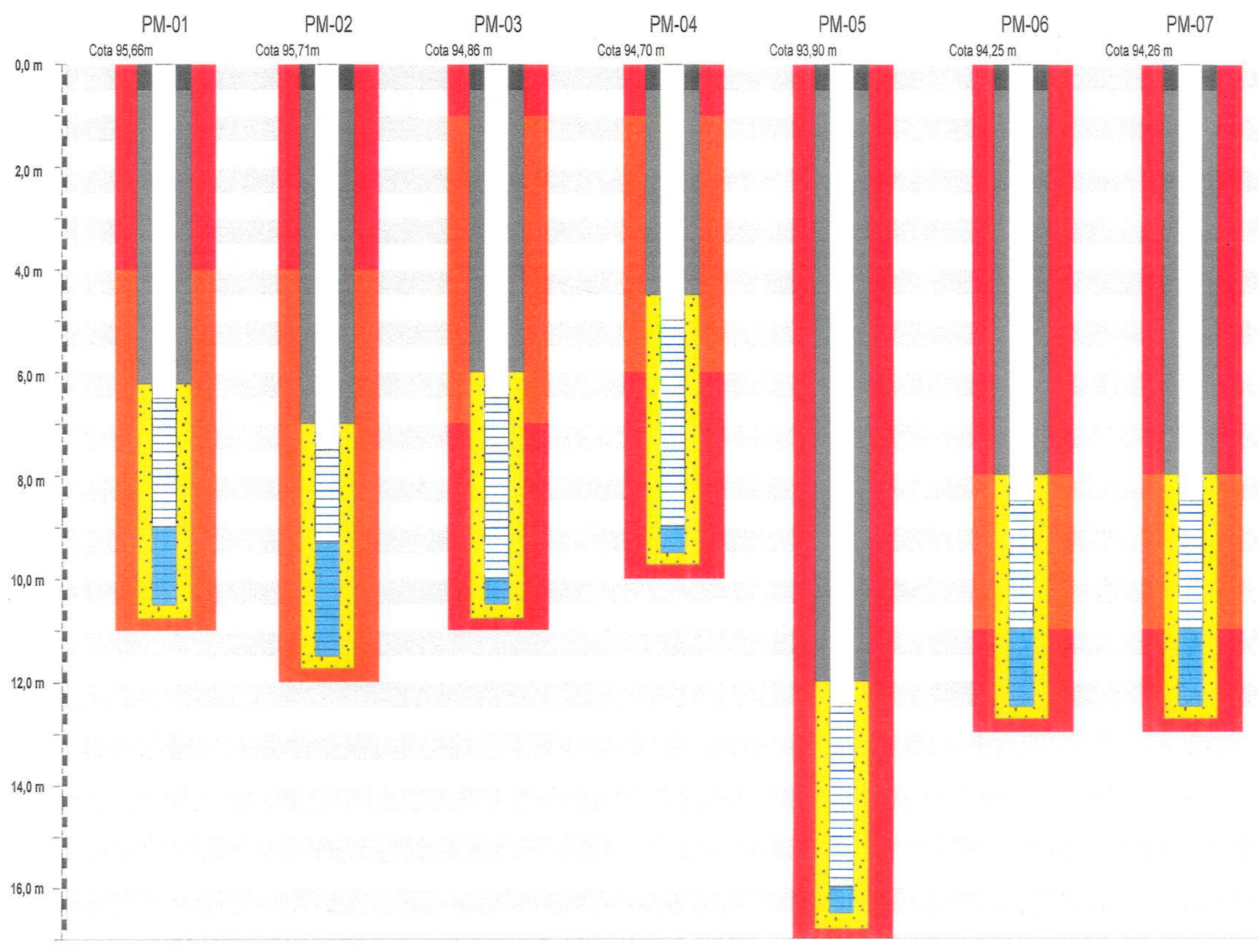

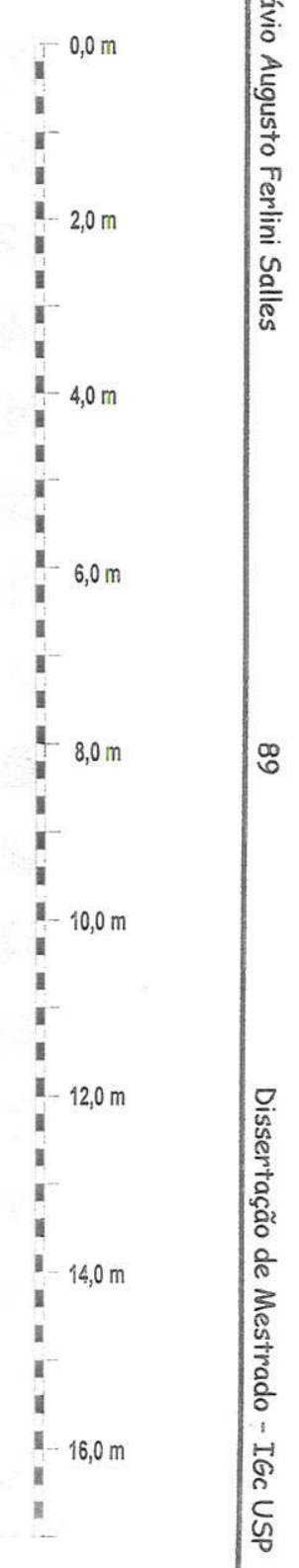




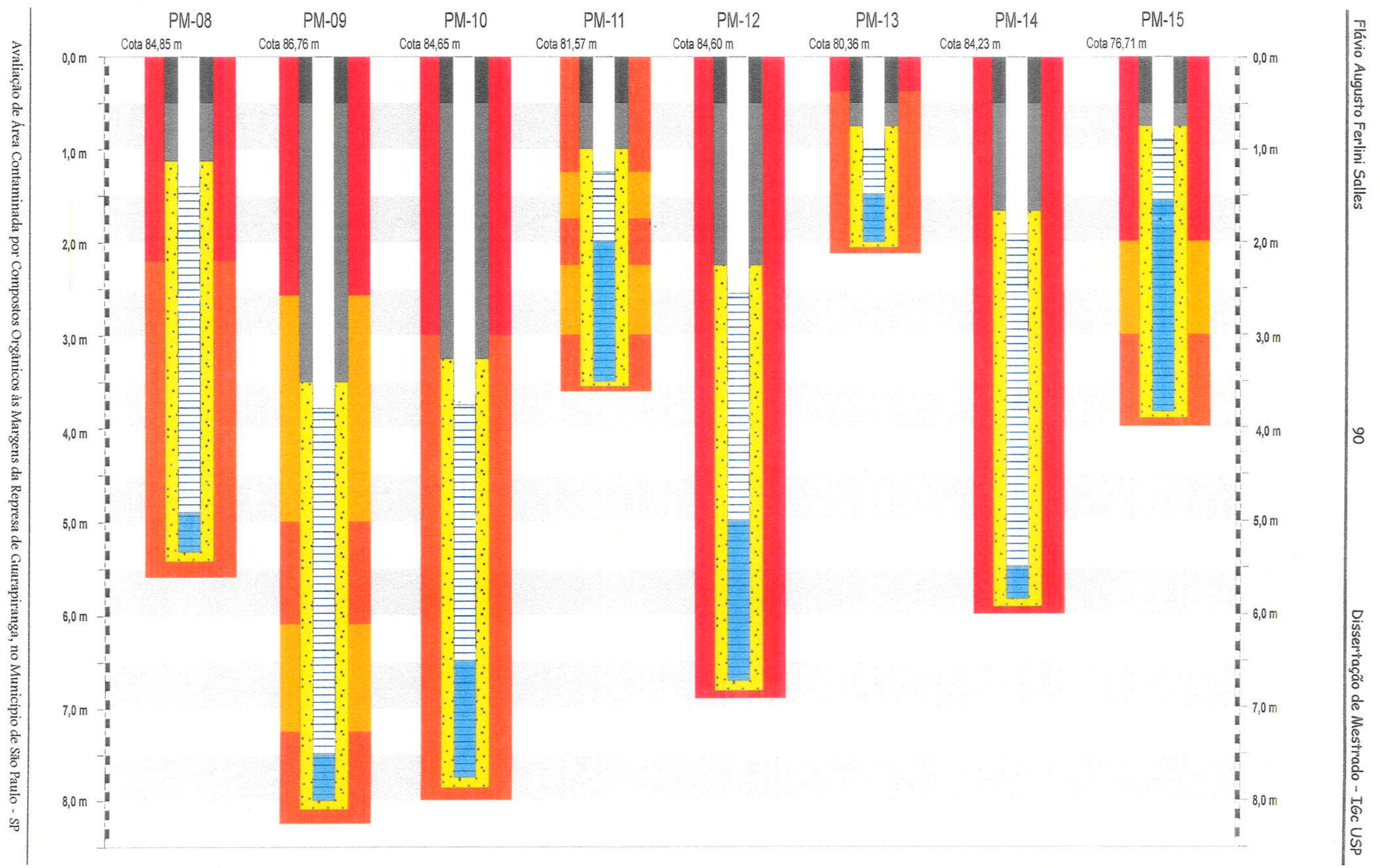




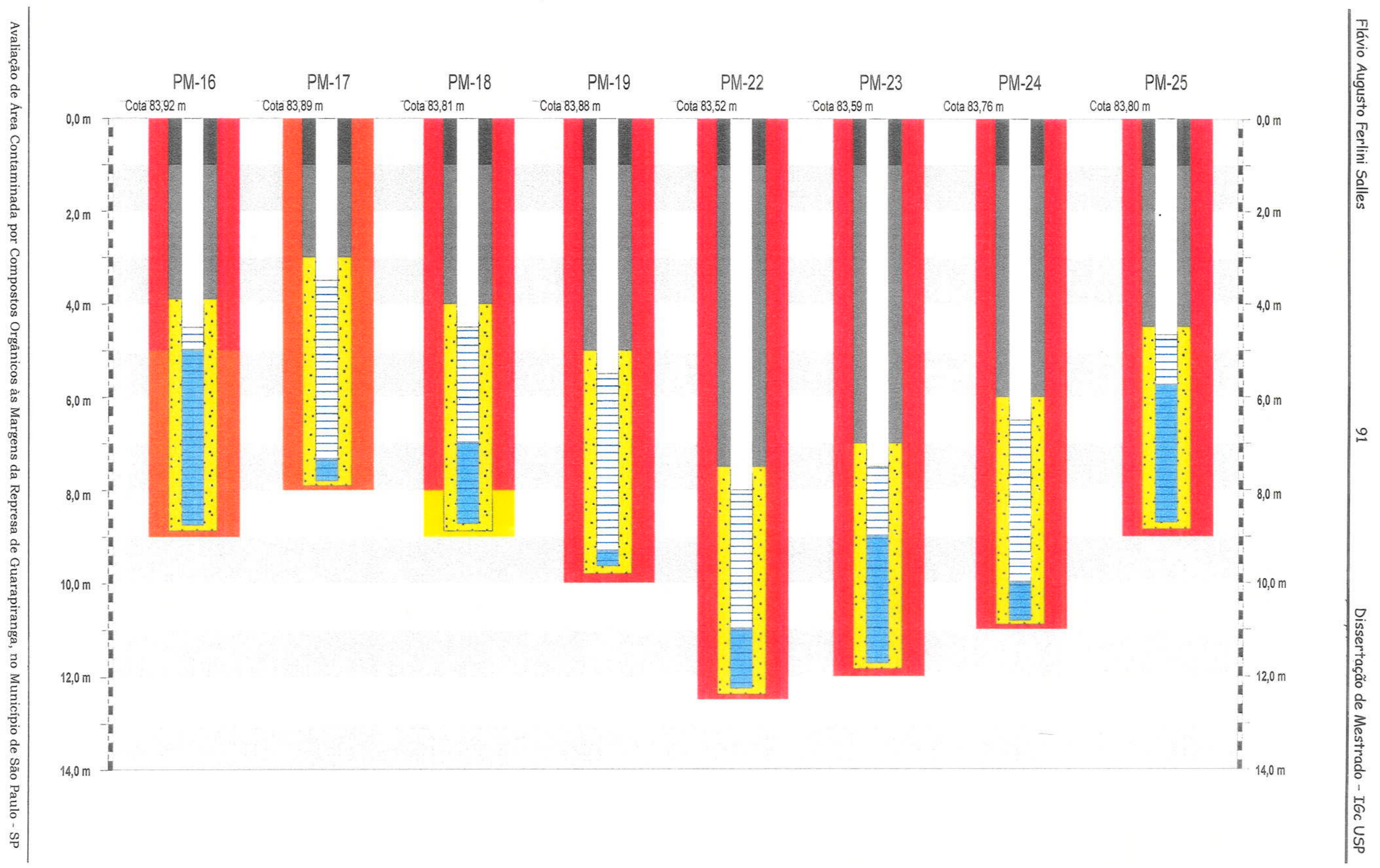




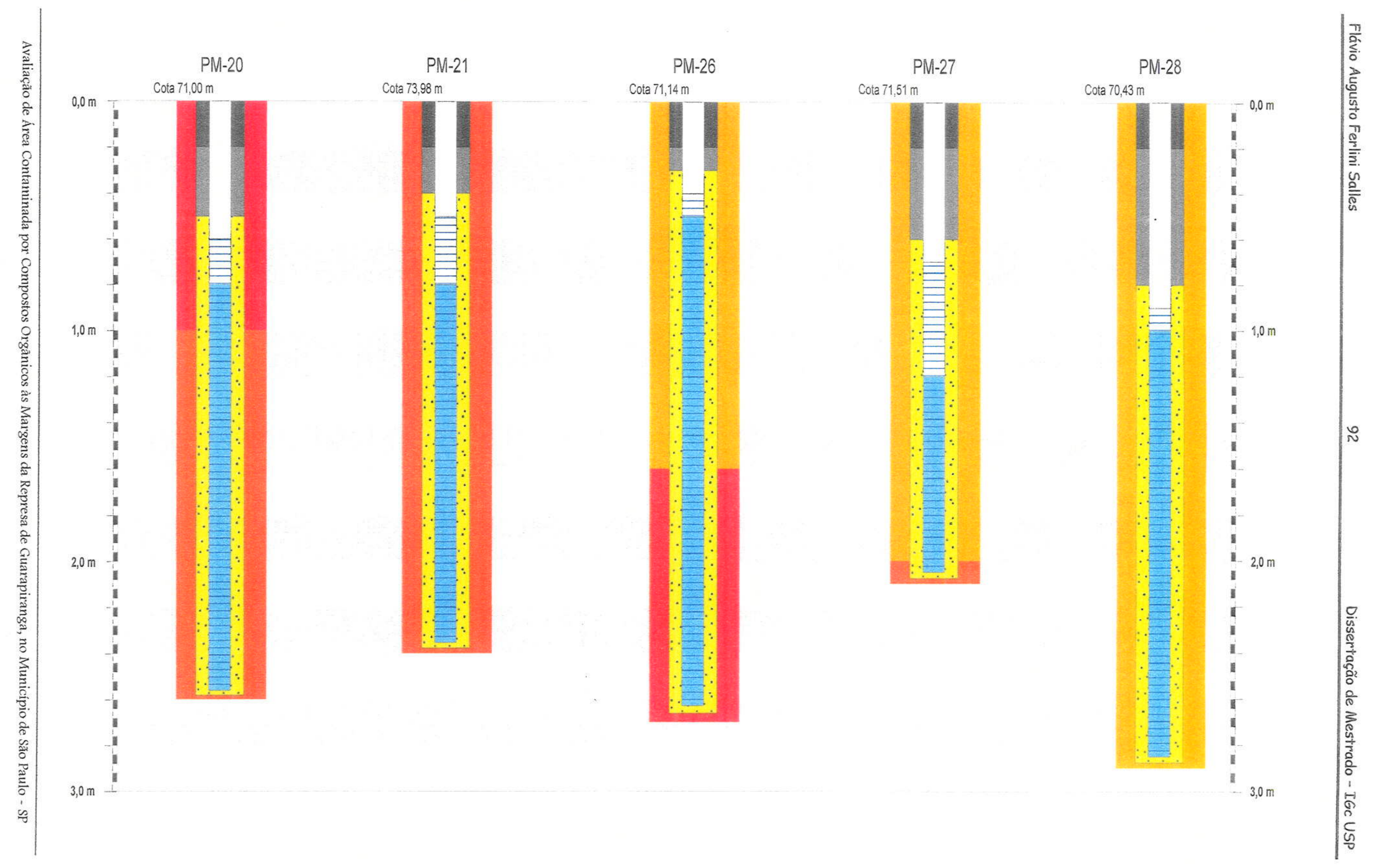




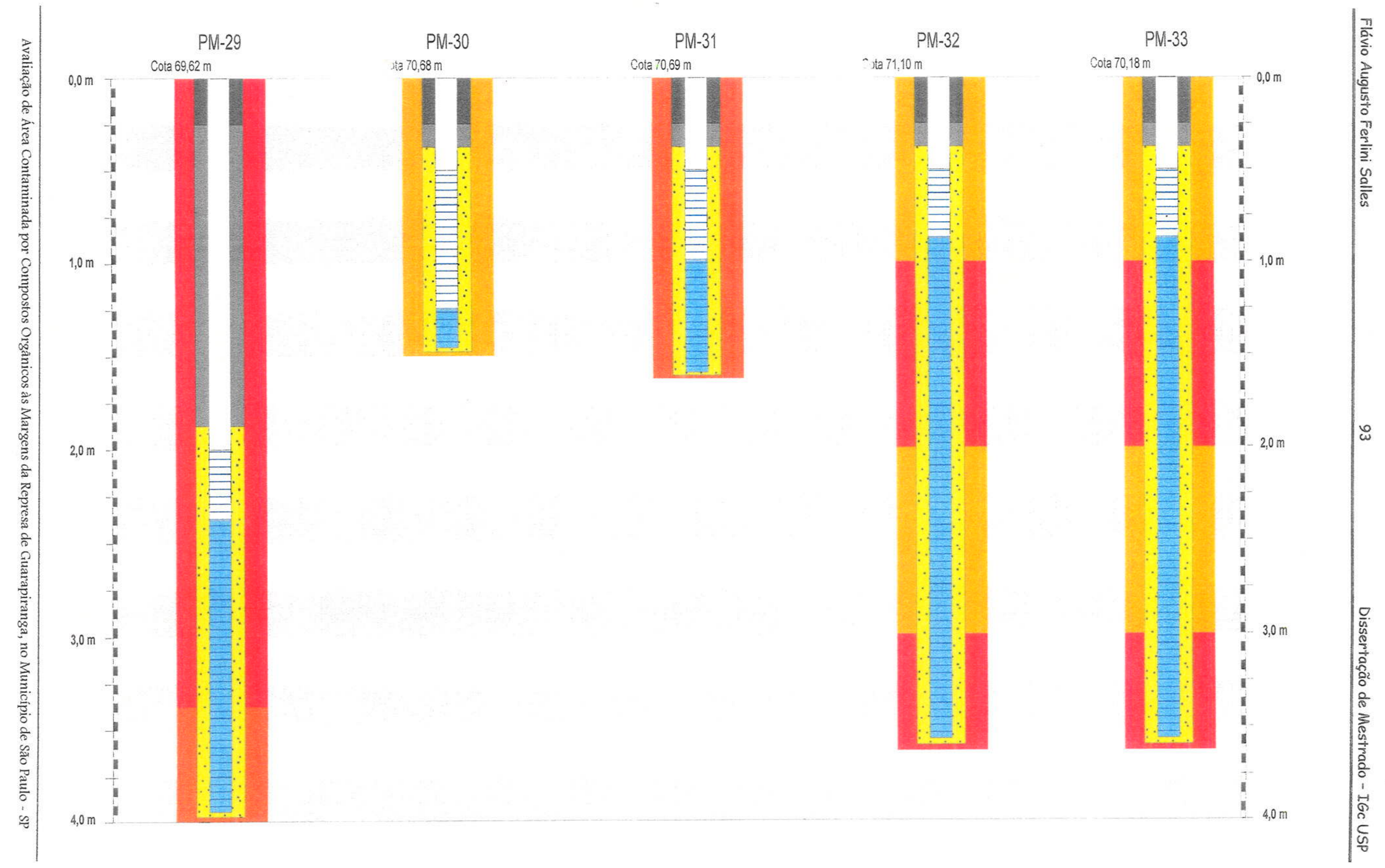




\title{
APÊNDICE 02
}

\author{
Medidas de Nível D'Água e \\ Determinação da Potenciometria Local
}




\section{Niveis D'água e Potenciometria nas Duas Datas de Monitoramento}

\begin{tabular}{|c|c|c|c|c|c|}
\hline Poço & \begin{tabular}{|c|} 
Cota \\
$(\mathrm{m})$
\end{tabular} & \begin{tabular}{|c|} 
Nivel D'Água (m) \\
$13 / 11 / 97$ \\
\end{tabular} & $\begin{array}{c}\text { Potenciometria }(\mathrm{m}) \\
13 / 11 / 97 \\
\end{array}$ & $\begin{array}{c}\text { Nível D'Água (m) } \\
16 / 05 / 98 \\
\end{array}$ & $\begin{array}{c}\text { Potenciometria (m) } \\
16 / 05 / 98 \\
\end{array}$ \\
\hline 1 & 95,66 & 8,77 & 86,89 & 8,13 & 87,53 \\
\hline 2 & 95,71 & 8,91 & 86,80 & 8,47 & 87,24 \\
\hline 3 & 94,86 & 8,30 & 86,56 & 8,98 & 85,88 \\
\hline 4 & 94,70 & 8,45 & 86,25 & 9,87 & 84,83 \\
\hline 5 & 93,90 & 13,32 & 80,58 & 12,45 & 81,45 \\
\hline 6 & 94,25 & 8,10 & 86,15 & NA & NA \\
\hline 7 & 94,26 & 8,25 & 86,01 & 10,89 & 83,37 \\
\hline 8 & 84,85 & 4,40 & 80,45 & 4,27 & 80,58 \\
\hline 9 & 86,76 & 7,52 & 79,24 & 7,25 & 79,51 \\
\hline 10 & 84,65 & NA & NA & NA & NA \\
\hline 11 & 81,57 & 1,74 & 79,83 & 1,51 & 80,07 \\
\hline 12 & 84,60 & 4,30 & 80,30 & NA & NA \\
\hline 13 & 80,36 & 1,38 & 78,98 & 1,22 & 79,14 \\
\hline 14 & 84,23 & 4,52 & 79,71 & 3,99 & 80,24 \\
\hline 15 & 76,77 & 1,30 & 75,47 & 1,15 & 75,62 \\
\hline 16 & 83,92 & 4,80 & 79,12 & 5,26 & 78,67 \\
\hline 17 & 83,89 & 4,73 & 79,16 & 4,54 & 79,36 \\
\hline 18 & 83,81 & 6,58 & 77,23 & 6,27 & 77,54 \\
\hline 19 & 83,88 & 7,00 & 76,88 & 6,76 & 77,13 \\
\hline 20 & 71,00 & 0,74 & 70,26 & NA & NA \\
\hline 21 & 73,98 & 0,70 & 73,28 & NA & NA \\
\hline 22 & 83,52 & 9,53 & 73,99 & 9,18 & 74,34 \\
\hline 23 & 83,59 & 9,46 & 74,13 & 8,72 & 74,88 \\
\hline 24 & 83,76 & 9,39 & 74,37 & NA & NA \\
\hline 25 & 83,80 & 9,40 & 74,40 & NA & NA \\
\hline 26 & 71,14 & 0,43 & 70,71 & NA & NA \\
\hline 27 & 71,51 & 0,50 & 71,01 & 0,92 & 70,59 \\
\hline 28 & 70,43 & 0,30 & 70,13 & 0,87 & 69,56 \\
\hline 29 & 69,62 & 0,40 & 69,22 & NA & NA \\
\hline 30 & 70,68 & 0,44 & 70,24 & 1,16 & 69,52 \\
\hline 31 & 70,69 & 0,37 & 70,32 & 0,73 & 69,96 \\
\hline 32 & 71,10 & 0,35 & 70,75 & 0,69 & 70,41 \\
\hline 33 & 70,18 & 0,20 & 69,98 & 0,00 & 70,18 \\
\hline
\end{tabular}

N - Näo Amostrado 


\section{APÊNDICE 03}

\section{Velocidades Calculadas da Água Subterrânea}


Velocidades da Água Subterrânea. Gradientes Hidráulicos em 13/11/1997

\begin{tabular}{|c|c|c|}
\hline PM Avaliado & $\begin{array}{c}\text { Velocidade da Água } \\
\text { Subterrânea (cm/dia) } \\
\text { para gradiente igual a 7,5 \% }\end{array}$ & $\begin{array}{c}\text { Velocidade da Água } \\
\text { Subterrânea (cm/dia) } \\
\text { para gradiente igual a 14,7\% }\end{array}$ \\
\hline PM-07 & 5,13 & 10,06 \\
\hline PM-08 & 7,58 & 14,86 \\
\hline PM-12 & 0,30 & 0,58 \\
\hline PM-14 & 7,97 & 15,62 \\
\hline PM-16 & 1,13 & 2,21 \\
\hline PM-17 & 2,27 & 4,45 \\
\hline PM-18 & 3,25 & 6,38 \\
\hline PM-19 & 3,29 & 6,44 \\
\hline PM-22 & 2,87 & 5,63 \\
\hline PM-23 & 1,80 & 3,53 \\
\hline PM-24 & 6,54 & 12,83 \\
\hline
\end{tabular}

Velocidades da Água Subterrânea. Gradientes Hidráulicos em 16/05/1998.

\begin{tabular}{|c|c|c|}
\hline PM Avaliado & $\begin{array}{c}\text { Velocidade da Água } \\
\text { Subterrânea (cm/dia) } \\
\text { para gradiente igual a 13,6 \% }\end{array}$ & $\begin{array}{c}\text { Velocidade da Água } \\
\text { Subterrânea (cm/dia) } \\
\text { para gradiente igual a 15,4 \% }\end{array}$ \\
\hline PM-07 & 9,31 & 10,54 \\
\hline PM-08 & 13,75 & 15,57 \\
\hline PM-12 & 0,54 & 0,61 \\
\hline PM-14 & 14,45 & 16,37 \\
\hline PM-16 & 2,04 & 2,32 \\
\hline PM-17 & 4,11 & 4,66 \\
\hline PM-18 & 5,90 & 6,68 \\
\hline PM-19 & 5,96 & 6,75 \\
\hline PM-22 & 5,21 & 5,89 \\
\hline PM-23 & 3,27 & 3,70 \\
\hline PM-24 & 11,87 & 13,44 \\
\hline
\end{tabular}




\section{APÊNDICE 04}

\section{Análises Químicas para Determinação de Benzeno, Tolueno e Xilenos em Amostras dos PMs}


Resultados das Análises (PMs)

Concentrações de Benzeno (B), Tolueno $(T)$ e Xilenos $(X)$ em $\mu \mathrm{g} / \mathrm{L}$.

\begin{tabular}{|c|c|c|c|c|c|c|c|c|c|}
\hline \multirow{3}{*}{$\begin{array}{c}\text { Poço } \\
01\end{array}$} & \multicolumn{3}{|c|}{$21 / 03 / 97$} & \multicolumn{3}{|c|}{$10 / 12 / 97$} & \multicolumn{3}{|c|}{$16 / 05 / 98$} \\
\hline & $B$ & $\mathbf{T}$ & $x$ & B & $T$ & $x$ & B & $T$ & $x$ \\
\hline & 80,0 & 452,5 & 525,0 & 182,1 & 383,9 & $3,156,0$ & 146,5 & $2.295,4$ & $10.417,4$ \\
\hline 02 & 240,0 & 706,0 & $3,475,0$ & 28,8 & ND & 173,4 & 323,0 & $4.220,2$ & $14.780,7$ \\
\hline 03 & ND & ND & ND & ND & ND & ND & ND & ND & ND \\
\hline 04 & ND & ND & ND & ND & ND & ND & ND & 14,4 & 10,0 \\
\hline 05 & ND & ND & ND & ND & ND & ND & ND & ND & ND \\
\hline 06 & $\mathrm{~N}$ & $\mathrm{~N}$ & $N$ & 132,9 & 997,1 & 412,6 & $N$ & $N$ & $N$ \\
\hline 07 & 162,5 & $1.350,0$ & 824,7 & 146,5 & $1.052,2$ & 454,9 & 244,5 & $4.630,4$ & $2.743,8$ \\
\hline 08 & $N$ & $\mathrm{~N}$ & $N$ & 318,6 & $8.232,9$ & $5.079,6$ & 479,1 & $9.923,3$ & $9.544,2$ \\
\hline 09 & ND & ND & ND & ND & ND & ND & ND & ND & ND \\
\hline 10 & ND & 50,0 & ND & $N$ & $N$ & $\mathrm{~N}$ & $\mathrm{~N}$ & $\mathrm{~N}$ & $N$ \\
\hline 11 & ND & ND & ND & ND & ND & ND & ND & 2,8 & ND \\
\hline 12 & 200,0 & $7.242,0$ & $1.650,0$ & ND & ND & ND & $\mathrm{N}$ & $\mathrm{N}$ & $\mathrm{N}$ \\
\hline 13 & 5,0 & ND & ND & ND & ND & 20,8 & 6,8 & 2,3 & ND \\
\hline 14 & ND & 265,0 & 70,0 & 3,2 & ND & ND & ND & ND & ND \\
\hline 15 & ND & ND & ND & 11,1 & ND & ND & ND & 7,1 & ND \\
\hline 16 & ND & 55,0 & ND & ND & ND & ND & ND & 6,3 & ND \\
\hline 17 & ND & 55,0 & ND & ND & ND & ND & ND & ND & ND \\
\hline 18 & ND & 50,0 & ND & 3,7 & ND & ND & ND & ND & ND \\
\hline 19 & ND & 82,5 & ND & 5,5 & ND & ND & ND & ND & ND \\
\hline 20 & $\mathrm{~N}$ & $N$ & $\mathrm{~N}$ & 31,4 & ND & ND & $N$ & $\mathrm{~N}$ & $\mathrm{~N}$ \\
\hline 21 & ND & ND & ND & ND & ND & 78,3 & $N$ & $\mathrm{~N}$ & $N$ \\
\hline 22 & ND & 60,0 & ND & ND & ND & ND & ND & ND & ND \\
\hline 23 & ND & 50,0 & ND & ND & ND & ND & ND & ND & ND \\
\hline 24 & ND & 82,5 & ND & $\mathrm{N}$ & $N$ & $\mathrm{~N}$ & $\mathrm{~N}$ & $\mathrm{~N}$ & $N$ \\
\hline 25 & $N$ & $N$ & $N$ & 0 & 0 & 0 & $\mathrm{~N}$ & $\mathrm{~N}$ & $\mathrm{~N}$ \\
\hline 26 & ND & ND & ND & ND & ND & 125,5 & $\mathrm{~N}$ & $N$ & $\mathrm{~N}$ \\
\hline 27 & 5,0 & ND & ND & ND & ND & ND & ND & 7,3 & ND \\
\hline 28 & ND & ND & ND & 18,3 & ND & 2,7 & 2,1 & 7,5 & 3,8 \\
\hline 29 & $N$ & $N$ & $\mathrm{~N}$ & ND & ND & ND & $N$ & $N$ & $\mathrm{~N}$ \\
\hline 30 & ND & ND & ND & ND & ND & ND & ND & 5,5 & ND \\
\hline 31 & 322,5 & $4.650,0$ & 700,0 & ND & ND & ND & ND & 12,9 & ND \\
\hline 32 & ND & ND & ND & ND & ND & ND & ND & 5,2 & ND \\
\hline 33 & ND & ND & ND & 2,6 & ND & ND & 5,6 & 1,5 & ND \\
\hline
\end{tabular}




\section{APÊNDICE 05}

\section{Análises Químicas para Determinação de Compostos Organoclorados em Amostras dos PMs}


Resultados das Análises. Concentrações de Organoclorados em $\mu \mathrm{g} / \mathrm{L}$

Primeiro Evento de Amostragem.

\begin{tabular}{|c|c|c|c|c|c|c|}
\hline \multirow[b]{2}{*}{ Amostra } & \multicolumn{6}{|c|}{21 de março de 1997} \\
\hline & Clorofórmio & $\begin{array}{c}1,2- \\
\text { Dicloro } \\
\text { Etano }\end{array}$ & $\begin{array}{c}1,1,1- \\
\text { Tricloro- } \\
\text { Etano } \\
\end{array}$ & $\begin{array}{c}\text { Tetracloreto de } \\
\text { Carbono }\end{array}$ & $\begin{array}{l}\text { Tricloro - } \\
\text { Etileno }\end{array}$ & $\begin{array}{c}\text { Tetracloro - } \\
\text { Etileno }\end{array}$ \\
\hline PM-01 & 28,75 & 73,57 & ND & ND & 3,72 & 0,47 \\
\hline PM-02 & ND & 4,25 & ND & ND & 0,14 & ND \\
\hline PM-03 & 29,75 & ND & 18,25 & ND & 12,00 & 9,25 \\
\hline PM-04 & 68,37 & ND & 33,00 & 1,10 & 35,00 & 21,50 \\
\hline PM-05 & 212,34 & ND & 1,13 & 25,10 & 103,64 & 34,00 \\
\hline PM-06 & $\mathrm{N}$ & $N$ & $\mathrm{~N}$ & $N$ & $N$ & $N$ \\
\hline PM-07 & 283,00 & $2,464,46$ & 85,10 & 0,17 & 184,35 & 92,42 \\
\hline PM-08 & $\mathrm{N}$ & $N$ & $N$ & $N$ & $N$ & $N$ \\
\hline PM-09 & 45,50 & ND & 32,25 & 0,26 & 22,00 & 42,50 \\
\hline PM-10 & ND & ND & 0,02 & ND & ND & 0,24 \\
\hline PM-11 & 5,00 & 19,00 & 0,13 & ND & 0,10 & 0,22 \\
\hline PM-12 & ND & 13,25 & ND & ND & ND & ND \\
\hline$P M-13$ & 2,75 & 16,50 & ND & ND & 0,60 & ND \\
\hline PM-14 & 45,75 & 65,97 & 0,10 & 0,14 & 43,72 & 10,50 \\
\hline PM-15 & 5,00 & 7,00 & ND & ND & 8,75 & 1,75 \\
\hline PM-16 & ND & 6,25 & 0,33 & ND & 0,66 & 0,91 \\
\hline PM-17 & ND & ND & ND & ND & 1,00 & 0,45 \\
\hline PM-18 & 1,15 & 42,50 & ND & ND & 2,55 & 0,29 \\
\hline PM-19 & ND & 20,60 & ND & ND & 2,50 & 0,77 \\
\hline PM-20 & $\mathrm{N}$ & $N$ & $\mathrm{~N}$ & $N$ & $\mathrm{~N}$ & $N$ \\
\hline PM-21 & 35,00 & 77,66 & 0,10 & 0,42 & 11,25 & 1,67 \\
\hline PM-22 & 9,50 & 23,75 & ND & ND & 1,46 & 0,55 \\
\hline PM-23 & 9,25 & 28,75 & ND & ND & 0,97 & 0,73 \\
\hline PM-24 & 6,25 & 48,25 & ND & ND & 2,29 & 0,68 \\
\hline PM-25 & $N$ & $\mathrm{~N}$ & $N$ & $\mathrm{~N}$ & $\mathrm{~N}$ & $N$ \\
\hline PM-26 & 31,25 & 114,40 & ND & ND & 9,50 & 1,18 \\
\hline PM-27 & 2,13 & 145,64 & ND & ND & 2,70 & ND \\
\hline PM-28 & 2,28 & 146,75 & ND & ND & 2,75 & ND \\
\hline PM-29 & $N$ & $\mathrm{~N}$ & $\mathrm{~N}$ & $\mathrm{~N}$ & $\mathrm{~N}$ & $N$ \\
\hline PM-30 & ND & ND & ND & ND & $\mathrm{ND}$ & ND \\
\hline PM-31 & 281,64 & $3.415,19$ & 22,91 & 82,75 & 140,00 & 34,79 \\
\hline PM-32 & ND & ND & 0,87 & ND & 2,53 & 25,50 \\
\hline PM-33 & ND & ND & 0,03 & ND & 33,50 & 50,80 \\
\hline
\end{tabular}


Resultados das Análises. Concentrações de Organoclorados em $\mu \mathrm{g} / \mathrm{L}$

Segundo Evento de Amostragem.

\begin{tabular}{|c|c|c|c|c|c|c|}
\hline \multirow[b]{2}{*}{ Amostra } & \multicolumn{6}{|c|}{10 de dezembro de 1997} \\
\hline & Clorofórmio & $\begin{array}{c}1,2- \\
\text { Dicloro } \\
\text { Etano }\end{array}$ & $\begin{array}{c}1,1,1- \\
\text { Tricloro- } \\
\text { Etano }\end{array}$ & $\begin{array}{c}\text { Tetracloreto de } \\
\text { Carbono }\end{array}$ & $\begin{array}{l}\text { Tricloro - } \\
\text { Etileno }\end{array}$ & $\begin{array}{c}\text { Tetracloro - } \\
\text { Etileno }\end{array}$ \\
\hline PM-01 & ND & 19,20 & ND & ND & 1,70 & 2,10 \\
\hline PM-02 & ND & 209,10 & ND & ND & 9,80 & 1,70 \\
\hline PM-03 & ND & ND & 18,50 & ND & 6,20 & 9,70 \\
\hline PM-04 & ND & ND & 24,60 & ND & 9,90 & 15,60 \\
\hline PM-05 & 210,70 & ND & 7,70 & 65,10 & 173,60 & 106,30 \\
\hline PM-06 & 352,30 & ND & 190,50 & ND & 311,50 & 214,00 \\
\hline PM-07 & 307,90 & ND & 165,30 & ND & 287,40 & 206,90 \\
\hline PM-08 & ND & 74,80 & ND & $\mathrm{ND}$ & ND & ND \\
\hline PM-09 & ND & ND & ND & ND & ND & ND \\
\hline$P M-10$ & $\mathrm{~N}$ & $N$ & $N$ & $N$ & $N$ & $N$ \\
\hline$P M-11$ & ND & ND & 65,10 & 1,30 & 42,50 & 93,60 \\
\hline$P M-12$ & ND & 14,30 & ND & ND & 5,10 & 3,60 \\
\hline PM-13 & ND & ND & 2,80 & ND & 3,00 & 8,50 \\
\hline PM-14 & ND & 330,60 & ND & ND & 86,50 & 34,90 \\
\hline PM-15 & ND & 128,70 & ND & 1,20 & ND & 1,60 \\
\hline PM-16 & ND & 210,30 & 6,20 & ND & 16,00 & 12,80 \\
\hline $\mathrm{PM}-17$ & ND & 95,90 & ND & ND & 1,70 & ND \\
\hline PM-18 & ND & 412,60 & ND & ND & 17,50 & 3,00 \\
\hline PM-19 & ND & 334,40 & ND & ND & 9,10 & ND \\
\hline PM-20 & ND & 690,30 & ND & ND & 23,20 & 5,00 \\
\hline PM-21 & ND & 59,00 & ND & ND & 20,40 & 10,50 \\
\hline PM-22 & ND & 187,70 & ND & ND & 4,00 & ND \\
\hline PM-23 & ND & 281,80 & ND & ND & 8,30 & 2,10 \\
\hline$P M-24$ & $N$ & $N$ & $N$ & $N$ & $\mathrm{~N}$ & $N$ \\
\hline PM-25 & ND & 298,60 & ND & ND & 30,80 & 12,40 \\
\hline PM-26 & ND & 202,60 & ND & ND & 5,50 & 2,40 \\
\hline PM-27 & ND & ND & ND & ND & ND & ND \\
\hline PM-28 & ND & $1.258,00$ & ND & ND & 12,20 & 1,80 \\
\hline PM-29 & ND & ND & ND & ND & ND & ND \\
\hline PM-30 & ND & ND & ND & ND & ND & 1,50 \\
\hline PM-31 & ND & 14,70 & ND & ND & ND & ND \\
\hline PM-32 & ND & ND & 3,20 & ND & 9,00 & 66,00 \\
\hline PM-33 & ND & ND & 1,30 & ND & 147,70 & 225,40 \\
\hline
\end{tabular}


Resultados das Análises. Concentrações de Organociorados em $\mu \mathrm{g} / \mathrm{L}$

Terceiro Evento de Amostragem.

\begin{tabular}{|c|c|c|c|c|c|c|}
\hline \multirow[b]{2}{*}{ Amostra } & \multicolumn{6}{|c|}{16 de maio de 1998} \\
\hline & Clorofórmio & $\begin{array}{c}1,2- \\
\text { Dicloro } \\
\text { Etano }\end{array}$ & $\begin{array}{c}1,1,1- \\
\text { Tricloro- } \\
\text { Etano }\end{array}$ & $\begin{array}{l}\text { Tetracloreto de } \\
\text { Carbono }\end{array}$ & $\begin{array}{c}\text { Tricloro - } \\
\text { Etileno }\end{array}$ & $\begin{array}{c}\text { Tetracioro - } \\
\text { Etileno }\end{array}$ \\
\hline PM-01 & 13,50 & 241,80 & 1,60 & ND & 11,10 & 2,80 \\
\hline PM-02 & 6,70 & 98,40 & ND & ND & 5,10 & 1,30 \\
\hline PM-03 & 10,20 & 18,30 & 10,40 & ND & 6,80 & 9,10 \\
\hline PM-04 & 23,50 & 26,90 & 23,50 & 4,50 & 31,20 & 33,00 \\
\hline PM-05 & 267,90 & 564,70 & 7,50 & 38,10 & 372,30 & 176,70 \\
\hline PM-06 & $N$ & $N$ & $N$ & $N$ & $\mathrm{~N}$ & $N$ \\
\hline PM-07 & 429,50 & $1.563,40$ & 257,90 & ND & 750,30 & 395,30 \\
\hline PM-08 & ND & 34,00 & ND & ND & 3,30 & ND \\
\hline PM-09 & 21,80 & 31,90 & 50,20 & ND & 30,80 & 85,90 \\
\hline PM-10 & $N$ & $N$ & $N$ & $N$ & $\mathrm{~N}$ & $N$ \\
\hline$P M-11$ & 2,40 & 21,40 & 1,00 & ND & 3,80 & 1,60 \\
\hline$P M-12$ & $\mathrm{~N}$ & $N$ & $N$ & $N$ & $\mathrm{~N}$ & $N$ \\
\hline$P M-13$ & ND & 16,50 & ND & ND & ND & ND \\
\hline PM-14 & $N$ & $N$ & $\mathrm{~N}$ & $\mathrm{~N}$ & $N$ & $N$ \\
\hline PM-15 & 5,30 & 23,70 & ND & ND & 15,00 & 6,00 \\
\hline PM-16 & 20,20 & 37,40 & 4,00 & ND & 23,50 & 12,40 \\
\hline PM-17 & 2,00 & 18,50 & ND & ND & ND & ND \\
\hline PM-18 & ND & 62,10 & ND & ND & 4,10 & 1,40 \\
\hline PM-19 & ND & 108,40 & ND & ND & 6,80 & 1,90 \\
\hline PM-20 & $\mathrm{N}$ & $\mathrm{N}$ & $\mathrm{N}$ & $N$ & $N$ & $\mathrm{~N}$ \\
\hline PM-21 & $\mathrm{N}$ & $\mathrm{N}$ & $\mathrm{N}$ & $N$ & $\mathrm{~N}$ & $N$ \\
\hline PM-22 & 8,90 & 95,50 & ND & ND & 5,10 & 1,70 \\
\hline PM-23 & 5,90 & 70,40 & ND & ND & 3,90 & 2,40 \\
\hline PM-24 & $\mathrm{N}$ & $\mathrm{N}$ & $N$ & $\mathrm{~N}$ & $N$ & $\mathrm{~N}$ \\
\hline PM-25 & $\mathrm{N}$ & $\mathrm{N}$ & $\mathrm{N}$ & $\mathrm{N}$ & $N$ & $N$ \\
\hline PM-26 & $N$ & $N$ & $\mathrm{~N}$ & $N$ & $\mathrm{~N}$ & $\mathrm{~N}$ \\
\hline PM-27 & 1,00 & ND & ND & ND & ND & ND \\
\hline PM-28 & ND & 326,90 & ND & ND & 2,90 & ND \\
\hline PM-29 & $\mathrm{N}$ & $\mathrm{N}$ & $\mathrm{N}$ & $\mathrm{N}$ & $N$ & $N$ \\
\hline PM-30 & ND & $N D$ & ND & ND & ND & ND \\
\hline PM-31 & 2,70 & ND & ND & ND & ND & ND \\
\hline PM-32 & 1,60 & 11,50 & 1,60 & ND & 5,60 & 56,10 \\
\hline PM-33 & 1,50 & 11,80 & ND & ND & 192,70 & 345,00 \\
\hline
\end{tabular}




\section{APÊNDICE 06}

\section{Análises Químicas para Determinação de Benzeno, Tolueno e Xilenos em Amostras dos Tambores}


Resultados das Análises (Tambores).

Concentrações de BTX em $\mu \mathrm{g} / \mathrm{L}$

\begin{tabular}{|c|c|c|c|c|c|c|}
\hline & \multicolumn{2}{|c|}{ Primeira Bateria (novembro/ 1997) } & \multicolumn{3}{|c|}{ Segunda Bateria (maio/ 1998) } \\
\hline Amostra & Benzeno & Tolueno & Xilenos & Benzeno & Tolueno & Xilenos \\
\hline T-01 & ND & ND & ND & - & - & - \\
\hline T-02 & ND & ND & ND & - & - & - \\
\hline T-03 & - & - & - & - & - & - \\
\hline$T-04$ & ND & ND & ND & ND & ND & ND \\
\hline T-05 & ND & ND & ND & ND & ND & ND \\
\hline T-06 & ND & ND & ND & - & - & - \\
\hline$T-07$ & ND & ND & ND & - & - & - \\
\hline
\end{tabular}




\section{APÊNDICE 07}

\section{Análises Químicas para Determinação de Compostos Organoclorados em Amostras dos Tambores}


Resultados das Análises. Concentrações de Organoclorados em $\mu \mathrm{g} / \mathrm{L}$

Primeira Bateria de Tambores

\begin{tabular}{|c|c|c|c|c|c|c|}
\hline & \multicolumn{5}{|c|}{ Primeira Bateria (novembro/ 1997) } \\
\cline { 2 - 8 } Amostra & Clorofórmio & $\begin{array}{c}1,2- \\
\text { Dicloro } \\
\text { Etano }\end{array}$ & $\begin{array}{c}1,1,1- \\
\text { Tricloro- } \\
\text { Etano }\end{array}$ & $\begin{array}{c}\text { Tetracloreto } \\
\text { de Carbono }\end{array}$ & $\begin{array}{c}\text { Tricloro - } \\
\text { Etileno }\end{array}$ & $\begin{array}{c}\text { Tetracloro - } \\
\text { Etileno }\end{array}$ \\
\hline T-01 & ND & ND & ND & ND & ND & ND \\
\hline T-02 & ND & ND & ND & ND & ND & ND \\
\hline T-03 & - & - & - & - & - & - \\
\hline T-04 & ND & ND & ND & ND & ND & ND \\
\hline T-05 & ND & ND & ND & ND & ND & ND \\
\hline T-06 & ND & ND & ND & ND & ND & ND \\
\hline T-07 & ND & ND & ND & ND & ND & ND \\
\hline
\end{tabular}

Resultados das Análises. Concentraçōes de Organoclorados em $\mu \mathrm{g} / \mathrm{L}$.

Segunda Bateria de Tambores

\begin{tabular}{|c|c|c|c|c|c|c|}
\hline & \multicolumn{6}{|c|}{ Segunda Bateria (maio/ 1998) } \\
\hline Amostra & Clorofórmio & $\begin{array}{c}1,2- \\
\text { Dicloro } \\
\text { Etano }\end{array}$ & $\begin{array}{c}1,1,1- \\
\text { Tricloro- } \\
\text { Etano }\end{array}$ & $\begin{array}{c}\text { Tetracloreto } \\
\text { de Carbono }\end{array}$ & $\begin{array}{c}\text { Tricloro - } \\
\text { Etileno }\end{array}$ & $\begin{array}{c}\text { Tetracloro } \\
- \text { Etileno }\end{array}$ \\
\hline T-01 & - & - & - & - & - & - \\
\hline T-02 & - & - & - & - & - & - \\
\hline T-03 & - & - & - & - & - & - \\
\hline T-04 & ND & ND & ND & ND & ND & ND \\
\hline T-05 & ND & ND & ND & ND & ND & ND \\
\hline T-06 & - & - & - & - & - & - \\
\hline T-07 & - & - & - & - & - & - \\
\hline
\end{tabular}

